\title{
Exploring Mexican Hybrid Baroque: New Perspectives on Colonial Architectural Sculpture
}

\author{
by \\ Maxine Compean \\ A thesis submitted to the Faculty of Graduate and Postdoctoral Affairs in partial \\ fulfillment of the requirements for the degree of \\ Master \\ in \\ Art History \\ Carleton University \\ Ottawa, Ontario \\ (C) 2015 \\ Maxine Compean
}




\section{ABSTRACT}

My research aims to challenge existing notions of cross-cultural histories during the early modern era. This thesis will speak to an alternative analysis of the cultural consequences of colonialism and how Indigenous and Mestizo styles that emerged in Mexico had a global cultural impact. During the 17th and 18th centuries, Mestizo and Indigenous architects and sculptors succeeded in creating

a different artistic product from the Spanish Baroque that enabled them to represent Christian symbols in their own way. In turn, while the Spanish conqueror was physically and intellectually removed from current European artistic developments, he was visually drawn by Tequitqui architecture because it was not only a new style but it also exuded a different identity. Through the analysis of written testimonies by Spanish friars, historians and architects it is evident that the result of cultural hybridity made an impression on the European's visual culture.

After close observation it became evident that the discussion of Tequitqui art, especially regarding Indigenous and Mestizo artist's recognition, is often neglected in art history books. Most literature covers the usual discourse of Spain shaping Mexican culture due to colonialism, but the opposite discussion is nonexistent. Therefore this study aims to challenge the Western discourse and 
propose that the cosmopolitanism of Tequitqui art and the artists who created it deserve acknowledgment in the literature of Baroque art history. 


\section{ACKNOWLEDGEMENTS}

I would like to express my most sincere gratitude to Professors Stéphane Roy and Mariana Esponda for supervising my thesis and providing me with invaluable feedback. Emma Hamilton-Hobbs also deserves recognition for editing my work. I also want to thank the Faculty of Graduate and Post Doctoral Affairs for their monetary support that enabled me to do research in Mexico. My mother deserves special acknowledgement since she provided transportation while I was researching in Mexico and valuable help and high definition photographs while I was in Canada. Isabel Cervantes Tovar was intrinsic to this project as she pointed me in the right direction for resources and primary sources in Mexico. Additionally I would like to give thanks to Professor and Architect Xavier Cortés Rocha who supported my thesis by personally providing me with his own knowledge of the Tequitqui style Mexico-wide. I trust that the success of this project rests on these individuals and scholars who believe in me and in my initiatives. 


\section{TABLE OF CONTENTS}

1. Title Page

2. Abstract

4. Acknowledgements

5. Table of Contents

6. List of Illustrations

8. Introduction

14. Chapter One:

Reassessing Terms: Giving Meaning to Art Through Language

37. Chapter Two:

Mexican Baroque: Artist Training and Expression of Identity

49. Chapter Three:

The Visual Affects of Mexican Hybrid Baroque Architecture and Sculpture

65. Conclusion:

Revisiting Mexican Hybrid Baroque Art History and its Global Impact

77. Appendix One:

Illustrations

116. Appendix Two:

Translations

119. Bibliography 


\title{
LIST OF ILLUSTRATIONS
}

\author{
INTRODUCTION
}

[Fig. 1.1 Paintings by Miguel Cabrera in Church of Santa Rosa, Querétaro, 18th Century]

\section{CHAPTER ONE}

[Fig. 2.1 Venus of Willendorf, ca.30,000 BCE]

[Fig. 2.2 Universidad de Salamanca, Spain]

[Fig. 2.3 Ayuntamiento de Sevilla, Spain]

[Fig. 2.4 Convento de San Esteban, Salamanca]

[Fig. 2.5 Detail of the Retablo del Perdón in the Metropolitan Cathedral of Mexico City]

[Fig. 2.6 Sagrario Metropolitano, Mexico City]

[Fig. 2.7 Cacaxtla Mural, Tlaxcala]

[Fig. 2.8 Hospital of Acámbaro, Guanajuato, Mexico]

[Fig. 2.9 Temple of Santa Mónica, Hidalgo, Mexico]

[Fig. 2.10 Façade of Santa María Tonantzintla, Puebla, Mexico]

[Fig. 2.11 Interior of Santa María Tonantzintla, Puebla, Mexico]

[Fig. 2.12 Detail of the interior of Santa María Tonantzintla, Puebla, Mexico]

[Fig. 2.13 Aztec stone carving]

[Fig. 2.14 Aztec stone polychrome sculpture]

[Fig. 2.15 Aztec stone sculpture of God Xochipilli]

[Fig. 2.16 Aztec stone sculpture of God Tláloc]

[Fig. 2.17 Interior of Capilla del Rosario, Puebla]

[Fig. 2.18 Façade of Santuario de Ocotlán, Tlaxcala]

\section{CHAPTER TWO}

[Fig. 3.1 Jerónimo de Balbás, Retablo de los Reyes, 18th Century]

[Fig. 3.2 Jerónimo de Balbás, Retablo del Perdón, 18th Century]

[Fig. 3.3 Interior of the Church of Santa Clara, Querétaro, Mexico]

[Fig. 3.4 Detail of the Courtyard at Convent of San Agustín, Querétaro, Mexico]

[Fig. 3.5 Detail of a retablo inside the Church of Santa Clara, Querétaro, Mexico]

[Fig. 3.6 Detail of a retablo inside the Church of Santa Clara, Querétaro, Mexico]

[Fig. 3.7 Detail of a retablo inside the Church of Santa Rosa, Querétaro, Mexico]

[Fig. 3.8 Detail of the inside of Capilla del Rosario, Puebla, Mexico]

[Fig. 3.9 Detail of the Stone of Moctezuma I in the National Anthropology Museum of Mexico City]

[Fig. 3.10 Detail of the inside of Santa María Tonantzintla, Puebla, Mexico]

[Fig. 3.11 Detail of the inside of Capilla del Rosario, Puebla, Mexico] 
[Fig. 3.12 Detail of table inside the Camarín at Santuario de Ocotlán, Tlaxcala, Mexico]

[Fig. 3.13 Detail of the inside of Santa María Tonantzintla, Puebla, Mexico]

[Fig. 3.14 Stone sculpture from the Archeological Site of Teotihuacán, Mexico]

[Fig. 3.15 Image of an Indigenous man preparing feathers to decorate]

\section{CHAPTER THREE}

[Fig. 4.1 Pueblan Ceramic]

[Fig. 4.2 Detail of the inside of Capilla del Rosario, Puebla, Mexico]

[Fig. 4.3 Detail of the inside of Capilla del Rosario, Puebla, Mexico]

[Fig. 4.4 Detail of the inside of Capilla del Rosario, Puebla, Mexico]

[Fig. 4.5 Ocote tree]

[Fig. 4.6 Image of the Virgin of Ocotlán]

[Fig. 4.7 Title page of Manuel de Loayzaga's book]

[Fig. 4.8 Francisco Miguel Tlayoltehuanitzi, Detail of the Camarín inside the Santuario de Ocotlán, Tlaxcala, Mexico]

[Fig. 4.9 Francisco Miguel Tlayoltehuanitzi, Detail of the Camarín inside the Santuario de Ocotlán, Tlaxcala, Mexico]

[Fig. 4.10 Francisco Miguel Tlayoltehuanitzi, Detail of the Dome in the Camarín]

[Fig. 4.11 Francisco Miguel Tlayoltehuanitzi, Wooden table inside the Camarín]

[Fig. 4.12 Aztec stone sculpture of a monkey]

[Fig. 4.13 Reproduction of one wooden bench outside the Camarín]

[Fig. 4.14 Francisco Miguel Tlayoltehuanitzi, Detail of wooden bench]

[Fig. 4.15 Francisco Miguel Tlayoltehuanitzi, Detail of wooden bench]

[Fig. 4.16 Detail of the inside of Santa María Tonantzintla, Puebla, Mexico] 


\section{INTRODUCTION}

Globalization is deeply rooted in the colonial period as it engendered crossroads for many cultural, political and religious exchanges. Throughout this thesis, I aim to challenge existing notions of cross-cultural histories during the early modern era. The three chapters that encompass this project will provide an alternative analysis of the cultural impact of colonialism and how Indigenous and Mestizo $^{1}$ styles that emerged in Mexico had a global cultural impact. During the 17th and 18th centuries, Mestizo and Indigenous architects and sculptors succeeded in creating a different artistic product from the Spanish Baroque that enabled them to represent Christian symbols in their own way. In turn, while the Spanish viewer was physically and intellectually removed from current European artistic developments, they were visually drawn to Tequitqui ${ }^{2}$ architecture because it presented a new style and different identity. Through the analysis of written testimonies by Spanish friars, historians and architects, I will demonstrate how cultural production resulting from this cultural hybridity made an impression on European visual culture.

\footnotetext{
${ }^{1}$ Mestizo is a term that describes someone of mixed European and Indigenous descent.

2 Tequitqui denotes the fusion of two different cultural aesthetics, Indigenous and Spanish, in architectural sculpture. This term will be investigated in further detail in chapter one.
} 
Upon a close inspection of Mexican colonial architecture and sculpture it became clear that the study of the Baroque period requires further exploration. The work of Martha Fernández, Elisa Vargaslugo, Guillermo Tovar y Teresa, Jorge Alberto Manrique, José Moreno Villa and Constantino Reyes-Valerio, among other scholars, have contributed to the substantial knowledge on 17th and 18th century Mexican art. This project is different in that it explores to the study of the hybrid style that emerged during the 16th century and one that, as I claim in this thesis, continues to develop during the 17 th and 18 th centuries. Therefore the investigation that takes place in this thesis encompasses sculpture and architecture during the 17th-and-18th centuries in Mexico. Since casta and religious paintings have already been explored in great depths, my focus will be on sculpture found within many types of ecclesiastical architecture [Figure 1.1].

The first chapter will address the issue of terminology. The description of non-Western art in terms that describe Western art becomes problematic and complicates the art history of Mexico. In this chapter I will explain how this occurred in Mexico and will provide relevant examples to support this argument. Terms that describe Western art exclude aesthetics resulting from crosspollination and hybridity. Art historians need to acknowledge that terms used to describe non-Western art affect its meaning of it and how it is perceived. The use of alternative terminology that makes specific reference to non-Western art aims 
to be beneficial to its context and history. The purpose of using different terms is to avoid the risk of describing the aesthetic of a non-Western art object with Western words and understand it in terms that contextualize the non-Western art object in question. In other words, by stripping non-Western art from Western terminology and using alternative words, one can work towards the decolonization of the language used to describe non-Western art. Additionally, because globalization in art is an inevitable theme during the 18th century, a discussion on the global exchange of ideas between Mexico and Spain will be included in this chapter. There will also be a discussion of the controversial term Mestizo to demonstrate the importance of the careful selection of words to speak about art while writing art history (i.e. creating knowledge). I propose to re-use the term Tequitqui to refer to the hybrid artistic style created in Mexico that other scholars also utilize in their investigations of Mexican architecture and sculpture. However, while scholars such as Martha Fernández claim this term should only be used for hybrid stone sculpture during the 16th century, I argue that we should continue to implement this term into the 17th and 18th centuries.

Although it might seem paradoxical, the best way to understand hybridity is to establish formal and visual distinctions between Spanish and Mexican Baroque. One of the main arguments made in this thesis is that Mexican and Spanish Baroque ought to be distinguished. To begin this differentiation we need 
to recognize the hand and identity of the artist. The art object and the artist are theoretically inseparable and thus the product of an artist's practice reflects the development of his/her identity, especially in colonial Mexico, is critical to the conception and study of its visual culture. The second chapter of this thesis will delineate the stylistic differences between the Spanish Baroque and Mexican Baroque with examples that include churches, monasteries and chapels. This chapter will emphasize the important impact of the Mexican hybrid style on European visual culture. Since the 16th century, Spanish friars, historians and architects declared that they found Mexican hybrid style to be outstanding and evidently different from European art and architecture. These testimonies prove that Indigenous and Mestizo artists were able to create a style that had a strong visual affect on the Spanish audience. Did the Spanish audience take what they saw in Mexico and apply it in Spain? How would this impact the way we explain the cultural consequences of colonialism? These are questions I address in my research.

The third chapter analyzes non-Mexican perceptions of the Indigenous and Mestizo styles. Because Mexico City was the main artistic center where Spanish architects flourished exclusively, this city will not be included in this thesis as a center of Tequitqui art, but rather as a center of Spanish Baroque art in Mexico. In the interest of demonstrating that artists produced hybrid Baroque creations 
outside the main artistic center, I will discuss cities in central Mexico such as Querétaro, Puebla and Tlaxcala, which were influential to other surrounding towns. Testimonies written by prominent 16 th-and-17th century individuals will not only elucidate the strong difference that exists between Mexican and Spanish Baroque styles, but they serve as testament of the visual impact Mexican hybrid style had on Europeans. In 1671 bishop Juan de Palafox y Mendoza wrote Virtudes del Indio defending the rights of the Indigenous population in Mexico. In his treatise, Palafox y Mendoza saw that the rights of the Indigenous people were respected. He acknowledged their customs, hard work and devotion to the Christian church. Palafox y Mendoza is recognized as a defender of the Indigenous as he intended to demonstrate that the Indigenous people are good by nature. He implores that the King of Spain learn from his experiences with the Indigenous people to make better laws that would be efficient for this population. ${ }^{3}$ His life and work are relevant to this project because he reacted visually to the work produced by Indigenous artists in Puebla.

Not far from the state of Puebla is Tlaxcala, one of the smallest states in Mexico. During the 18th century an Indigenous artist decorated the Santuario de Ocotlán in this small town. The friar, Manuel de Loayzaga, who oversaw most of

3 Michael Richard Scott, "Palafox y Mendoza's Virtudes del Indio as a Deliberative Oration" (MA thesis, University of North Carolina at Chapel Hill, 2011), 1-2. 
the construction and decoration of this Sanctuary wrote in the most colorful words about Francisco Miguel and his art. The originality of his design and execution will be widely examined throughout the third chapter. Drawing from these two case studies I explain the impact of Mexican hybrid art on the Spanish audience and why it is evident that the inclusion and recognition of Mexican Indigenous artists in art history books has been neglected. Most literature covers the usual discourse of Spain shaping Mexican culture due to colonialism, but the opposite discussion is nonexistent. This study aims to challenge the Western art history canon to propose a transcultural exchange where Tequitqui art and the artists who created it deserve acknowledgment in the literature of Baroque art history. 


\section{Chapter One}

\section{Reassessing Terms: Giving Meaning to Art Through Language}

The use of language is frequently discussed in museology and curatorship. Shaping knowledge and providing meaning while telling a visual narrative are common preoccupations in this field. Labeling is an intrinsic component of installing art exhibitions. These are the carefully composed bits of written language that provide context and information about an artwork to the gallery visitor. Meaning is also given to exhibitions through the specific placement of artworks. Moreover, sponsors might affect the meaning assigned to the exhibition's main theme. These are all common concerns that curators and exhibition makers must consider before displaying a show to the public. Although it is understood that the careful use of language in curatorship is of utmost importance, in Art history, a limited literature on this phenomenon is available. In "Aesthetics and pre-Columbian Art," Columbia University professor Esther Pasztory discusses the problematic use of Western aesthetic language to understand pre-Columbian art. Pasztory states "[b]efore attempting a reconstruction of the pre-Columbian concept of art, it is useful to note how the West had come to see it as "art" and how it has been fitted into Western schemas of aesthetics." 4 Before pre-Columbian art objects were understood as art, in the

\footnotetext{
4 Esther Pasztory, "Aesthetics and Pre-Columbian Art," RES 29/30 (1996): 320.
} 
Western sense, they were considered curiosities due to the fact that the Art history of this part of the world did not develop in the same Western evolutionary paradigm. ${ }^{5}$ Pasztory acknowledges that Westerners misunderstood non-Western art because they forced their own categorizations of art onto a culture that did not evolve in the same way. Therefore, in an attempt to demonstrate how language complicates the meaning, context and our understanding of art, this chapter will include a commentary on the predicament of art labeling.

We can retrace our steps to prehistory and investigate the issue of labeling by reconsidering the name given to an art object. During an archeological dig in Austria, workers found a portable figurine that dates back to the 30,000BCE. This small stone figurine was named Venus of Willendorf [Figure 2.1]. Here we encounter a nomenclature conflict. The language chosen to name this art object describes a goddess and a place extraneous to the art object itself. Venus, a Roman version of the Greek mythological goddess of love, beauty, prosperity and fertility was conceived thousands of years after the creation of the Paleolithic figurine. A similar blunder occurs to her attribution to Willendorf. It was found in this Austrian town, but it does not confirm that she was conceived there. Reconsidering the name given to this prehistoric art object unveils the unattended predicament of labeling. Naming gives meaning and context to art

5 Pasztory, "Aesthetics and Pre-Columbian Art," 320-322. 
objects and, in this case, this language can create mistaken ideas of her origins and decontextualize the art object itself.

Similarly to what happened to the Venus of Willendorf, there were many lacunas in Mexican art history that need further investigation. For example while perusing in a few art museums the exclusion of historic non-European artist names on labels seemed peculiar. Another major observation is the problematic labeling of Mexican Baroque architecture using Spanish terminology. These peculiarities create a problem in the way viewers and scholars conceptualize Mexican Baroque architecture. Breaking the tendency to describe Mexican architecture in European terms could lead to decolonizing the language used to describe non-Western art, and could also result in the creation of alternative terms to describe the authenticity of non-Western art. To begin this discussion it is necessary to establish a discourse on labeling and terminology that will provide alternatives to the language used in writing non-Western Art History.

There are three main points regarding labeling that are important to emphasize regarding labeling Mexican Baroque architecture and sculpture during the 17th and 18th centuries. At the outset it is crucial to understand and differentiate the stylistic qualities of Spanish Baroque versus those of Mexican Baroque. Secondly, it is pertinent to introduce some arguments for and against 
the use of the term Mestizo to describe aesthetic qualities of an artwork. Finally, the term Tequitqui will be defined and re-evaluated as it is one of the only nonWestern term used to describe the hybrid style conceived by Mexicans in the last two centuries of Spanish colonialism. Throughout this project the term 'hybrid' or 'hybridity' will be used as a framework that encompasses the result of transculturation as an opportunity for subaltern cultures to become empowered by change. ${ }^{6}$ Therefore, hybridity includes discussions of new identities and the product of new artistic expressions as a result of cross-cultural encounters.

To initiate the discussion of Mexican and Spanish Baroque architecture and sculpture, it is imperative to bear in mind the language used to refer to it in existing literature. "Baroque" is a term that aims to categorize works of art created in certain styles within the 17 th and 18 th centuries, although the term itself did not come into existence until later. In 1981 Guillermo Tovar y Teresa defined the Baroque as "a compound of attitudes and artistic manifestations in the West."7 Spanish Baroque architecture was modeled on many different stylistic influences, including Moorish aesthetic, Gothic expression and other European

\footnotetext{
${ }^{6}$ Marwan M. Kraidy, Hybridity, or the Cultural Logic of Globalization, (Philadelphia: Temple University Press, 2005), 151.

${ }^{7}$ Xavier Cortés Rocha, El Clasicismo en la Arquitectura Mexicana, 1524-1784, (México: Miguel Ángel Porrúa, 2007), 24 (My own translation, see appendix 1 for original text).
} 
artistic techniques. ${ }^{8}$ Particular terminology is used to categorize variations in Spanish Baroque architecture.

Two terms that reoccur in the discussion of Spanish Baroque architecture and in Mexican Baroque, are Plateresque ${ }^{9}$ and Churrigueresque. ${ }^{10}$ Plateresque is a term that describes a Renaissance Spanish style that "appeared when Italian Renaissance ideas interacted with the Late Gothic Isabelino style."11 Architecture in the Plateresque style consists of heavy decoration on arches, columns, pilasters and jambs, it also incorporated balustrade columns, ironwork and woodwork. Visually it seems to contain elements of the Gothic period and is also a hybrid product from the blending of Moorish and Spanish cultures (mudéjar). ${ }^{12}$ Although the Plateresque flourished during the Renaissance, there are examples of this style in later centuries. A few examples of Plateresque architecture are the façade of Salamanca University (Spain) [Figure 2.2] and the façade of the Ayuntamiento

\footnotetext{
8 Werner Weisbach, Spanish Baroque Art: Three Lectures Delivered at the University of London (Cambridge: University Press, 1941), 13-19.

${ }_{9}^{9}$ Plateresque comes from the word 'plata' which means silver in English. It speaks to a Renaissance type of sculptural decoration that appears like silverwork. ${ }^{10}$ Churrigueresque is a word that originates from Madrilenian (from Madrid, Spain) architect José de Churriguera's last name. It is allegedly a style of Spanish Baroque sculptural decoration that he invented, however he did not coin this term.

${ }^{11}$ José Manuel Aguilar Moreno, "Tequitqui Art of the 16th-Century Mexico: An Expression of Transculturation" (PhD Dissertation, University of Texas, 1999), 102.

${ }^{12}$ Cortés Rocha, El Clasicismo en la Arquitectura Mexicana, 21.
} 
de Sevilla in the San Francisco Quarter (Spain) [Figure 2.3]. Among the many terms used to refer to Spanish Baroque architecture is Churrigueresque. This ornamental architectural style has five important characteristics: it is mostly seen in retablos, ${ }^{13}$ it is usually gold, heavily decorated, employs salomonic columns and estípites $^{14}$ [Figure 2.4]. ${ }^{15}$ Spanish Churrigueresque moves away from Classical logic in order to alter proportions and "[attack] the basic principle of all structure." 16 The vast majority of the space is overpowered by decoration that hides all architectural structure elements (i.e. walls, pilasters and columns) [Figure 2.5]. This image reveals that the retablo covers the original architectural structure of the cathedral. Parts of the ceiling, windows and walls are concealed behind this golden structure.

The Spanish Baroque style is the cross-cultural result of blended styles and a variety of different aesthetics to create a new artistic product. Therefore it is no surprise that this style also appeared across the Spanish colonies. In Mexico it is effortless to recognize the Spanish Baroque legacy, especially in Mexico City [Figure 2.6]. An evident example is the façade of the Sagrario Metropolitano, one

${ }^{13}$ Retablos are large altarpieces that cover all internal structural elements of a church.

${ }^{14}$ Estípite is an inverted pilaster that is sometimes used for support in an architectural structure, but mostly for decorative purposes.

15 Manuel Toussaint, Colonial Art in Mexico (Austin: University of Texas Press, 1967), 213.

16 Ibid., 277. 
of countless instances of Spanish Baroque architecture in Mexico City. In the early modern era this city was known as a metropolis where innovation and archetypes developed to determine the historical course of Mexican art. Mexico City was also characterized by "the presence of a great number of artists and specialty studios; it had the capacity to export art and afford it reflecting the prosperous and complex existence of the art world [during the 18th century]..."17 It was also the center of educational institutions for artist formation and advancement. Every other city and town was considered as a periphery to this main artistic center. ${ }^{18}$ Many Spanish architects like Lorenzo Rodriguez, Pedro de Arrieta and Jerónimo de Balbás created large churches in the Spanish Baroque style in Mexico City. Thus this metropolis is the starting point of the problematic terminology used to describe Spanish Baroque also implemented to Mexican Baroque. In Mexico City our sight recognizes Spanish Baroque, although it is labeled Mexican Baroque. Labeling Spanish Baroque in Mexico City as Plateresque and Churrigueresque is not what appears problematic. The problem appears when these terms are applied to the hybrid styles developed outside of Mexico City by Indigenous and Mestizo artists, complicating one's understanding of Mexican Baroque architecture.

17 Thomas Dacosta Kauffman, "La Geografía Artística en América: El Legado de Kubler y sus Límites," Anales del Instituto de Investigaciones Estéticas de la Universidad Nacional Autónoma de México 21, no. 74-75 (1999): 20.

18 Ibid., 20. 
Prior to the Conquest, the Aztec culture dominated Mesoamerica, ${ }^{19}$ yet many other cultures flourished artistically. Cultures such as the Toltecs, Mixtecs and Maya produced art and architecture including pyramids, murals and stone carvings. An example of Aztec religious architecture was known as Teocallis, which were pyramids with shrines on top. ${ }^{20}$ Murals were found in many of these pre-Hispanic cities. They were colorful and contained complicated symbolisms [Fig.2.7]. The stone carvings were decorative relief sculptures that are often found on stone slabs of many sizes and shapes, sculptures and architecture [Fig. $2.13,3.9,2.15]$. These artistic techniques were carried over into the colonial era and fused with new religious idioms and symbolism. Aguilar Moreno believes that pre-Columbian and Mexican Hybrid art "cannot be judged with Greek-Roman European canons, because it comes from the sensibility of a very different vision of the world."21 The mixture of Indigenous traditional artistic skills, their understanding of religious symbols and their new identities resulted in a new hybrid product, one that we have come to understand as 'Mexican'.

Art historian and UNAM professor Elisa Vargaslugo describes Mexican Baroque as a style that attracts the senses through a different expression of its

\footnotetext{
${ }^{19}$ Aguilar Moreno, "Tequitqui Art in 16th-Century Mexico," 103.

20 Ibid., 103.

21 Ibid., 112.
} 
derivative European Baroque. She argues that Mexican Baroque has its own cosmopolitan personality as is the Indigenous population that conceived it. ${ }^{22}$ In Latin America, the Baroque, as an artistic attitude, did not develop as a result of the Christian Reformation and Counter-Reformation; instead it developed as a result of voluntary embrace. It was an attitude that the Indigenous populations were already performing. ${ }^{23}$ For example, as Aguilar Moreno argues, Aztec artists were already "transmitt[ing] religious and mythical concepts that legitimized the power of the state."24 In other words, through visual metaphors, they used art as a means of communication. ${ }^{25}$ In Europe, Baroque styles developed as a result of religious and political turmoil. Spanish architects and artists started to turn away from a classical approach to art to a rhetorical aesthetic where symbolic value trumped formal structure. Rather than following a classical or formal structure in art, Latin American architects were already comfortable with a symbolic approach to art. ${ }^{26}$ Nonetheless when scholars write about Mexican Baroque architecture they typically ascribe it with Spanish Baroque terminology. In 1954, historian Luis MacGregor describes the Mexican Indigenous stone carving technique as one similar to Moorish techniques and thus bestowing this mode of

${ }^{22}$ Elisa Vargaslugo, México Barroco (Querétaro: Gráficas Monte Albán, S.A. de C.V., 1992), 13-14.

23 Ibid., 83.

${ }^{24}$ Aguilar Moreno, "Tequitqui Art in 16th-Century Mexico," 103.

25 Ibid., 103.

${ }^{26}$ Vargaslugo, México Barroco, 83. 
decoration as Plateresque. ${ }^{27}$ Although the Indigenous style borrows from Spanish idioms, I believe that the use of Western language complicates the understanding of Indigenous Mexican architecture by borrowing a Western criterion to discuss a hybrid aesthetic. Two examples of this style that MacGregor refers to as Plateresque are the façade of Hospital of Acámbaro in Guanajuato [Figure 2.8] and the façade of the Temple of Santa Mónica in Hidalgo [Figure 2.9]. These, among many other examples of Indigenous architectural decoration during the 16th century, are also referred to as Tequitqui. It is worth noting that we have intersecting terms; one that quintessentially describes and refers to a Spanish mode of decoration implemented to an architectural decoration that is not Spanish in nature, and another term to describe the same mode of decoration. The use of the term Tequitqui, which encompasses hybrid architectural decoration, will be discussed in detail in subsequent pages.

It is common to encounter the term Churrigueresque to describe an architectural style that does not conform to the same norms as Spanish Churrigueresque. In the town of San Andrés Cholula (Puebla), for instance, the church of Santa María Tonantzintla stands as one of the best representative examples of Mexican Baroque architecture. Its façade and inside decoration are completely outside of the lines that bind Spanish Baroque architecture in Mexico

${ }^{27}$ Luis MacGregor, El Plateresco en México (México: Editorial Porrúa, 1954), 17. 
[Figures 2.10-2.11]. This church is unique in its expression, iconography and origins. It illustrates a heavenly scene that is a product of hybridity and thus its iconography differs from Spanish idioms and from purely Indigenous depictions. Author Luisa Ruiz Moreno, among many other scholars who study this church, extrapolates on its iconography. Tonantzin, the goddess of corn was venerated by the Aztecs as the protector of fruits and flowers that were allowed to flourish by Tláloc, the god of rain. Santa María Tonantzintla highlights the importance of these two deities through depictions of local flowers and fruits that allude to the Tlalocan, Tláloc's paradise heaven where Tonantzin was crowned. ${ }^{28}$ Also, it is believed by 21st-century locals that the church was built and funded by the Indigenous community, which was atypical for 17 th-century art commissions. Although the characteristics of this church are far from Spanish, in 1967 Toussaint describes this Mexican Baroque church as Churrigueresque. ${ }^{29}$ As outlined before, a main characteristic of Churrigueresque style was the prevalent use of gold. In Santa María Tonantzintla the use of gold is collateral to the outstanding application of colour [Figure 2.12]. There must be other terms to describe and provide meaning to this colorful and heavily decorated church. The use of Western terminology to characterize a non-Western art object or style,

\footnotetext{
${ }^{28}$ Luisa Ruiz Moreno, "Relatos Míticos en Torno a Tonantzintla," in Mirando al Paraíso, ed. Julio Glockner (Puebla: Benemérita Universidad Autónoma de Puebla, 1995), 96. (My own translation, see appendix 1 for original text)

${ }^{29}$ Toussaint, Colonial Art in Mexico, 206.
} 
especially in this case, seems to be an oversight. Alternative terms such as Tequitqui and Mexican Hybrid Baroque could be beneficial to describe this crosscultural style in a way that contextualizes its artists, their identity and history.

The colonial era witnessed the exchange and transformation of ideas across borders. According to University of California's 18th Century Literature Professor Felicity A. Nussbaum, globalization "...is the result of historical processes whose histories trace back to [the] eighteenth century." ${ }^{30}$ Globalization, as a concept that encompasses intercultural and transnational border crossings, can also be applied to the cultural exchanges that occurred since the 16th century. This term helps us understand how subaltern cultures during this period became empowered through the cultural exchange of ideas. Nonetheless the conventional manner in which scholars discuss colonial globalization often neglects nonWestern cultures from their historical perspective. As Nussbaum argues "Subaltern or peasant peoples have often simply been written out of history and assumed to lack the political and intellectual maturity consonant with European notions of modernity." ${ }^{31}$ Although oftentimes the discourse of globalization entails the study of uni-directional exchanges from Western to non-Western

${ }^{30}$ Felicity A. Nussbaum, The Global Eighteenth Century (Baltimore: The Johns Hopkins University Press, 2003), 6.

${ }^{31}$ Nussbaum, The Global Eighteenth Century , 8. 
cultures, conversations of the opposite cross-cultural influence could benefit the discourse by providing a wider perspective of colonialism. In Europe, ideas of Enlightenment and modernity developed during these centuries and so did their initiative to spread concepts of civilization, progress and technology to the colonies. $^{32}$ Rather than focusing on the particularity of how European concepts affected subaltern cultures, this project centers on globalization as an intercultural concept that allows for cross-cultural and transnational influences in art.

Mexican Baroque art enters discussions of globalization as a hybrid product that contains a fusion of aesthetic qualities revealing intercultural change. Conversations of globalization observe progress in the "New World" as dialectic of adaptation and transformation where Westerners understand the hybridity that occurs in America as linked to a Eurocentric model of maximization. ${ }^{33}$ Going forward however, this project will focus mainly on how the fusion of cultures resulted in a different artistic product that affected the visual culture of the Westerner that brought globalization to America in the first place. In other words, Mexican Hybrid Baroque art, especially sculptural decoration in

\footnotetext{
32 Ibid., 4.

${ }^{33}$ Nikos Papastergiadis, "Tracing Hybridity in Theory," Debating Cultural Hybridity: Multi-Cultural Identities and the Politics of Anti-Racism, ed. by Tariq Modood, et al. (London; New Jersey: Zed Books, 1997), 262.
} 
ecclesiastical architecture, will demonstrate in the following chapters that Spanish artists and art connoisseurs assimilated the result of a cultural hybrid into their own culture. As will be further argued in chapter two, hybridity in Mexican art (Tequitqui) is representative of Mexican identity. Therefore the colonial encounters between the Mexican and Spanish cultures during the colonial period created new artists, new identities and new styles that flourished in an era of globalization.

The Spanish representation of Christian idioms is widely explored in some of Pedro Rojas' research, an art historian and professor at UNAM. It is evident from the content of his work that he speaks about the Spanish artistic tradition in Mexican soil. ${ }^{34}$ Since the arrival of the Franciscans and Dominicans in Latin America in the 16th century, Indigenous artists were trained to represent Christian images. The source of all these representations and forms came from imported European prints, manuscripts and religious books. ${ }^{35}$ The friars learned the different ethnic languages and traditions of the Indigenous populations to

${ }^{34}$ Pedro Rojas describes at great lengths Spanish religious forms and ornamentation during the 18th century in his article titled: Formas Distinctivas de la Ornamentación Barroca Mexicana del Siglo XVIII. This article was published in the "Anales del Instituto de Investigaciones Estéticas de la Universidad Nacional Autónoma de México" in 1967.

35 Jorge Alberto Manrique, "La Estampa Como Fuente de Arte en la Nueva España," Anales del Instituto de Investigaciones Estéticas de la Universidad Nacional Autónoma de México 13-1, no. 50 (1982): 59. 
facilitate communication and thus religious conversion. They encouraged Indigenous people to read and copy these images to ensure the understanding of Christian values and biblical stories. ${ }^{36}$

The Indigenous population saw these images and understood the stories, but not in the way that the friars expected. The images and stories that represented elements of (blessed) water, blood (of Christ) and flowers would be very familiar to the Indigenous people. They were therefore able to make connections with their past traditions and beliefs. The depiction of Christian elements in Mexico was not entirely based on a Western belief system. Indigenous artists produced a hybrid portrayal of these Christian images. Their Indigenous carving, building and drawing skills were implemented into architecture and the blending of these new biblical stories with their traditions resulted in an art that is typically referred to as Tequitqui.

In 1982, Constantino Reyes-Valerio, a prominent Mexican scholar of preHispanic cultures, recognized this. In "El Arte Indocristiano o Tequitqui," he proposes that the illustration and description of the blood of Christ was not foreign to the Indigenous artist. Blood, or as they called it chalchihuite, was

${ }^{36}$ Constantino Reyes-Valerio, "El Arte Indocristiano o Tequitqui," in Historia del Arte Mexicano, ed. Jorge Alberto Manrique (Querétaro, Méx: Salvat Mexicana de Ediciones, 1982), 708. 
prevalent in pre-Hispanic art since it was the food that nourished the Gods [Figure 2.13]. The top portion of this photograph displays a pre-Hispanic stone slab where two warriors are engaging in sacrifice and their blood spilling into a repository. When the friars taught the Indigenous artists that Christ's blood was spilled to save mankind, they associated this idea with the chalchihuite. Similarly with the concept of water [Figure 2.14], the Aztec artist would relate chalchiúhatl (the liquid that fed the Sun) to the concept of blessed water. ${ }^{37}$ This stone sculpture represents an Aztec deity that symbolizes water and fire. The blue paint that covers this effigy represents Tláloc [Figure 2.16], the god of rain and fertility by displaying the precious blue liquid that is water.

Another important component that becomes a hybrid representation is the use of flowers [Figure 2.15]. In pre-Hispanic times, flowers implied the abundance of nourishment, rain and human creation. Indigenous people identified with flowers because they decorated most landscapes and they served as offerings for Tláloc. The depiction of flowers was nothing new to Indigenous artists; they were already accustomed to representing them as decoration on sculptures and architecture [Figure 2.15]. Therefore the representations of flowers, water and blood in Mexican architecture and sculpture were not rooted on the Christian image and meaning, but the artist linked both the new concept

37 Reyes-Valerio, "El Arte Indocristiano o Tequitqui", 722. 
and the existing ideas of a certain element and the result was something hybrid. I believe it is necessary to consider an alternative set of words to describe nonWestern aesthetics created through hybridity because words like Plateresque and Churrigueresque only describe Western decorative styles.

A term that could be implemented in the discussion and study of Mexican Baroque Art History is Mestizo. Although this term has been used to describe racial hybridity in Mexico in the past, it triggered a major debate in the 1920s among scholars because it was broadly and improperly used to describe art. Gauvin Alexander Bailey devotes an entire chapter to this debate in The Andean Hybrid Baroque: Convergent Cultures in the Churches of Colonial Peru. The next few paragraphs will outline some of the main aspects of the controversy caused by the term Mestizo.

The Great Debate, as scholars refer to it, centers on the unresolved historiography of the use of the term Mestizo to describe a style created by people categorized by the same name. The Mestizo population was identified by Spanish 'naturals' as a blend of two cultures resulting in a hybrid identity - fifty percent Spanish and fifty percent American - thus the style is branded with the same 
term. ${ }^{38}$ Although Indian and Mestizo were often used interchangeably since the conquest, the first time Mestizo was used to describe art was by Alfred Neumeyer in $1948 .{ }^{39} \mathrm{He}$ used this term to refer to hybrid art of Latin America in general:

\begin{abstract}
Ordinary terms of evaluation will have to be shelved because the understanding of colonial art has suffered from an undue comparison with the monuments of the Spanish motherland, a method which has blocked an insight into the "folk art" characteristics of Spanish American art. In calling it "folk art," it will also be necessary to examine the design styles of the "folk," i.e. of the Indians who executed architectural and sculptural monuments, an analysis which the work of archeologists will have to supplement. As we recognize the idiomatic use of European motifs, a specific mestizo art will appear, which, by the varying degree of its Indian admixture, can bring forth similar stylistic features in places as far apart from each other as Puebla in Mexico Arequipa in southern Peru. However, observation seems to point to the fact that a true Mestizo style appears only where Indians had attained a high aesthetic culture of their own at the time of the Spanish conquest. ${ }^{40}$
\end{abstract}

Evidently Neumeyer recognizes the complications of labeling non-Western art with what he calls "ordinary terms," which in other words can be understood as

${ }^{38}$ During the colonial era, Spanish painters created 'Casta Paintings' to visually and systematically categorize the different blends of cultures. They did not represent particular people, but rather they depicted a type of person that could fall under a particular racial category.

${ }^{39}$ George Kubler, "Indianism, Mestizaje, and Indigenismo as Classical, Medieval, and Modern Traditions in Latin America," in Studies in Ancient American and European Art: The Collected Essays of George Kubler, ed. Thomas F. Reese (Massachussetts: Yale University Press, 1985), 77.

40 Alfred Neumeyer, "The Indian Contribution to Architectural Decoration in Spanish Colonial America," The Art Bulletin 30, no. 2 (1948): 106. 
Western words. In this paragraph, Neumeyer believes that Mestizo can be used to describe art from many places that share common stylistic features. Neumeyer also states that it is only after the encounter of cultures that the Mestizo style flourishes exponentially.

There are several problems that occur when explaining an artistic style with Mestizo. Localizing a style within an ethnic label seems to be the cause of this debate. ${ }^{41}$ There are two views that resulted from this debate: the "Indigenists" and "Hispanists". Emilio Harth-Terré is a scholar who follows the Indigenist view of the Mestizo Style. He argues that this term is not sufficiently understood by English speakers, so their unfamiliarity with the term justifies its use as an adjective to describe a style. Their understanding of the Mestizo Style encompasses, not the mixture, but the product created by the mixture of cultures. Bailey mentions that Harth-Terré defends the use of this term to describe a style that is reflective of the identity of its artist. ${ }^{42}$ This is akin to the arguments that both Bailey and I adhere to. In Mexico, Mestizo Style or Mestizo is not a word that carries negative or racist implications. Instead, when this term is used as an adjective, Mexicans, in general, register the product of mixing two different

${ }^{41}$ Gauvin Alexander Bailey, The Andean Hybrid Baroque: Convergent Cultures in the Churches of Colonial Peru (Indiana: University of Notre Dame Press, 2010), 1718. 42 Ibid., 29. 
cultures. Therefore, the use of this term could be suitable to describe the style shaped by those with hybrid identities into a new style. On the other side of the debate are George Kubler and Graziano Gasparini, who, according to Bailey, are Hispanists. They argue that Mestizo is a racist and derogatory term. Kubler states "the term is abusive to nearly everyone in the Andean region, to the mestizo people, whom it singles out, as well as to the creoles, Spaniards, Indians and Negroes, whose many contributions it excludes." ${ }^{43}$ In another instance Kubler said "the term mestizo is a racialist expression and an inadequate designation for works of visual art."44 It is evident that for some scholars the use of ethnic terms used as labels to describe art is a worrisome academic problem. Gasparini dismisses the use of Mestizo Style in architecture due to its tendency to highlight decorative modalities instead of focusing on architectural values. ${ }^{45}$ In 1964, a petition was passed to twelve art historians and architects to vote for or against the use of the term Mestizo Style in literature. Notably most of the Hispanist participants were not of Latin American descent. Two of them (Robina and Kubler) disputed its use while the rest approved it. ${ }^{46}$ This "intellectual fencing" 47 encouraged academics to suggest alternative terminology to refer to a hybrid

43 Bailey, The Andean Hybrid Baroque, 28.

44 Kubler, "Indianism, Mestizaje, and Indigenismo as Classical, Medieval, and Modern Traditions in Latin America", 75.

45 Bailey, The Andean Hybrid Baroque, 30.

46 Kubler, "Indianism, Mestizaje, and Indigenismo as Classical, Medieval, and Modern Traditions in Latin America," 77.

47 Bailey, The Andean Hybrid Baroque, 19. 
style in Latin America, among which criollo, Créolerie, hispano-indigenous, iberoindigenous, ${ }^{48}$ and other hyphenated terms were proposed. There is value in this dispute for art historians to realize the importance of language in framing art.

The term "Andean Hybrid Baroque" has been proposed by Bailey to speak about the blending of cultures resulting in a stylistic phenomenon without referring to racial categorizations. In his book, Bailey examines the hybrid Baroque art of South America (i.e. Peru to Chile), arguing that this term "is more useful for an art historical study because it relates more specifically to how this culture fits into an international stylistic movement." 49 Similarly in the literature of Mexican Hybrid architecture there is a term that describes the fusion of Christianity with Indigenous cultures. In 1942, Spanish art historian José Moreno Villa bestowed this style with the term Tequitqui to refer specifically to the outcome of the blending of cultures created during the 16th century..$^{50}$ What Alexander Bailey calls Estilo Mestizo in his introduction ${ }^{51}$ is similar to what Moreno Villa describes as Tequitqui in his writings of Mexican Hybrid Art. Many

\footnotetext{
48 Ibid., 77.

49 Ibid., 2.

${ }^{50}$ Reyes-Valerio, "El Arte Indocristiano o Tequitqui," 710.

51 "...Estilo Mestizo (Mestizo Style), this flourishing school of carving is distinguished by its flattened, textile like decoration - achieved by cutting into the stone rather than sculpting in the round - and its virtuoso combination of European late Renaissance and baroque forms with Andean sacred and profane symbolism, some of it deriving from the Inca and pre-Inca past". (p.1)
} 
scholars post-Moreno Villa use this Nahua ${ }^{52}$ term to refer to this hybrid style. The term means "tributary", similarly to Mudéjar, the term used to describe the Spanish-Moorish style in Spain. John McAndrew believes that Tequitqui style is not completely Spanish nor Indigenous, but the result of a perfect embrace of both styles that creates what he calls "Mexican Art". ${ }^{33}$ Aguilar Moreno believes that Tequitqui art is an example of "the indigenous persistence [which] was exactly what gave a touch of joy and emotion to the serenity of Spanish Art, transforming it in a new and different native paradigmatic style that does not exist in Europe."54 Martha Fernández, who wrote her PhD Dissertation on this subject, concludes that "... tequitqui art is an original interpretation of European models copied by indigenous peoples who left their native sensibility as a footprint in art." 55 Nonetheless Fernández claims that this 'mode of art', as she calls it, only manifests in the 16th century. Although we are certain that Tequitqui style began in the 16th century, I propose, as Moreno Villa does, that Tequitqui art continued into the 17th and 18th centuries. Referring to 18th-century Mexican art, Constantino-Valerio says that "[a]lthough indigenous traditions could not be forgotten they lost strength as they mixed with Christian traditions to form a religious hybridity that is still practiced today by the Mexican population at

${ }^{52}$ Nahua is the ancient language spoken by the Indigenous population in Mexico. 53 Reyes-Valerio, "El Arte Indocristiano o Tequitqui," 710.

${ }^{54}$ Aguilar Moreno, "Tequitqui Art of 16th-Century Mexico,"114.

55 Reyes-Valerio, "El Arte Indocristiano o Tequitqui," 711. (My own translation, see appendix 1 for original text) 
large."56 Based on these considerations, as an explanatory term, Tequitqui can be used to describe the architectural decorative style that developed from the 16th century into the 17th and 18th centuries. The continuation of the use of this term provides accurate meaning to Mexican Baroque tradition in architecture and sculpture because "it is an indigenous word that describes the nature of their own artwork." 57 Some examples of Tequitqui style in architectural sculpture during the 17th and 18th centuries are in the church of Santa María Tonantzintla in Puebla [Figures 2.10-2.12], the Chapel of El Rosario also in Puebla [Figure 2.17], and the Santuario de Ocotlán in Tlaxcala [Figure 2.18], which will be discussed in the following chapters of this thesis.

${ }^{56}$ Constantino Reyes-Valerio, Arte Indocristiano: Escultura del Siglo XVI en México (Mexico City: INAH, 1978), 140. (My own translation, see appendix 1 for original text)

${ }^{57}$ Aguilar Moreno, "Tequitqui Art of 16th-Century Mexico," 108. 


\section{Chapter Two}

\section{Mexican Baroque: Artist Training and Expression of Identity}

To expand on the differences between Spanish and Mexican Baroque styles of architecture and sculpture, a few examples within Mexico will be examined. As mentioned in the first chapter, Mexico City has many examples of Spanish Baroque style on Mexican soil. Therefore it is necessary to discuss examples from this city to demonstrate that the style we recognize is not innately Mexican, but Spanish. Alternatively, outside Mexico City several architectural examples will prove that the style transforms when the artist is not Spanish and when his innate need to express his own identity results in a different representation of Christian idioms. Two elements influence this change in style. First it is important to recognize that Mestizo and Indigenous artist training was unlike the training given to Spanish architects during the colonial era. Secondly, one must consider that the identity of Mestizo and Indigenous artists stimulated the creation of Tequitqui or hybrid architectural style.

Spanish architect Jerónimo de Balbás (1680-1748) brought the Churrigueresque style to Mexico, which is most visible in the downtown core of Mexico City at the Metropolitan Cathedral. The Retablo de los Reyes [Figure 3.1] 
and Retablo del Perdón [Figure 3.2] carry estípites ${ }^{58}$ and high levels of ornamentation as is common for Churrigueresque churches and retablos in Spain. These vertically inclined architectural elements are covered in gold and their ornamentation consists of Christian symbols, golden vegetation, and wooden sculptures in the estofado ${ }^{59}$ technique as well as cherub faces.

No further than 250 kilometers from Mexico City is the city of Querétaro. The convent churches of Santa Clara, Santa Rosa and the courtyard of the convent of San Agustín look similar to this Spanish style brought to Mexico City by Balbás. However at a closer look, Mestizo and Indigenous artists such as Ignacio Mariano de las Casas, Francisco Martínez Gudiño, Pedro José Rojas and Maestro Ximénez designed the decoration of these retablos and they demonstrate that they were able to create their own version of this style. In Santa Clara and Santa Rosa, there is an evident obsession with filling every available space with patterns and ornaments [Figure 3.3]. Some of the cherubs and other figures in these Queretan convent churches present a physiognomy akin to the Indigenous populations [Figure 3.4]. Pertinent features of these churches are the presence of color, a variety of native flowers and an overwhelming abundance of vegetation [Figures

${ }^{58}$ Estípite is an inverted pilaster that is sometimes used for support but mostly for decorative purposes.

${ }^{59}$ Estofado sculptures are made of wood and covered in elaborate gilding and polychroming to imitate textiles. This technique revived in the 18th century through Churriguera's retablos. 
3.5-3.7]. Although these convent churches are representative of the inventive nature of the Mestizo and Indigenous artist, it is necessary to clarify that there are copious amounts of examples in the state of Querétaro that fit into this hybird style, including the missionary churches in the Queretan Sierra Gorda.

The city of Puebla and the town of San Andrés of Cholula, both in the state of Puebla, and Ocotlán in Tlaxcala are also within a 200 kilometer radius of Mexico City. In La Capilla del Rosario, Santa María Tonantzintla and El Santuario de Ocotlán we encounter different iconography, representation of Indigenous physiognomy [Figure 3.8], extensive use of color [Figure 2.11] and a representation of native flora, fauna and fruit [Figures 3.10-3.12]. Pueblan artists were adept at working in any type of material, thus they achieved a very unique style of decoration (different from the style found in Mexico City). ${ }^{60}$ The symbolic value of these features found in these Pueblan and Tlaxcalan examples point to the shift in sculptural stylistic design and to a new expressive aesthetic language. There is a tendency to fill every space with patterns and ornaments. The presence of estípites remains but they are used as niches and are decorated differently. The cherub faces change; they reflect more of an Indigenous physiognomy. These

60 Jesús Pérez Morera, "Formas y Expresiones de la Platería Barroca Poblana: Repertorio Decorativo, Técnicas y Topologías," Anales del Instituto de Investigaciones Estéticas de la Universidad Nacional Autónoma de México 34, no. 100 (2012): 128. 
elements are unmistakably Tequitqui and must be distinguished from the Churrigueresque style. There are copious examples of Tequitqui art in other nearby states like Zacatecas, Aguascalientes and Guanajuanto among other states that must be explored further.

One of the main aspects that define the differentiation of style is artist training. Indigenous and Mestizo training differed greatly from Spanish architects that lived in Spain or in Mexico City. First it is critical to understand what it meant to be an architect during Spanish colonial rule in New Spain. In Spain, the trades of bricklayer (albañil), architect and master builder (alarife) were all meant to be positions given to different individuals. A person would study to occupy one of three trades: an albañil, architect or alarife. However, in New Spain the differences were less defined among the three positions. One could be all three or one could be considered an albañil if he had basic knowledge of architecture. ${ }^{61}$ In other words, holding the title of architect could mean holding one or all three positions in the early centuries of colonial era in New Spain. ${ }^{62}$ Only after 1746 were 'Ordenanzas' proposed to officially change the construction trade into an art. According to these new laws, those known previously as 'maestros de

61 Martha Fernández, "El Albañil, El Arquitecto y el Alarife en la Nueva España," Anales del Instituto de Investigaciones Estéticas de la Universidad Nacional Autónoma de México 14, no. 55 (1986): 55-56.

62 Ibid., 56. 
albañilería' were now titled 'architects'. ${ }^{63}$ However, Toussaint explains that "[o]rdinances were framed to protect the members of the guild. No one could be a master of architecture but a Spaniard of recognized standing and good character, with all qualifications supported by testimonials. This is to say, Indians and Mestizos were excluded from the profession." 64 If this was so, then how did the Indigenous and Mestizo prepare themselves as architects?

Those who were not accepted into academies had to learn their trade by attending artist studio lessons. Francisco Martínez Gudiño, for instance, obtained his architecture and retablo construction skills by attending classes at his father's studio. Eventually Martínez Gudiño opened his own retablo studio in Querétaro where other Mestizo and Indigenous artists could work and learn the trade. ${ }^{65}$ The Xuárez was an Indigenous family who owned a famous artist studio in Mexico City. They received many commissions all around Mexico from important art patrons such as Don Diego de Malpartida Zenteno and Don Juan de Caballero y Ocio.66 These characters were close to the Archbishop of Mexico and held

${ }^{63}$ Fernández, "El Albañil, El Arquitecto y el Alarife en la Nueva España," 57. 64 Toussaint, Colonial Art in Mexico, 278. ${ }^{65}$ José Rodolfo Anaya Larios, Francisco Martínez Gudiño: Un Maestro del Barroco Querétaro (Querétaro: Universidad Autónoma de Querétaro, 2003), 25. ${ }^{66}$ Gustavo Curiel, "Nuevas Noticias Sobre un Taller de la Nobleza Indígena," Anales del Instituto de Investigaciones Estéticas de la Universidad Nacional Autónoma de México 15, no. 59 (1998): 134. 
important political and religious roles in the colony. Caballero y Ocio, for instance, held Inquisition tribunals. ${ }^{67}$ The Xuárez family was dedicated to building retablos. Although very few of the retablos created by this family survive, it is important to note that the recognition for the retablo was typically given to the person who designed the decoration of it, not to those who completed it. ${ }^{68}$ In some cases the patron who commissioned art for a church was considered more important than the artist who produced it. After trying to find the names of the artists who created Tequitqui art in history and Art history books, it became evident that Indigenous and Mestizo artists are largely excluded from this literature, especially books that address Mexican Art history. It is essential to review the names and undertakings of these architects who left Mexicans with an extensive artistic heritage. More importantly Tequitqui art is an embodiment of Mexican identity. Mexicans are heirs to the composite of Indigenous and colonial pasts that make their identities and artistic products fundamentally cosmopolitan. ${ }^{69} \mathrm{We}$ must bestow historical value upon those artists whose legacy continues to stand in the Mexican landscape.

\footnotetext{
67 Curiel, "Nuevas Noticias Sobre un Taller de la Nobleza Indígena," 141. ${ }^{68}$ Ibid., 132.

${ }^{69}$ María Fernández, Cosmopolitanism in Mexican Visual Culture (Austin: University of Texas Press, 2014), 28.
} 
The artist's identity is an influential factor that we encounter in the creation of art. As previously mentioned, theoretically the work of art cannot be separated from the artist and his/her own identity. An artist and his/her art object exist unified forming an integral invisible connection that is constantly challenged by philosophy, religion, society, politics, economy and culture of the time..$^{70}$ Regarding Mexican Baroque art Vargaslugo believes that "[it] possesses its own American personality and should be seen as one of Mexico's most important contributions to art history. It is as rich and wide-ranging as the population that created it."71 The different symbols and use of color used by Indigenous and Mestizo architects and sculptors were not part of Spanish design but rather results of their own creativity and environment. Even if Spanish architects created the design, it seems unlikely that they dictated the hybrid result. Martha Fernández says "Mexican architecture is the result of local creativity; we can easily distinguish the creation of a Mexican Baroque façade or retablo from a Spanish or European product."72 Ultimately Mexican Baroque architecture exudes a different expression of identity. Because Mestizo and Indigenous artists were necessarily different in birthrights to the Spanish, they faced the challenge of creating their own identity that connected them to their ancestry and to their new

70 Reyes-Valerio, Arte Indocristiano, 107.

${ }^{71}$ Elisa Vargaslugo, México Barroco, 14. (My own translation, see appendix 1 for original text).

72 Martha Fernández, Estudios Sobre el Simbolimo en la Arquitectura Novohispana (Mexico City: UNAM, 2011), 20. 
land and religion. ${ }^{73}$ This resulted in a hybrid style that consisted of altered interpretations of Christianity and its symbols.

Spanish connoisseurs from this period, including Diego Durán, Francisco López de Gómara and Juan de Palafox y Mendoza, noted that this hybrid style was special. Their testimonies attest to the creativity of the Indigenous and Mestizo artists since the 16th century. The Spanish public was visually drawn to the hybrid style because of two main reasons: its different aesthetic and uniqueness. The visual surroundings of the Spanish architect and connoisseur were no longer European. When the Spanish stepped foot in Mexican land, their geography of art changed. It is at this point in time that they became isolated for prolonged periods of time from contemporary changes in European art. Instead the Spanish were faced with Indigenous and Mestizo art.

Since the conquest in the 16th century Mexico has been a contact zone. Mary Louise Pratt defines a contact zone as a space where contrasting cultures meet, collide and struggle with each other. ${ }^{74}$ In this case the Spanish demonstrated an interest in the culture of this new territory. Testimonies from important historians like Dominican friar Diego Durán and Francisco López de

73 María Fernández, Cosmopolitanism in Mexican Visual Culture, 32.

${ }^{74}$ Mary Louise Pratt, Imperial Eyes: Travel Writing and Transculturation, 2nd ed (London; New York: Routledge, 2008), 7. 
Gómara provide evidence that Europeans were interested in the uniqueness of the pre-Hispanic culture. In these documents they describe many architectural features of buildings. It is common to find a negative interpretation of Indigenous art symbols because most of their writing was mediated by their own Christian system of beliefs. Once they disregard the intervention of their religious faith, Spanish writers opened up to understanding what pre-Hispanic art was, allowing themselves to appreciate it. ${ }^{75}$ For example Friar Diego Durán at first described a sculpture "made of carved stone [showing] an effigy of a frightening monster with an ugly face that bared the likeness of a snake with large fangs, it was lit and coloured by fire that symbolized the lightning sent from the heavens"76 [Figure 3.13]. Through his use of language it is clear that his tone is disapproving and that he saw this new world through his Christian lens to analyze this pre-Hispanic sculpture. After he steps outside of these Christian parameters, he says of a Huichilobo temple: "This temple housed a tall and beautifully built idol (...) the room had large quantities of blankets adorned with colorful feathers which is one way the people of this nation decorate"77 [Figure 3.14]. In this last testimony Durán admires pre-Hispanic taste because it is different from his European

75 Ida Rodríguez Prampolini, "El Arte Indígena y los Cronistas de la Nueva España," Anales del Instituto de Investigaciones Estéticas de la Universidad Nacional Autónoma de México 5, no. 17 (1949): 10-11.

${ }^{76}$ Fray Diego Durán, Historia de las Indias de Nueva España y Islas de Tierra Firme, Vol. 1 (México: Impresoras Ignacio Escalante, 1880), 135. (My own translation, see appendix 1 for original text).

${ }^{77}$ Ibid., 22. (My own translation, see appendix 1 for original text). 
predilections and it is an unfamiliar artistic expression. Durán's accounts are only two examples of the innumerable Spanish chronicles of the fascination for Indigenous artistic expression in the early decades of colonialism.

Testimonies are available throughout Spanish colonial rule in Mexico. They provide evidence that enables Mexican Art history scholars to pursue the study of cross-cultural consequences of colonialism. Another avenue that could lead researchers to the on-going investigation of hybrid styles affecting the visual culture of the conqueror is through the pragmatic use of images on printed material. The creation of prints and drawings during colonialism was widely practiced in New Spain. Therefore an effort must be made to locate evidence that Spanish travelers, architects, friars or art lovers transported these portable and affordable visual tools back to Europe for the dissemination of this hybrid visual culture. The practical nature of this medium makes it a great agent of cultural cross-pollination. Scholars like Kelly Donahue-Wallace who ventured in this direction already discovered that most prints and drawings from this period existed, but it is still unknown whether they survived. Those that survived illustrate religious themes, coats of arms, maps or funerary prints among other 
types of non-architectural elements. ${ }^{78}$ It is indisputable that prints and drawings were instrumental in the dissemination of religion in Latin America during Spanish colonial rule. They were also used by architects as models for the production of contemporary European styles in the colonies. ${ }^{79}$ Ultimately it is plausible for prints and drawings of Tequitqui style to be found in Spain and for them to have influenced the visual culture of the conqueror. Due to the lack of search results at Mexican archives ${ }^{80}$ I was unable to find any relevant prints or drawings. Although written testimonies exist and are available at the National Archives of Mexico (AGN), I remain hopeful that at least some prints are hidden somewhere in the AGN or in the Archive of the Indies in Seville, Spain. For the purposes of this investigation, written statements function as evidence to prove that Indigenous and Mestizo artists, while trying to express their new identity through art, created a hybrid style that visually impacted the Spanish audience.

A contact zone, as discussed above, is not only a space of colonial encounters, but it is also a space where transculturation occurs. Fernando Ortiz, a Cuban sociologist, coined this term in the 1940s to replace acculturation and

${ }^{78}$ Manuel Romero de Terreros, Grabados y Grabadores en la Nueva España (México D.F.: Talleres Gráficos de la Compañía Editora y Librera ARS, S.A., 1948), 10.

${ }^{79}$ Kelly Donahue-Wallace, "Picturing Prints in Early Modern New Spain," The Americas 64, no.3 (Jan 2008):330, http://www.jstor.org/stable/30139132. 80 I searched in the National Archives of Mexico, National Library of Mexico, among other official libraries in Mexico. 
deculturation, two terms that were paired to describe the transferring of culture "in a reductive fashion imagined from within the interests of the metropolis." 81 However in this case transculturation is used to refer to how this encounter resulted in an exchange, and absorption of each other's culture. Therefore in this colonial encounter I propose that the transculturation is mutual. Although it is undeniable that the relations of power were asymmetrical during this period, it is evident through written testimonies that the subordinate contributes to the conqueror's visual culture. In the following chapter written testimonies will explain how Europeans viewed the work of Indigenous and Mestizo artists and Tequitqui art as a style that carried an emphasis on expressions of new identities.

81 Pratt, Imperial Eyes, 245. 


\section{Chapter Three}

The Visual Affects of Mexican Hybrid Baroque Architecture and Sculpture

In the 16th and 17th centuries Spanish chronicles continue to indicate that Indigenous and Mestizo visual culture was distinct from what European eyes had witnessed before. Although artists of this new land were using sculptural idioms of the conqueror, they illustrated them in an atypical manner. Among the many testimonies found in the literature of these centuries, two were chosen for the purposes of this project. The first one covers the state of Puebla and the Indigenous and Mestizo population at large and the second one speaks of a specific church and Indigenous artist in Ocotlán, Tlaxcala.

Puebla de los Ángeles was founded in 1531 as a site of Spanish administration..$^{82}$ Located only two hundred and fifty kilometers away from the main metropolis - Mexico City - Puebla saw a rapid growth of industries that brought economic prosperity to the colony. As early as 1566, Puebla became the first city in the Americas to produce large amounts of wool. Also important was the production of textiles, glass and ceramics. The fabrication of ceramics is especially relevant because potters from Talavera de la Reina (Spain) brought it

82 Elisa Vargaslugo, "Juan de Palafox y Mendoza y el Arte Barroco en Puebla," in Palafox: Iglesia, Cultura y Estado en el Siglo XVII, Congreso Internacional, IV Centenario del Nacimiento de Don Juan Palafox y Mendoza, ed. by Congreso Internacional Palafox (Pamplona, Spain: Universidad de Navarra, 2001), 353. 
to Puebla where it continues to flourish today as it did in the 16 th century. Nowadays the production of ceramics is considered a staple of Pueblan visual culture [Figure 4.1]. In the mid 1600s, the first printing press arrived in Puebla, placing it as a major cultural center in Mexico. In 1642 this prosperous city saw the arrival of Juan de Palafox y Mendoza, who came to occupy the prestigious position of Bishop. ${ }^{83}$ Although Palafox y Mendoza lived a highly political and religious life, his role in the arts became one of the most studied aspects of his life. Montserrat Galí Boadella, a scholar from the Institute of Social Sciences and Humanities at BUAP, ${ }^{84}$ says that Palafox y Mendoza understood the function of art as a portrayal and confirmation of political power. He was also aware that art performs a symbolic function in society. 85 Throughout his life Palafox y Mendoza was involved in the art world as a print, sculpture and painting collector and was an avid reader of art theory.

Palafox y Mendoza was an invaluable character in the production of colonial art in Puebla. Not long after his arrival in New Spain, he supervised the erection of the Cathedral of Puebla in the downtown core, one that visitors can

83 Vargaslugo, "Juan de Palafox y Mendoza y el Arte Barroco en Puebla," 354. 84 BUAP stands for Benemérita Universidad Autónoma de Puebla.

85 Montserrat Galí Boadella, "Juan de Palafox y el Arte: Pintores, Arquitectos y Otros Artífices al Servicio de Juan de Palafox," in Palafox: Iglesia, Cultura y Estado en el Siglo XVII, Congreso Internacional, IV Centenario del Nacimiento de Don Juan Palafox y Mendoza, ed. by Congreso Internacional Palafox (Pamplona, Spain: Universidad de Navarra, 2001), 367. 
still appreciate today. By supervising the building process of this cathedral and many other art commissions, Palafox y Mendoza assumed responsibility for the artist and architects involved so that they would receive proper recognition for their professional work. He was always concerned with promoting those he considered the best contemporary artists in the region for artistic commissions. ${ }^{86}$ Also while he was a Bishop in Puebla Palafox y Mendoza personally assessed and revised the plans and iconography proposed by the artists. ${ }^{87}$ In the case of the Cathedral of Puebla, Mestizo architect Agustín Hernández de Solís, ${ }^{88}$ who was the iconographer of Capilla del Rosario, was also responsible for the architectural program of the Pueblan Cathedral. As one of the reputable architects in the area, Hernández de Solís received a promotion by Palafox y Mendoza in 1645.89 Evidently Palafox y Mendoza was thoroughly invested in the artistic community and saw that it flourished under his religious and political rule.

After his position as a Bishop, Palafox y Mendoza was appointed as Viceroy of Mexico in 1640 until he engaged in a dispute with the Jesuits, who after winning the case succeeded in sending him back to Spain. While Palafox y

\footnotetext{
86 Galí Boadella, "Juan de Palafox y el Arte," 377.

87 Ibid., 377.

${ }^{88}$ Agustín Hernández de Solís is one of the only Mestizo artist names to appear in Palafox y Mendoza's writings. Although I was unable to find further information on him, the mention of his name marks a starting point to expand Mexican Baroque Art and Artist History. 89 Galí Boadella, "Juan de Palafox y el Arte," 371.
} 
Mendoza held the privileged post of Viceroy, he sought to reform ecclesiastical bureaucracy. The polemical debate began when the Jesuits, who owned a large portion of land in New Spain, refused to pay ecclesiastical taxes to the state administered by Palafox y Mendoza. This, among other reasons, prompted a dispute during which the Jesuits resisted and Palafox y Mendoza demanded payment and compliance..$^{90}$ In terrible need of support, Palafox y Mendoza turned to some of his colleagues who, to his demise, sided with the Jesuits in this discussion. In this unfortunate series of events, the ecclesiastical judges deemed the Jesuits' case stronger than Palafox y Mendoza's and he was swiftly excommunicated. ${ }^{91}$ Upon his return to Spain, Palafox y Mendoza wrote a treatise dedicated to King Philip IV titled Historia de las Virtudes del Indio now more commonly referred to as Naturaleza y Virtudes del Indio. ${ }^{92}$ Most chapters include important and positive statements about the Indigenous people of Mexico that reveal Palafox y Mendoza's genuine interest and appreciation for their merits, virtues, traditions and culture.

${ }^{90}$ Michael Manuel Brescia, "The Cultural Politics of Episcopal Power: Juan de Palafox y Mendoza and Tridentine Catholicism in Seventeenth-Century Puebla de los Angeles, Mexico" (PhD thesis, University of Arizona, 2002), 12.

91 Ibid., 300-301.

92 Joaquín Salcedo Izu, "Palafox, Defensor de los Indios," in Palafox: Iglesia, Cultura y Estado en el Siglo XVII, Congreso Internacional, IV Centenario del Nacimiento de Don Juan Palafox y Mendoza, ed. by Congreso Internacional Palafox (Pamplona, Spain: Universidad de Navarra, 2001), 273. 
In the prelude to his treatise, Palafox y Mendoza requests King Philip IV's reflection on the laws that abide the Indigenous population. He states "with my knowledge and respect I have for your Majesty I implore that you consider our blessed services as ministers and Bishops as enough reason to permit the creation of more effective laws... being your holy decision to bestow me with these positions I feel obliged to take this pen and offer your Majesty with my suggestions..."93 Palafox y Mendoza's personal experiences and knowledge of the Indigenous population in Mexico motivated him to address the King of Spain with his concerns and defend the rights and innate virtues of these people. In the sixteenth chapter of his treatise, Palafox y Mendoza admires the competence of Indigenous people. He commends their ability to excel at new professions and mentions that, at times, Indigenous techniques surpassed, not only those of the Spanish artists and architects, but of all nations. ${ }^{94}$ Palafox y Mendoza states "The comprehension and tact to understand any trade, as difficult as it may be, is strange and [in this regard] I do not doubt [the Indigenous tradesmen] surpass all nations..."95

\footnotetext{
93 Juan de Palafox y Mendoza, De la Naturaleza y Virtudes del Indio, 2nd Ed (Puebla: Gobierno del Estado de Puebla; Secretaría de Cultura, 1989), 8-9. (My own translation, see appendix 1 for original text). 94 Salcedo Izu, "Palafox, Defensor de los Indios," 278. 95 Palafox y Mendoza, De la Naturaleza y Virtudes del Indio, 41. (My own translation, see appendix 1 for original text).
} 
The sixteenth chapter of Naturaleza y Virtudes del Indio opens with a strong line: "And as for the practical and mechanical arts the Indigenous are exceptionally talented, especially in painting, gilding, carpentry, masonry, other stonework and architecture; they are not only good at these professions, but they master each line of work."96 A connoisseur of art and art theory, Palafox y Mendoza was able to recognize the skillful work of Indigenous artists in Mexico and although he fails to provide King Philip IV with individual examples of art or architecture, he acknowledges the Indigenous artist's overall competence in the arts. In spite of the lack of examples, he indicates that there was a special Indigenous master who worked at the Cathedral of Puebla. This unnamed artist was known as siete oficios - seven professions - because he was eminently talented in all trades. Palafox y Mendoza must have encountered this artist or his colleagues who spoke highly of him since he describes that siete oficios had the capacity to comprehend any instruction and that he could efficiently troubleshoot. Palafox y Mendoza assures us that "In Atlixco, one of the towns of Puebla de los Angeles, saw the arrival of a Spaniard and an Indigenous man who came to learn to sing organ songs with the chapel master in the Atlixcan church; while in over two months the Spaniard was not able to read notes to understand

\footnotetext{
96 Palafox y Mendoza, De la Naturaleza y Virtudes del Indio, 41. (My own translation, see appendix 1 for original text).
} 
the music, the Indigenous man was singing in less than fifteen days." ${ }^{97} \mathrm{He}$ recognizes that it was not simply the copying of Spanish methods that made Indigenous artists masters, but it was their innate proficiency to work with different materials and create beauty with them that provided value to their work, even in music.

A great example of Indigenous creativity and skillful fabrication of art is the Capilla del Rosario [Figure 2.16]. Housed within the premises of the Templo of Santo Domingo, a church that is otherwise covered in Churrigueresque style retablos made by Spanish sculptors and architects; this chapel provides viewers with a juxtaposition of Spanish and Mexican Baroque in one building. This 1690s chapel in Puebla is currently considered the eighth wonder of the world. ${ }^{98}$ Upon entering the chapel one is immediately taken emotionally by the vivid use of stucco and gold. The entire surface of the chapel is covered with decoration. On the sidewalls we can admire paintings surrounded by an interlace of golden gilded stucco that at times exposes human figures [Figures 4.2-4.4]. These figures illustrate an intriguing physiognomy that ceases to depict the likeness of a Spanish or white individual. Close reflection and observation reveals the likeness

97 Palafox y Mendoza, De la Naturaleza y Virtudes del Indio, 41. (my own translation, see appendix 1).

98 Francisco de la Maza, "La Decoración Simbólica de la Capilla del Rosario de Puebla," Anales del Instituto de Investigaciones Estéticas de la Universidad Nacional Autónoma de México 14, no. 55 (1986): 6. 
of pre-Hispanic Indigenous soldiers [Figure 3.8-3.9]. The presence of fruit, animals and other vegetation are also prominent elements of the decoration. When the chapel was inaugurated in 1690, Diego de Gozorpe, the Friar who oversaw its completion declared that the Capilla del Rosario was "a representation of spring that flourished with flowers and with manifestations of mysterious symbols." ${ }^{99}$ It is important to note that the iconographical design of this chapel was conceived by a Mestizo artist whom Palafox y Mendoza commends for his outstanding artistry. Although Hernández de Solís designed the iconography of this chapel, the names of the Indigenous architects and sculptors who assembled his design are not mentioned in Mexican Art history books. The names of the architects and sculptors who raised this chapel have yet to surface, and can be a difficult challenge for scholars to dive into the depths of archival documents to find them. Entering this site provides visitors with an emotional experience caused by this unique hybrid style, and what is interesting is the local pride for this surviving Indigenous creation.

Another example of skilled Indigenous artistic creation in Baroque architecture and sculpture that still stands is situated in Ocotlán, Tlaxcala. This small town is not distant from the state of Puebla. For this reason it is believed

99 De la Maza, "La Decoración Simbólica de la Capilla del Rosario de Puebla,"10. (My own translation, see appendix for original text). 
that a lot of the artistic influence found in Tlaxcala originated from the Baroque cultural center of Puebla. Ocotlán comes from the náhuatl word ocotl, a term that denotes a type of wood known as ocote [Figure 4.5]. The last of the word Ocotlán comes from tlatla, which means to burn in náhuatl. Therefore Ocotlán means "the ocote that burns." ${ }^{100}$ Mexicans know that ocote is particularly flammable and it is still used as a fire starter today. In 1755, the Virgin of Ocotlán [Figure 4.6] was proclaimed the protector of the city of Tlaxcala by Bishop Don Domingo Pantaleón y Álvarez de Abreu. ${ }^{101}$ It is believed that the Virgin of Ocotlán appeared to Juan Diego, an Indigenous man, on his way home. In this vision she guided him to an ocote tree where she miraculously made a spring emerge. The water from this spring was meant to cure Tlaxcaltecs from a pest that infested their land at the time. ${ }^{102}$ Consequently the Santuario de Ocotlán [Figure 2.18] was built on the exact place where Juan Diego ${ }^{103}$ saw the spring emerge. The construction of this building saw the participation of the Tlaxcaltecan community, as they were the ones who carried materials to the site of construction and erected the church. Finished in 1745 , it took over sixty years to complete, although the façade dates

100 Viridiana Vera García, Inventario del Archivo Parroquial de Nuestra Señora de Ocotlán, Tlaxcala (México: Apoyo al Desrrollo de Archivos y Bibliotecas de México, A.C., 2008), 11.

101 Ibid., 13.

102 Marina E. Kalpan, "Ocotlán y la Estética del Barroco," Anales del Instituto de Investigaciones Estéticas de la Universidad Nacional Autónoma de México 14, no. 56 (1986): 53.

103 Note that this Juan Diego is not the same Juan Diego from the Virgen Guadalupe story. 
to $1780 .{ }^{104}$ The Santuario went through a lot of changes throughout history, but the only sections left untouched are the Camarín and the presbytery. However, through the surviving writings of a Spanish priest, scholars are able to determine what the likeness of this church was in the 18th century. Franciscan priest Manuel de Loayzaga was the appointed representative of the Santuario de Ocotlán in 1716 and was the author of Historia de la Milagrosissima Imágen de Nuestra Señora de Occotlán [Figure 4.7]. This text is imperative to the study of this church as it contains very explicit mention of an Indigenous artist and his outstanding sculptural work. Loayzaga oversaw the creation of many elements of the Santuario including the Camarín, the main retablo, Francisco Xavier's retablo, San José's retablo, the gilding of the pulpit, the production of chairs, benches and tables, ${ }^{105}$ all made by Francisco Miguel Tlayoltehuanitzi. ${ }^{106}$

Loayzaga describes Francisco Miguel's creations in explicit detail, but he also devotes a large part of his text to make it clear to the reader that this artist had a talent out of the ordinary. Francisco Miguel chose to work by pure religious devotion and therefore donated his time and talents to the Santuario de

104 Kalpan, "Ocotlán y la Estética del Barroco," 55.

105 Ibid., 56.

106 The Tlaxcalan government's uses this last name on their website: www.tlaxcala.gob.mx. No scholarly sources confirm this, but it is said by locals that the archives of the city of Tlaxcala - which are indefinitely out of commission for public consultation - contain documentation of this last name being accurate. Otherwise the artist is called by his first and middle name, Francisco Miguel. 
Ocotlán. ${ }^{107}$ Loayzaga writes the life story of this particular architect whose work he respected. The story says that one day Francisco Miguel slipped and fell down trapping his foot between two rocks unable to recover. According to the author's account, the Virgin of Ocotlán saved his life. She suspended his body in the air and lifted him out of this misery. Deeply grateful for her assistance Francisco Miguel decided to leave his life behind to devote his time as a religious recluse of the Santuario de Ocotlán where he spent twenty-five years of his life. ${ }^{108}$ Loayzaga recites Francisco Miguel's story with sincere admiration. He says that Francisco Miguel was a humble and devout Christian whose body lies in the Santuario where he worked insatiably. Francisco Miguel passed in 1749.109

Francisco Miguel's first oeuvre for this church was the Camarín ${ }^{110}$ [Figure 4.8], which he completed in 1733.111 Located off main sight, the Camarín stands out as the stylistic deviant from the rest of the church since the rest of the building carries a Spanish Churrigueresque style. Loayzaga believed that anyone who would encounter this place would experience an inevitable ecstasy triggered by astonishment. He also believed that this Camarín did not compare to any

\footnotetext{
107 Kalpan, "Ocotlán y la Estética del Barroco," 56.

${ }^{108}$ Angel T. Santamaría, Nuestra Señora de Ocotlán, Tlaxcala, 3rd ed (Mexico D.F.: Grupo Infagon S.A. de C.V., 2002), 24.

${ }^{109}$ Santamaría, Nuestra Señora de Ocotlán, Tlaxcala, 24.

${ }^{110}$ Camarín is a room inside a church where the dresses and jewelry of the Virgin in question are held.

111 Kalpan, "Ocotlán y la Estética del Barroco," 56.
} 
European creations he had encountered in the past.112 The Camarín is filled to capacity with stucco decoration. By and large this decoration consists of vegetation and flowers. A glorious heaven of flowers is how Loayzaga understood this space. ${ }^{113}$ While a few cherubs are present in the composition and twisting out of the vegetative decoration the vast majority of the space is decorated with exquisite stucco vegetation [Figure 4.9]. The walls of the Camarín also include paintings that depict the stories of the Virgin of Ocotlán. The dome is covered in colorful decoration and representations of saints [Figure 4.10]. Loayzaga describes the dome as an admirable abbreviation of heaven. ${ }^{114}$ The careful application of color and gilding of the stucco is similar to what one encounters at La Capilla del Rosario and at Santa María Tonantzintla. Loayzaga acknowledges that Francisco Miguel attains perfection with this Camarín. He states: "It lacks nothing and it needs nothing more."115 The explanations that Loayzaga provides shed light on how Francisco Miguel's art enriches the Camarín with rhetoric. Once an individual enters the Camarín he or she is transported to a different reality, one of heaven and divinity. ${ }^{116}$ Hybrid Baroque artists exercise new kinds of

\footnotetext{
112 Manuel de Loayzaga, Milagrosissima Imágen de Nuestra Señora de Occotlán (Puebla: Imprenta de la Viuda de Miguel de Ortega, en el Portal de las Flores, 1745), 62-63.

113 Ibid., 50-51.

114 Ibid., 50-51.

115 Ibid., 68. (My own translation, see appendix 1 for original text)

116 Kalpan, "Ocotlán y la Estética del Barroco," 58.
} 
expression while simultaneously understanding that the objective of religious art is to serve as an experience for the viewer.

Loayzaga describes with the most admirable words other works by Francisco Miguel like the many retablos he created to decorate the interior of the Santuario de Ocotlán. Sadly none of these retablos survived; the ones currently in place are later additions or replacements. Other creations by Francisco Miguel that are still on display are the wooden table located in the center of the Camarín and the long wooden benches in the Sacristy. ${ }^{117}$ These artworks are worth noting due to the close attention to detail, impeccable carving and evident hybrid iconography. The round wooden table inside the Camarín [Figure 4.11] measures 2.5 meters in diameter. It is decorated with conches and polychrome carved vegetation with a combination of gold, teal and red paint. The legs carry unusual decorations: Francisco Miguel adds monkey caryatids that seem to hold the table [Figure 3.11]. He carved these figurines with precision, as it is evident on the detailed faces. Francisco Miguel had to be aware of the likeness of a monkey and previous representations of this animal to attain this authentic portrayal [Figure 4.12]. Assuming that Spanish Christian priests did not provide this Indigenous artist with a print or visual example of a monkey, a common animal in the

117 Kalpan, "Ocotlán y la Estética del Barroco," 56. 
Americas, for him to copy, the result of this wooden carving comes from Francisco Miguel's own artistic practice and inspiration.

The wooden benches from the Sacristy that Francisco Miguel carved are covered with refined ornamentation [Figure 4.13]. Wherever one looks there are animals, flowers or fruits covering armrests, legs and the backrest. The armrest features similar ape representations to the ones found on the table of the Camarín [Figure 4.14]; the legs hide behind carvings of feathers or scales and the feet end in eagle faces devouring a round element [Figure 4.15]. This carving is interesting since it refers to the pre-Historic iconography of Quetzalcoatl, the feathered serpent Aztec deity. Every detail of this bench is quintessentially Tequitqui. In the 18th century, Francisco Miguel referred to his traditions through his artistic practice. Loayzaga recognized the quality of his art and declared through his testimonies that Francisco Miguel was a master of architecture.

The whole composition of the Camarín, the wooden table and benches in the Santuario de Ocotlán exudes a similar identity to the one found in the Capilla del Rosario in Puebla and to Santa María Tonantzintla in San Andrés Cholula. Tequitqui style is what we encounter in these three structures. The architects and sculptors were all Indigenous and they represented everything with colour, 
vegetation, flowers, fruits and they are all consistent in obsessively filling space with decoration. The representation of angels and cherubs with a different physiognomy captures the identity of these artists. 20th-century Argentinean architect and scholar, Ángel Guido, believed that the representation of a physiognomy that is different to the white male is the result of an aesthetic rebellion from the part of the Indigenous and Mestizo people. ${ }^{118}$ I offer an alternative interpretation to these cherubs. These cherubs or angels seem to illustrate the Indigenous and Mestizo identities within Christianity. This inclusion of their own physiognomy in religious art portrays an embrace of Christianity and a longing to be represented alongside saints and God. Adding to this argument is the presence of portraiture in sculptural decoration [Figure 4.16]. For instance in Santa María Tonantzintla, one can discern that each cherub face is unique and represents individuals of Indigenous or Mestizo origin. Therefore, when these churches or religious spaces are described as Churrigueresque, it affects the context and disregards the authenticity of the hand and identity of the nonWestern artist. Although some elements of the church might be Churrigueresque, as they were built and designed by Spanish architects, it is crucial to separate what is Spanish from what is hybrid or Indigenous. Loayzaga and Palafox y Mendoza were able to differentiate the work made by an Indigenous artist

118 Ángel Guido, "America's Relation to Europe in the Arts," in Baroque New Worlds: Representation, Transculturation, Counterconquest, ed. by Lois Parkinson Zamora and Monika Kaup (Durham, NC: Duke University Press, 2010), 186-187. 
because of its unusual expressive quality and variation in artistic technique. Ultimately these important Spanish figures brought forward the names of Indigenous artists, so why are our current Art history books neglecting them?

The Capilla del Rosario and the Santuario of Ocotlán are two of countless other examples that need further exploration. Another church whose history is still concealed is Santa María Tonantzintla. Although many scholars and travelers focus on the iconographical elements of this church, many other aspects are missing from its history. Who commissioned it? Who designed it? Who are the artists? When was it built? These questions remain unanswered. There is much to be learned from the study of Indigenous and Mestizo artists and their accomplishments. Through their creativity and skill, these artists produced art that fills Mexico's churches from the 17th and 18th centuries with a hybrid style. If their talents were the source of inspiration for Spanish artists then there are years of research left in this field. One must investigate further the role of Indigenous and Mestizo artists in the colonies, re-examine early modern globalization and the cultural outcomes of colonialism. 


\section{Conclusion}

\section{$\underline{\text { Revisiting Mexican Hybrid Baroque Art History and its Global Impact }}$}

The 17th and 18th centuries witnessed innovative global artistic currents. In the Americas, Mestizo and Indigenous architects and sculptors established the foundation of a modern and diverse Baroque attitude that resulted in a hybrid mode of representation. Mexican Hybrid Baroque presented Tequitqui style to the world beginning in the 16 th century and continued to express a cross-cultural connection through art until the 18th century. Spanish architects, friars and bishops among other commentators, were drawn to this new style and recognized that it exuded an identity and artistic technique that differed from their own. What is fascinating is that 20th-century scholars presume that Mexican Baroque Mestizo and Indigenous style is localized within Spanish Baroque churches. Although most literature covers the usual discourse of Spain shaping Mexican culture due to the conquest, we ought to revisit the cultural impact of colonialism and consider cross-cultural rather than uni-directional consequences. Through the study and analysis of Mexican Hybrid Baroque sculpture and architecture I challenged the archetypal Western discourse and proposed that Tequitqui art and the non-Western artists who created it deserve acknowledgment in the literature of Baroque Art history and globalization. 
To embark on the discussion of Mexican Hybrid Baroque it is necessary to reiterate that there are major differences between Spanish Baroque in Mexico and Mexican Baroque. Mexico City, for instance, has many fine examples of Spanish Baroque style [Figures 2.6, 3.1, 3.2]. The architecture and sculpture that still stands in this city was designed in totality by Spanish architects and carries the contemporary Baroque artistic style of the crown known as Churrigueresque [Figures 2.2-2.4]. The Metropolitan Cathedral of Mexico City holds the Retablo de los Reyes and Retablo del Perdón [Figures 3.1-3.2]. These retablos are major models of the Spanish Baroque style since they carry estípites, golden ornamentation and wooden sculptures in the estofado technique. Numerous examples of this kind still remain in Mexico City, and they are all in the Spanish Baroque style.

However, once outside of Mexico City, the Mexican architectural landscape saw a change in artistic style. Indigenous and Mestizo architects and sculptors were able to deviate from the Spanish style to represent Christian idioms in their own way. Three elements affect this change in representation: firstly, artist training was unlike the academic training received by the Spanish artists. Secondly, the cultural changes that colonialism brought stimulated the creation of a new identity for Indigenous and Mestizo artists that inevitably affected their 
work. Lastly, many of the Christian representations, such as blood, water and flowers were already familiar concepts to the Indigenous artist; therefore their approach and understanding of Christian images was different from how the Spanish interpreted the same images. These elements compose the foundation of a hybrid style that was developed by Indigenous and Mestizo artists outside Mexico City in places such as Querétaro, Puebla and Tlaxcala among many others.

In New Spain holding the title of architect entailed different things. If one knew how to be a bricklayer, a master builder or had acquired general knowledge of architecture and geometry, one was considered an architect. Ordinances were placed after 1746 indicating that those who carried the title of 'maestro de albañilería' or 'bricklayer master' would now be considered 'professional architects.' ${ }^{119}$ Although these were effective laws to protect members of the guild, these specifically excluded Indigenous and Mestizo artists from the profession. ${ }^{120}$ These debarred artists were forced to learn their trade from other architects and sculptors by attending artist studio lessons. They did not receive academic instruction or proper training in their trade like Spanish architects did; instead they learned in alternative ways, which evidently affected the product of their artistic practice.

119 Fernández, "El Albañil, El Arquitecto y el Alarife en la Nueva España," 55-56. 120 Toussaint, Colonial Art in Mexico, 278. 
Art in all of its forms is undeniably shaped by the identity of the artist. The art produced by the artist is theoretically inseparable from his/her own identity. Therefore cultural changes that affect artists (i.e. religion, politics or society) consequently influence the product of their practice. ${ }^{121}$ Mexican Hybrid Baroque style is a reflection of artists who molded art through the application of native skills and their personal interpretation of Christian idioms. Even if Spanish architects designed a church, it seems highly unlikely that they controlled the hybrid result. At the crossroads of colonialism, Indigenous and Mestizo artists were challenged to create their own identity, one that connected them to their ancestry and to their new religion. ${ }^{122}$ The creativity of Indigenous and Mestizo architects and sculptors is displayed in countless churches that decorate, in a hybrid style, the Mexican landscape today.

Since the 16th century, Indigenous artists were exposed to Christian images through books, prints and drawings transported to New Spain by Franciscan and Dominican friars. In an effort to convert the population of this new colony into Christianity, friars would learn the ethnic languages and traditions of the Indigenous populations. To ensure a profound comprehension of

121 Reyes-Valerio, Arte Indocristiano, 107.

122 Fernández, Cosmopolitanism in Mexican Visual Culture, 32. 
Christian values and biblical stories, friars encouraged the reading and constant copying of Christian images. ${ }^{123}$ What the friars did not expect was that the Christian images of (blessed) water, blood (of Christ) and flowers were already familiar to the Indigenous artists [Figures 2.12, 2.13, 2.16]. These images were not exclusive to the Western world; therefore the Indigenous artists established a connection between the new idiom presented to them by the friars and the native illustration of the same element. The result of this connection, concurrently with Indigenous artistic skills, is a hybrid representation and style. This hybridity is described by a Náhuatl term known to scholars as Tequitqui, which refers to the artistic outcome of the blending of two cultures. Tequitqui style begins in the 16th century and continues into the 17 th and 18 th centuries, as I made evident throughout this thesis by exploring several examples of Baroque churches located outside Mexico City.

Important characters in history recognize the evident deviation in style and value of Mexican art in the 17th and 18th centuries. Juan Palafox y Mendoza, a highly regarded figure and connoisseur of art, demonstrates an vested interest in the work of the Indigenous and Mestizo artists. He composed a treatise in 1671 to the attention of King Phillip IV in which he defends the rights and virtues of the Indigenous population of Mexico. In the sixteenth chapter of his treatise, Palafox y

123 Reyes-Valerio, "El Arte Indocristiano o Tequitqui," 708. 
Mendoza says "[t]he comprehension and tact to understand any trade, as difficult as it may be, is strange and [in this regard] I do not doubt [the Indigenous tradesmen] surpass all nations..." $124 \mathrm{He}$ commends the techniques and abilities of the Pueblan Indigenous artists, saying that, at times, their techniques outshine those of any nation. ${ }^{125}$ Similarly Franciscan priest Manuel de Loayzaga provides testimony of Fransisco Miguel Tlayoltehuanitzi, a Tlaxcaltecan Indigenous architect who decorated the interior of the Santuario de Ocotlán in Tlaxcala. Loayzaga wrote a book devoted entirely to this church, its history, Francisco Miguel's story and a detailed description of his artwork. A large part of this text is dedicated to the understanding and veneration of the Camarín decorated by Francisco Miguel. Loayzaga believes this room does not compare to any European creation he had encountered in the past. Loayzaga says "[n]ow that the Camarín is finished, not even the most successful Masters or Officials could be less than overwhelmed [by the finished product], and with reason: because even if the most famous sculptures in Naples were to be placed face to face with the least finished sculpture in the Camarín, [the Italian sculptures] would cover their faces in shame [of being outshined]."126 It is unmistakable that Francisco Miguel

124 Palafox y Mendoza, De la Naturaleza y Virtudes del Indio, 41. (My own translation, see appendix 1 - Chapter Three \#95 - for original text).

125 Salcedo Izu, "Palafox, Defensor de los Indios," 278.

126 Loayzaga, Milagrosissima Imágen de Nuestra Señora de Occotlán, 62-63 (My own translation, see appendix 1 for original text). 
implemented a new expression and understanding of Christian idioms while at once creating a religious experience for the viewer.

Both Palafox y Mendoza and Loayzaga understood and appreciated the novelty of Tequitqui style that was implemented to church decoration by Indigenous and Mestizo architects. Having visually influenced these important Spanish figures, one can hypothesize that this style must have traveled abroad and beyond the Mexican borders. Since pre-Hispanic items traveled to Spain and were awe-inspiring to many Europeans in the 15th and 16th centuries, it is plausible that somewhere in the archives of Mexico and Spain one can encounter prints, drawings or sketches of Tequitqui style in Spain. Although this project focuses on providing written testimonies as proof of cross-cultural exchanges there is a possibility that visual evidence also exists. Nonetheless one must consider the statements made by Ángel Guido and Pedro Henríquez Ureña that lead scholars towards a new wave of research. Both believe that there is a clear Mexican Mestizo style found in Spanish churches.

Guido $^{127}$ and Henríquez Ureña ${ }^{128}$ point to an important proposition by suggesting that Mexican Hybrid Baroque style is found in Spanish architecture.

127 Ángel Guido, “America's Relation to Europe in the Arts,” 187. 
Understanding Tequitqui as a style that had cross-cultural visual effects and acknowledging the work of Mestizo and Indigenous artists during the 17th and 18th centuries is important to the re-examination of Mexican Baroque Art History. If Mexican Hybrid Baroque influenced Spanish visual culture, it is necessary to re-evaluate the cultural outcomes of colonialism and to incorporate the names of the artists who created Mexican Hybrid Baroque art into history.

Language plays a significant role in this matter. In Mexican Hybrid Baroque literature, this style is often described with Western terms that refer to Spanish architectural styles (i.e. Churrigueresque and Plateresque). This project discussed the use of language providing meaning to art as a predicament in writing Art history. Western terminology is used on a regular basis to describe and label Western and non-Western art alike. In this case the use of Spanish terms to describe Mexican Hybrid Baroque art decontextualizes its history and neglects the identity of the Indigenous and Mesitzo artists. Therefore it is necessary to revisit the use of Western language to refer to non-Western art as it has a direct effect on the context and history of art. A proposed starting point is the use of the term Tequitqui, which originates from Náhuatl, a native ethnic language of Mexico and, as previously mentioned, it denotes the outcome of the

128 Pedro Henríquez Ureña, "Baroque in America", in Baroque New Worlds: Representation, Transculturation, Coutnerconquest, ed. by Zamora Parkinson et al. (Durham: Duke University Press, 2010), 200. 
cultural encounter of two different cultures. ${ }^{129}$ This term describes Mexican Hybrid Baroque art and although some scholars believe this word can only be used to refer to 16th-century architectural decoration in stone,130 it is applicable to future centuries as well. The continued use of Tequitqui to refer to Mexican Hybrid Baroque sculptural decoration on architecture in the 17th and 18th centuries is conducive to benefitting its context and history.

Spanish Baroque Architecture is the result of a conglomeration of a variety of cultures and styles including Gothic, Renaissance, Italian Baroque, Austrian and Moorish designs. ${ }^{131}$ The propensity to the influence of other cultures provides reasonable grounds for the assimilation of Mexican Hybrid Baroque style into Spanish architecture. As previously discussed Mestizo and Indigenous artists who shaped Mexican Hybrid Baroque art influenced the visual culture of Spanish viewers in the 17th and 18th centuries. ${ }^{132}$ The blending of cultural and religious elements, traditions and iconography produced a hybrid, and therefore, an intercultural style. The plausible cultural impact of Mexican Hybrid Baroque style in Spain adds layers of historical value and introduces Mexican Baroque Art History into dialogues of early modern era globalization.

${ }_{129}$ Reyes-Valerio, "El Arte Indocristiano o Tequitqui," 710.

130 Reyes-Valerio, Arte Indiocristiano: Escultura en el Siglo XVI en México, 140.

131 Weisbach, Spanish Baroque Art, 13-19.

132 Vargaslugo, México Barroco, 13-14. 
As defined by Felicity Nussbaum, globalization "is the result of historical processes whose histories trace back to [the] eighteenth century."133 The colonial period witnessed the beginning of an intercultural exchange of commerce, ideas and art. This trade allowed colonized cultures to become empowered societies that can create and build upon new ideas and styles. Although the conventional discourse of globalization only includes a uni-directional global impact during colonialism, it is evident that this phenomenon is rather cross-cultural and multidirectional. This resonates particularly in 17th and 18th centuries in Mexico as Tequitqui style had a visual impact on Spanish artists and art connoisseurs. This project centered its attention on investigating the cross-cultural quality of hybrid artistic products that reinvent the traditional dialogues of early modern globalization.

Moreover, following Guillermo Tovar y de Teresa's definition of the Baroque as "a compound of attitudes and artistic manifestations in the West,"134 artists like Francisco Miguel performed a Baroque attitude in their artistic practice. Through the overwhelming levels of decoration, he created rhetorical spaces where viewers could be transported to another spiritual reality. Mestizo

133 Nussbaum, The Global Eighteenth Century, 6.

134 Cortés Rocha, El Clasicismo en la Arquitectura Mexicana, 24 (My own translation, see appendix 1 - Chapter One, \#7 - for original text). 
and Indigenous artists understood the purpose of art during the 17th and 18th centuries and provided the audience with unique ecclesiastical spaces where an individual could connect with the space at an emotional level. This is evident upon entering the Capilla del Rosario, Santa María Tonantzintla, and the Camarín of the Santuario de Ocotlán among many other Mexican Hybrid Baroque examples. The histories and identities of the artists are therefore critical aspects of Mexican Baroque Art History, one that requires revisiting.

The focus of the Western discourse of Art history is on art and artists who shaped the Western and non-Western worlds, but it fails to acknowledge that the opposite is also possible. The research done for this project aimed to contribute to the literature of Mexican Art history and challenge accepted perspectives on the cultural impact of colonialism. The current absence of recognition of Mestizo and Indigenous artists in Mexican Baroque Art history is an aspect that should also be re-examined. The inclusion of artist names and accomplishments into history books will only enrich the already large heritage and cultural histories of Mexico. Moving forward this thesis could be a stepping-stone to a much larger research venture. Identifying Mexican Mestizo and Indigenous styles abroad, and finding hard visual evidence of this cross-cultural exchange, especially in Europe, will corroborate the argument that a uni-directional stance on the cultural outcomes of the colonial era requires pressing re-evaluation. This re-assessment 
provides an opportunity for scholars to challenge the Western Art history canon and review the artistic affects of non-Western cultures on Western art once more. 


\section{APPENDIX ONE | Illustrations}

\section{INTRODUCTION}

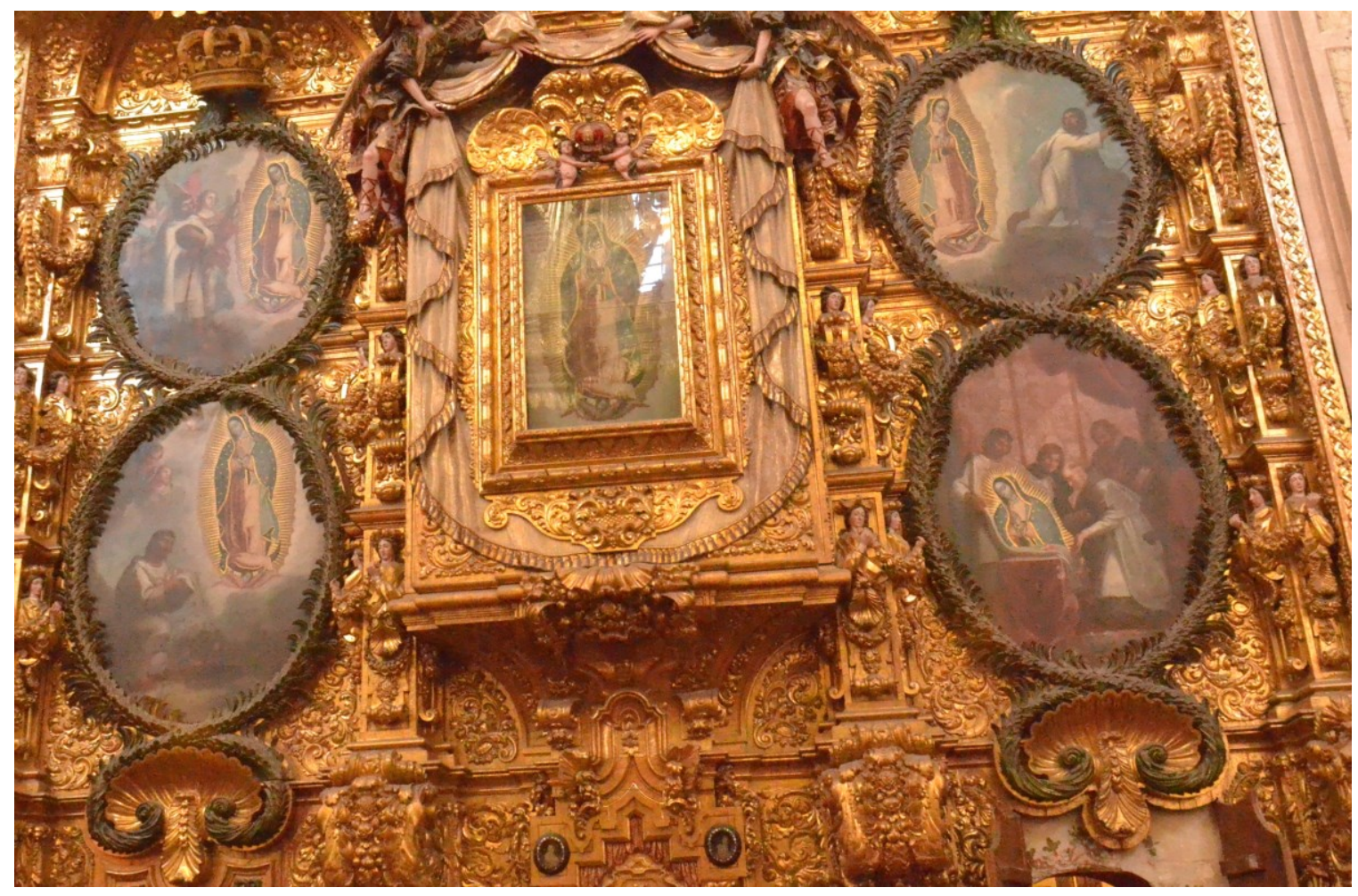

[Fig. 1.1 Paintings by Miguel Cabrera in Church of Santa Rosa, Querétaro, 18th Century] 


\section{CHAPTER ONE}

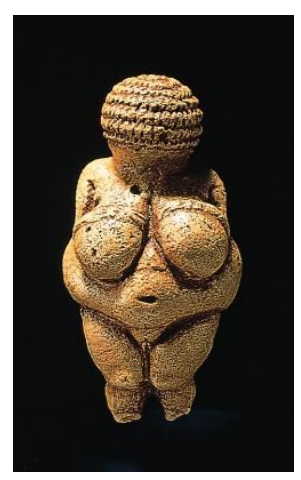

[Fig. 2.1 Venus of Willendorf, ca.30,000 BCE]

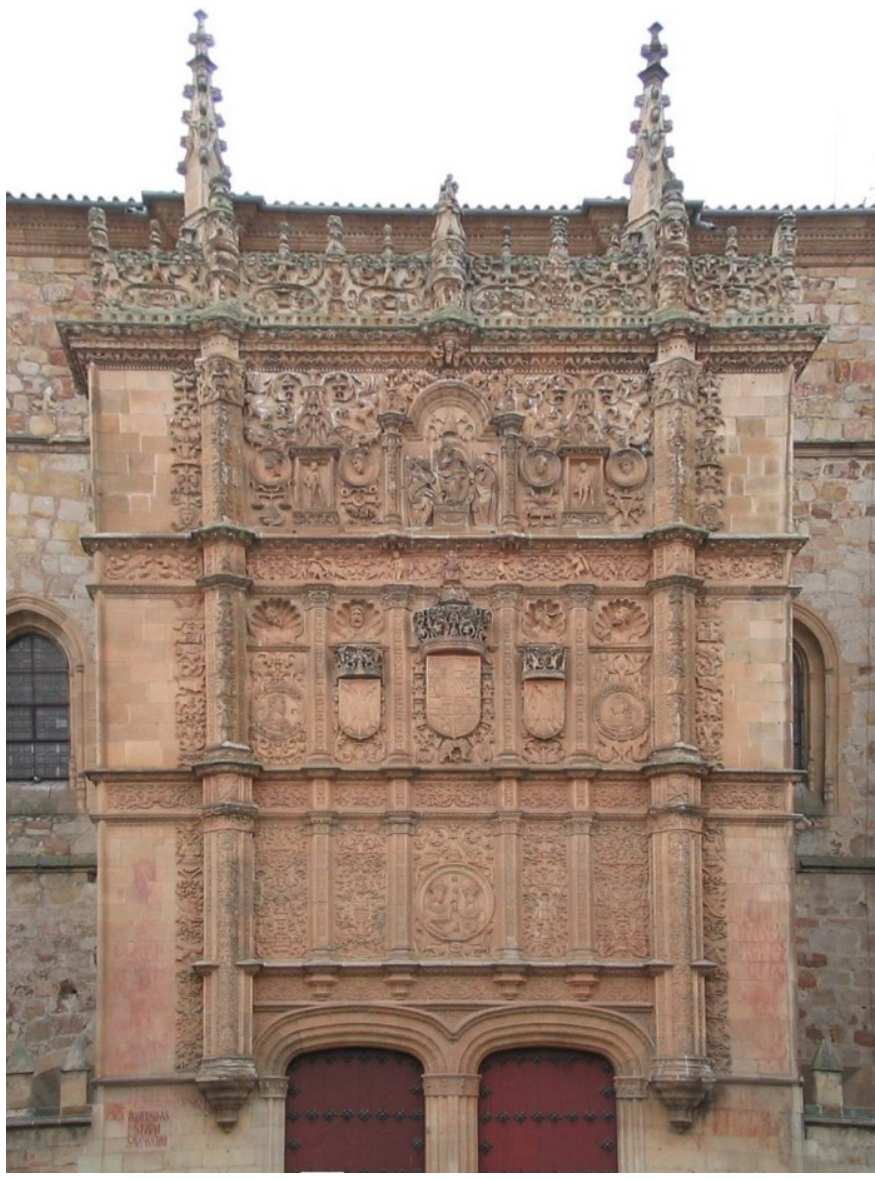

[Fig. 2.2 Universidad de Salamanca, Spain] 


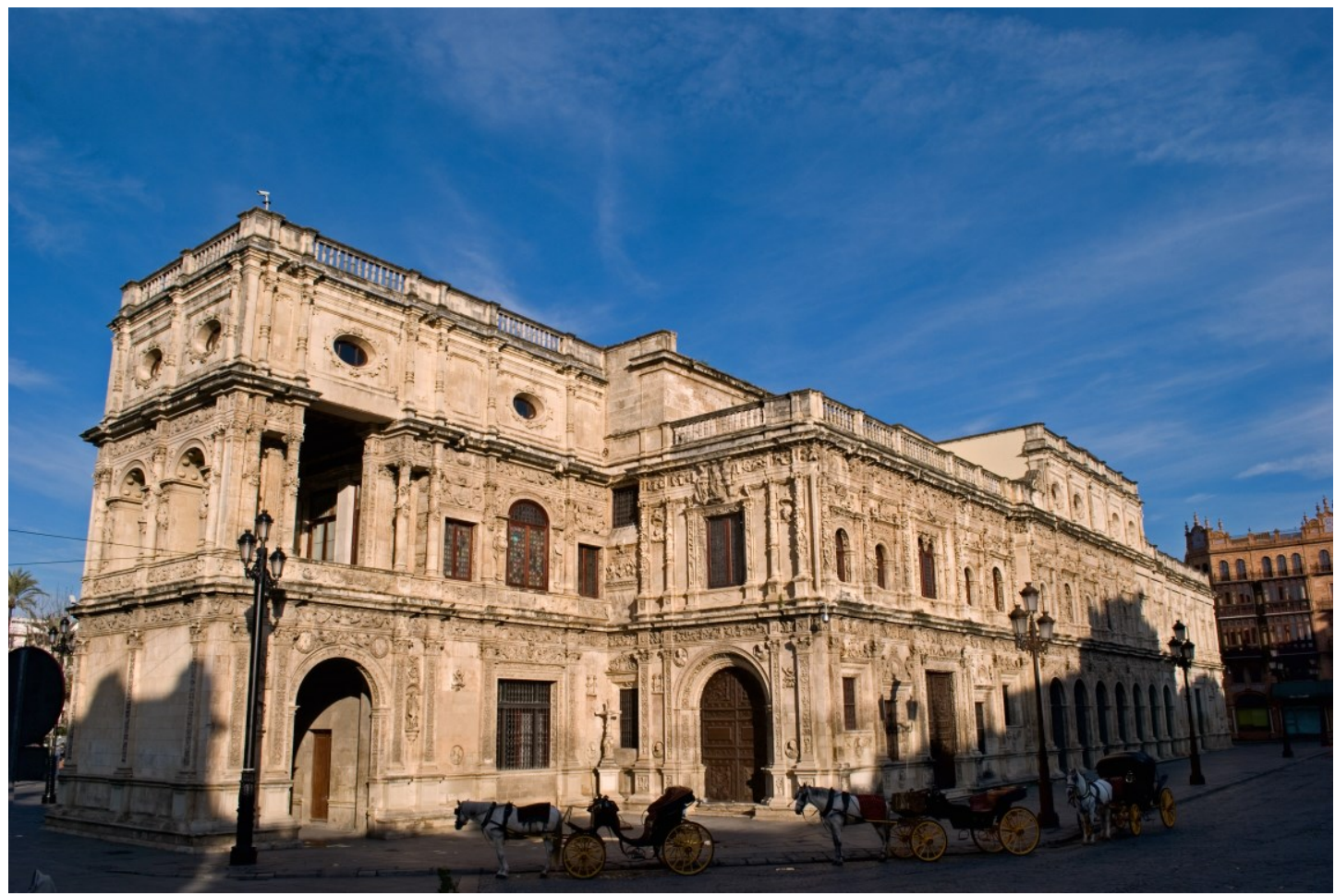

[Fig. 2.3 Ayuntamiento de Sevilla, Spain] 


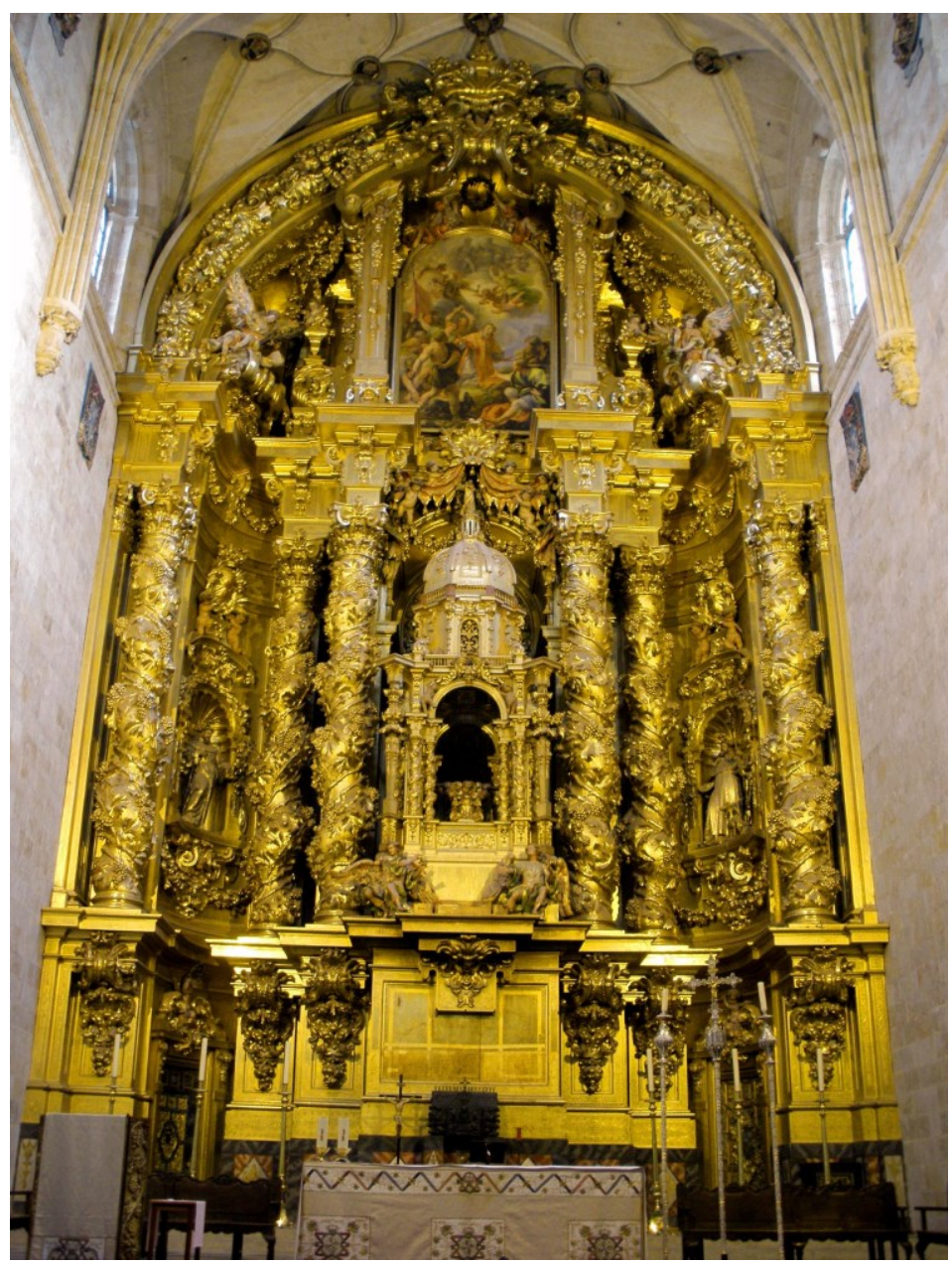

[Fig. 2.4 Convento de San Esteban, Salamanca] 


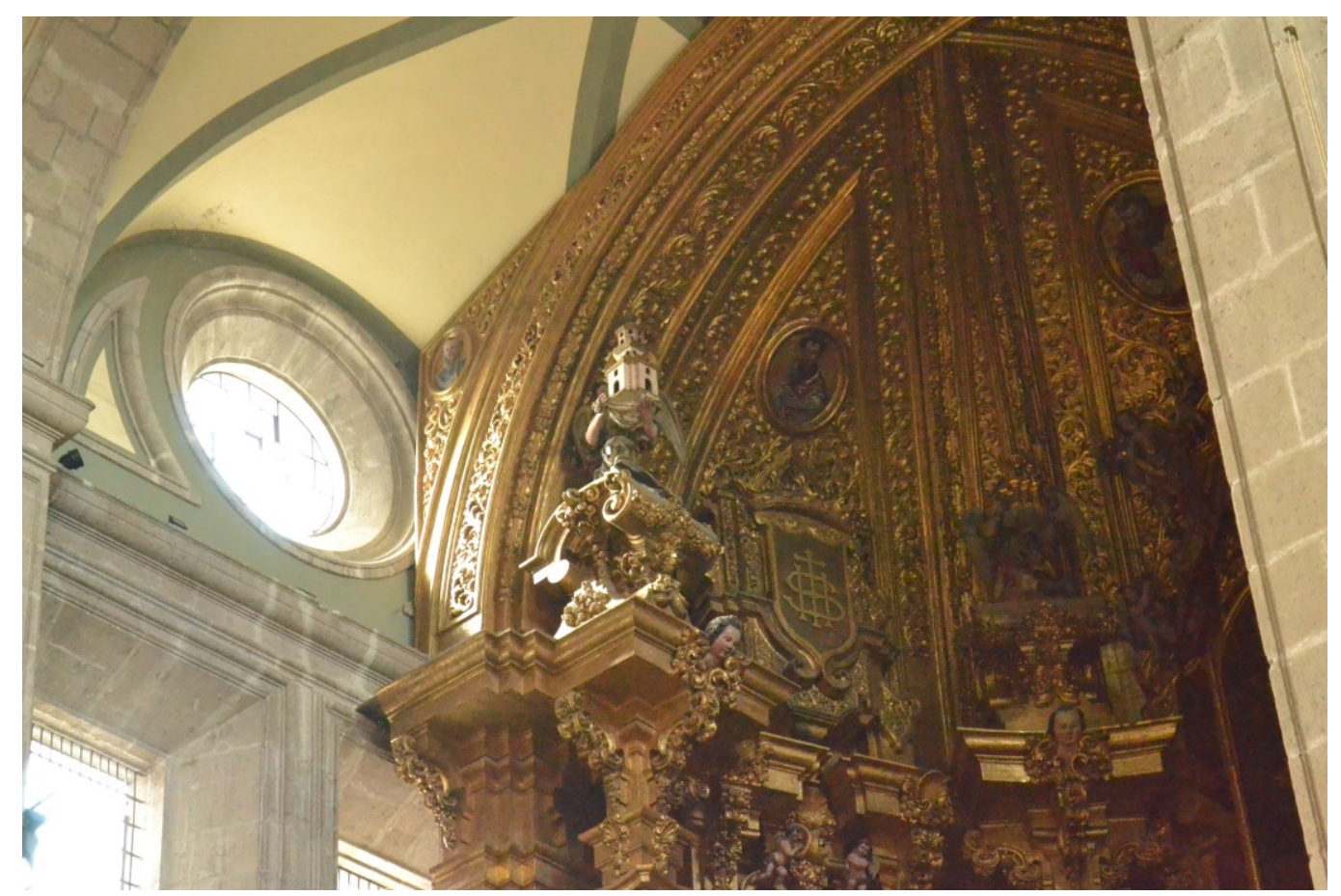

[Fig. 2.5 Detail of the Retablo del Perdón in the Metropolitan Cathedral of Mexico City]

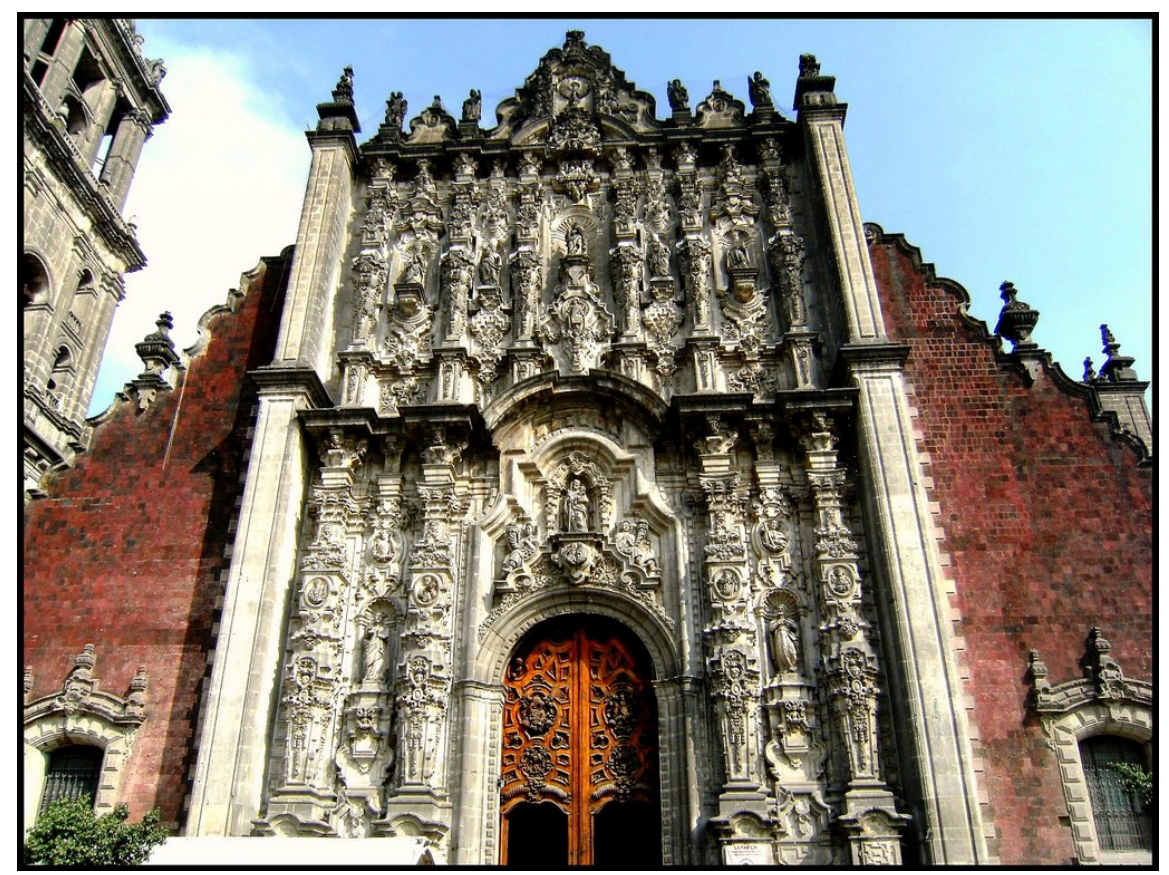

[Fig. 2.6 Sagrario Metropolitano, Mexico City] 


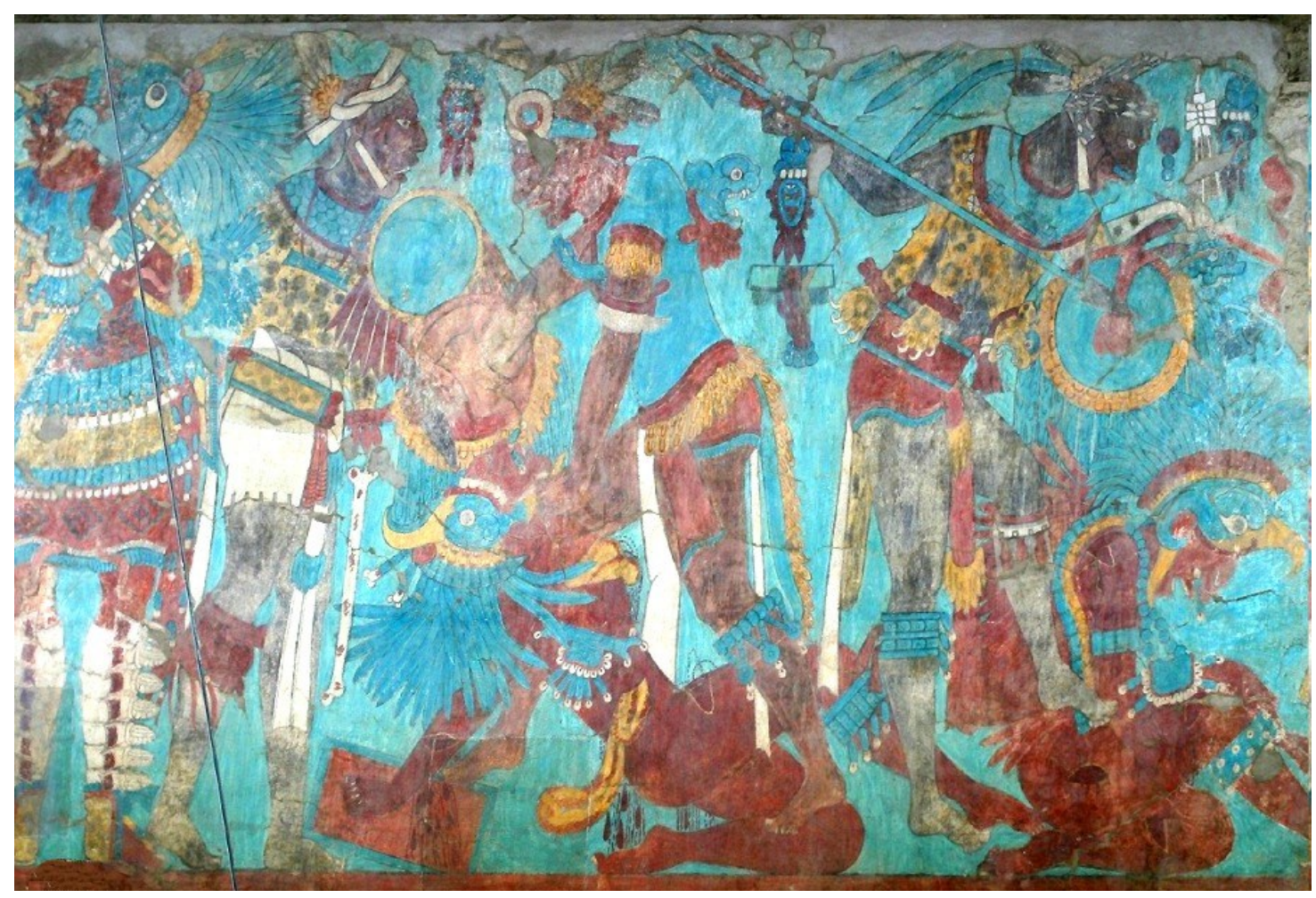

[Fig. 2.7 Cacaxtla Mural, Tlaxcala] 


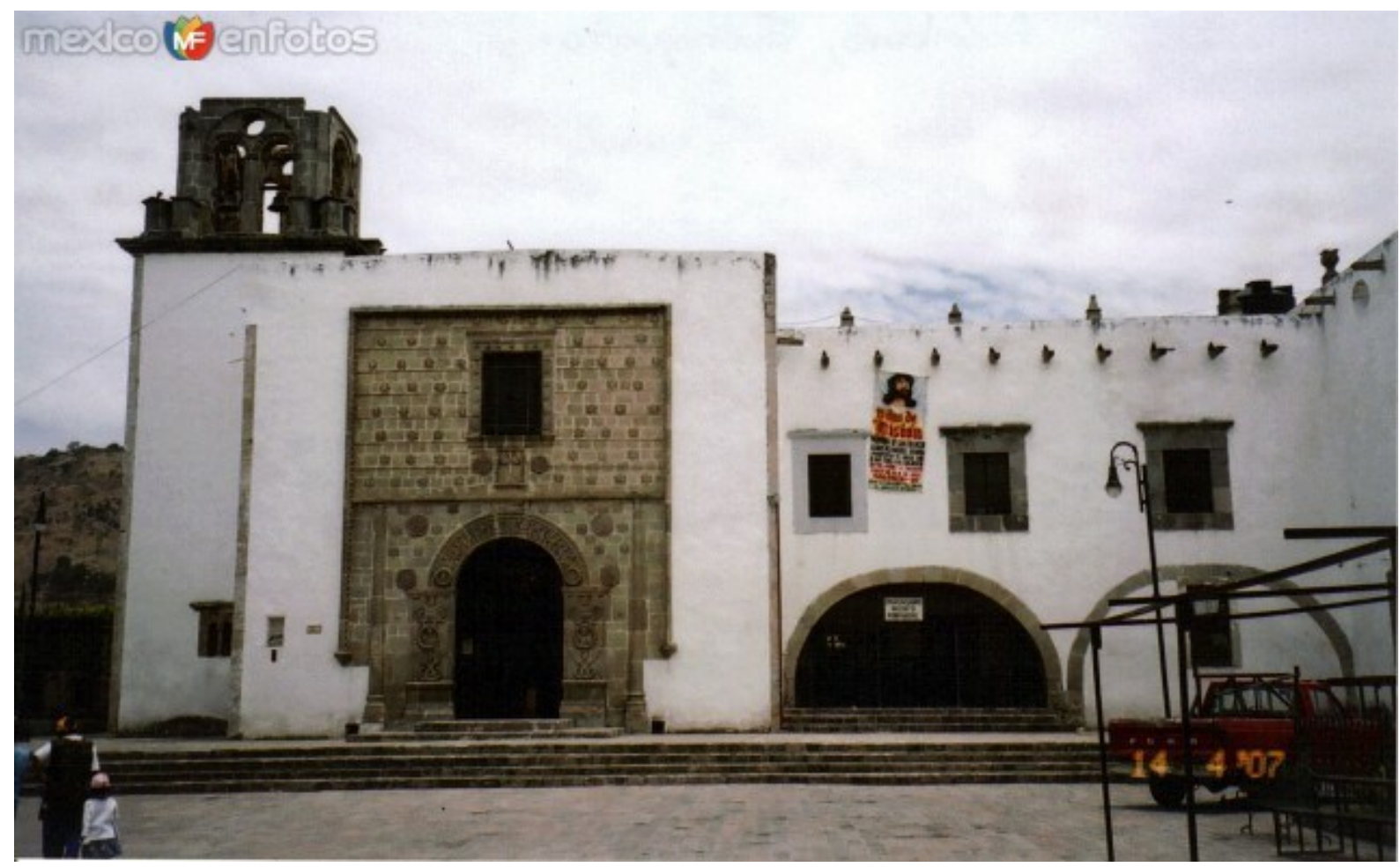

[Fig. 2.8 Hospital of Acámbaro, Guanajuato, Mexico] 


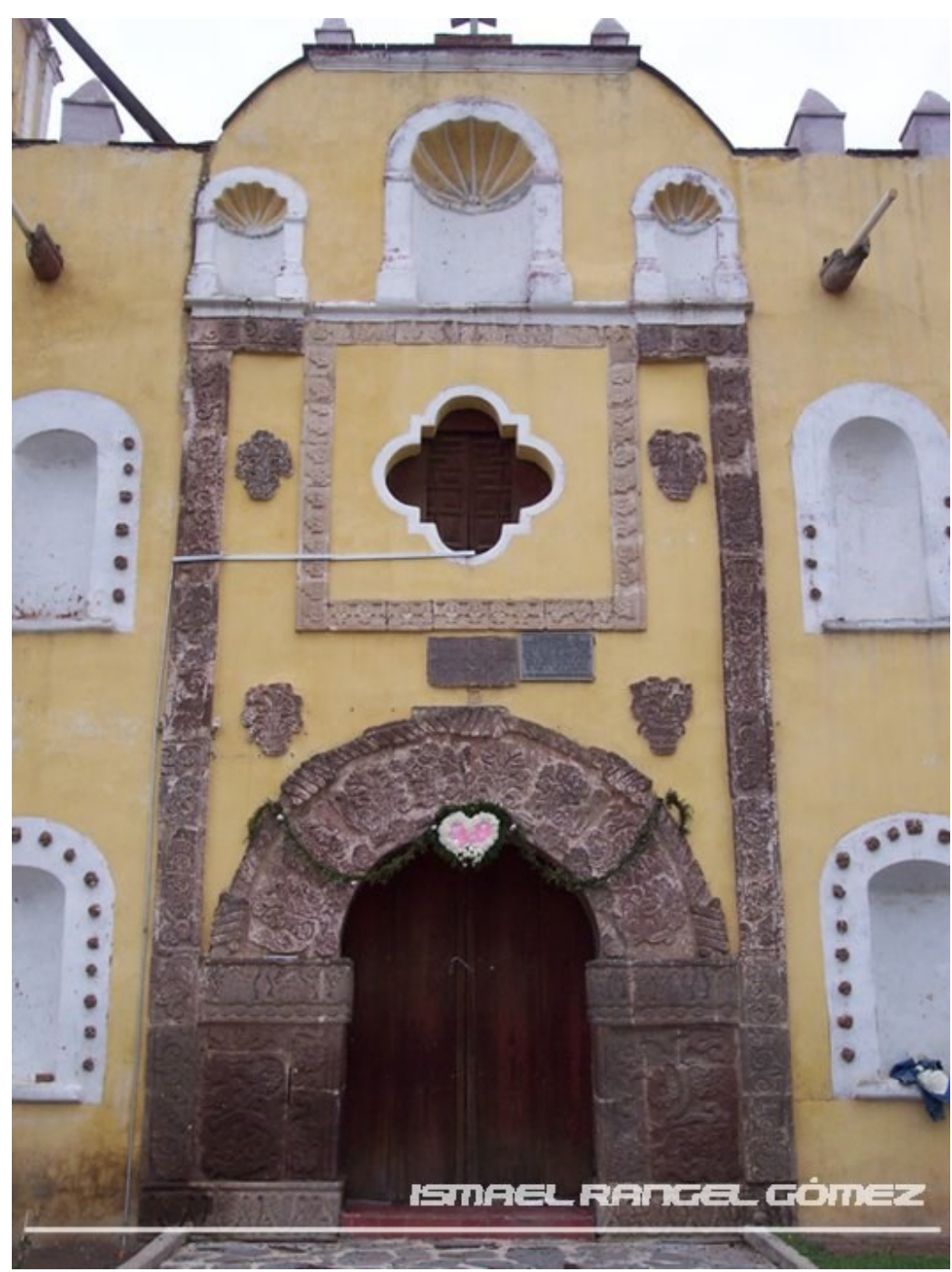

[Fig. 2.9 Temple of Santa Mónica, Hidalgo, Mexico] 


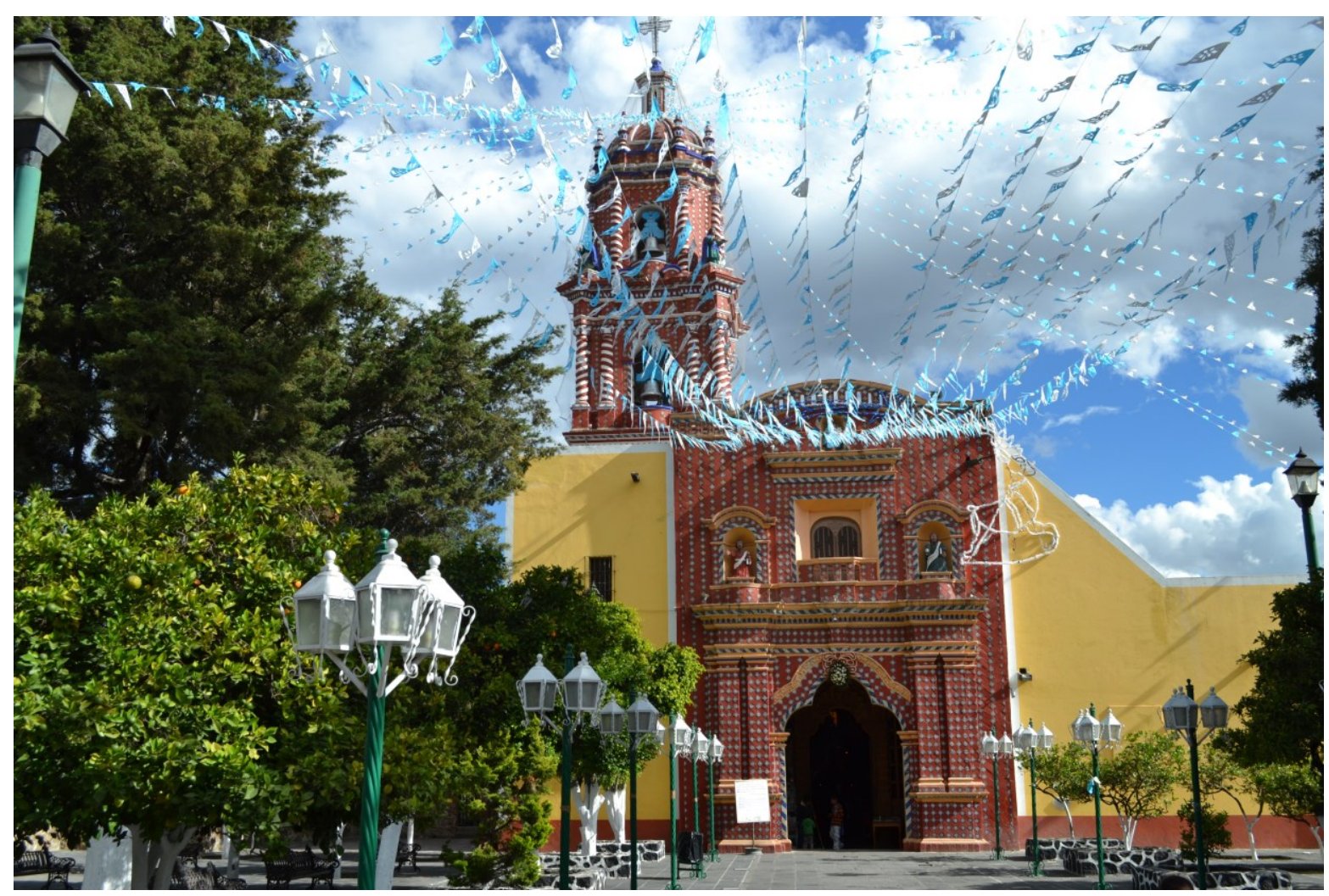

[Fig. 2.10 Façade of Santa María Tonantzintla, Puebla, Mexico] 


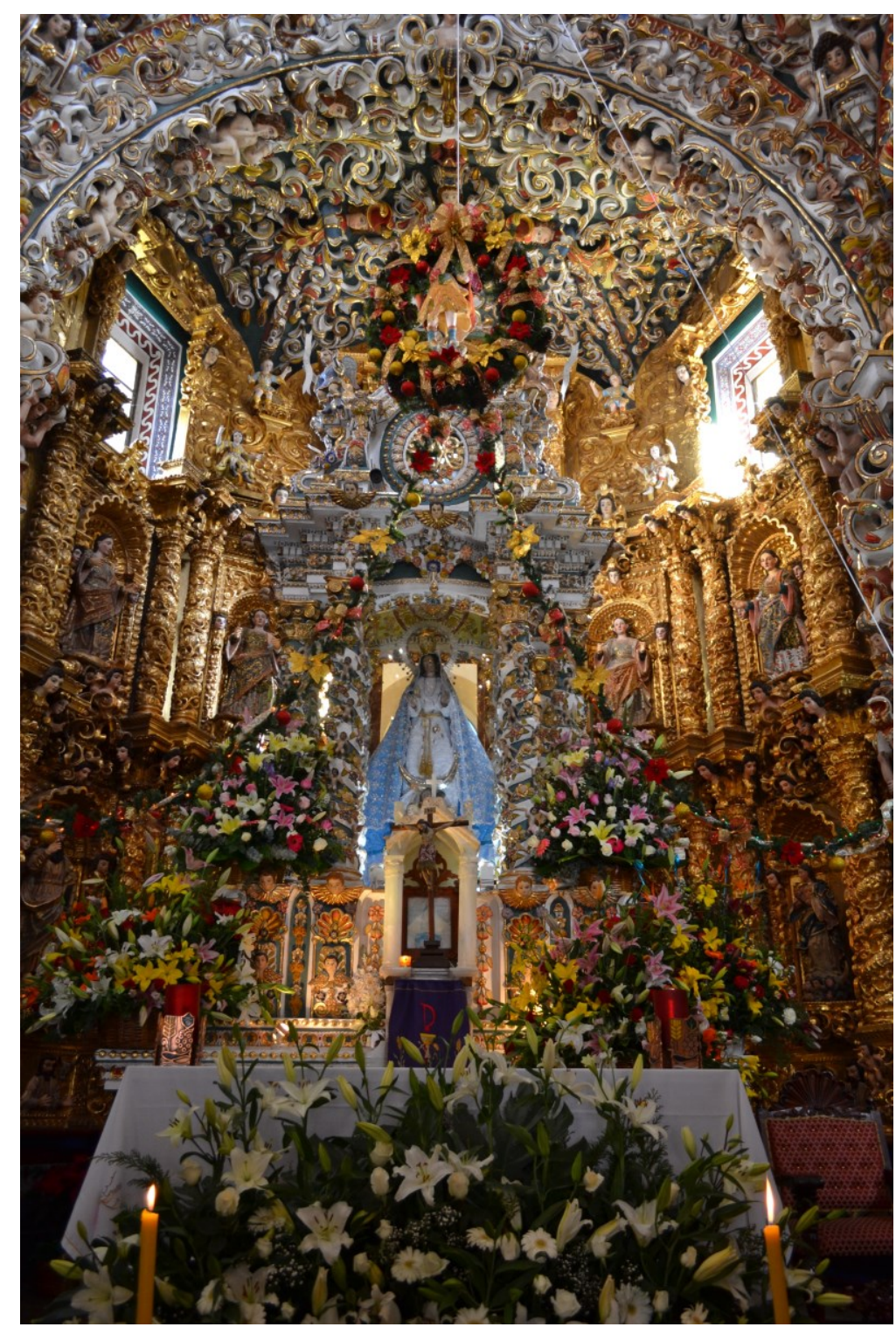

[Fig. 2.11 Interior of Santa María Tonantzintla, Puebla, Mexico] 


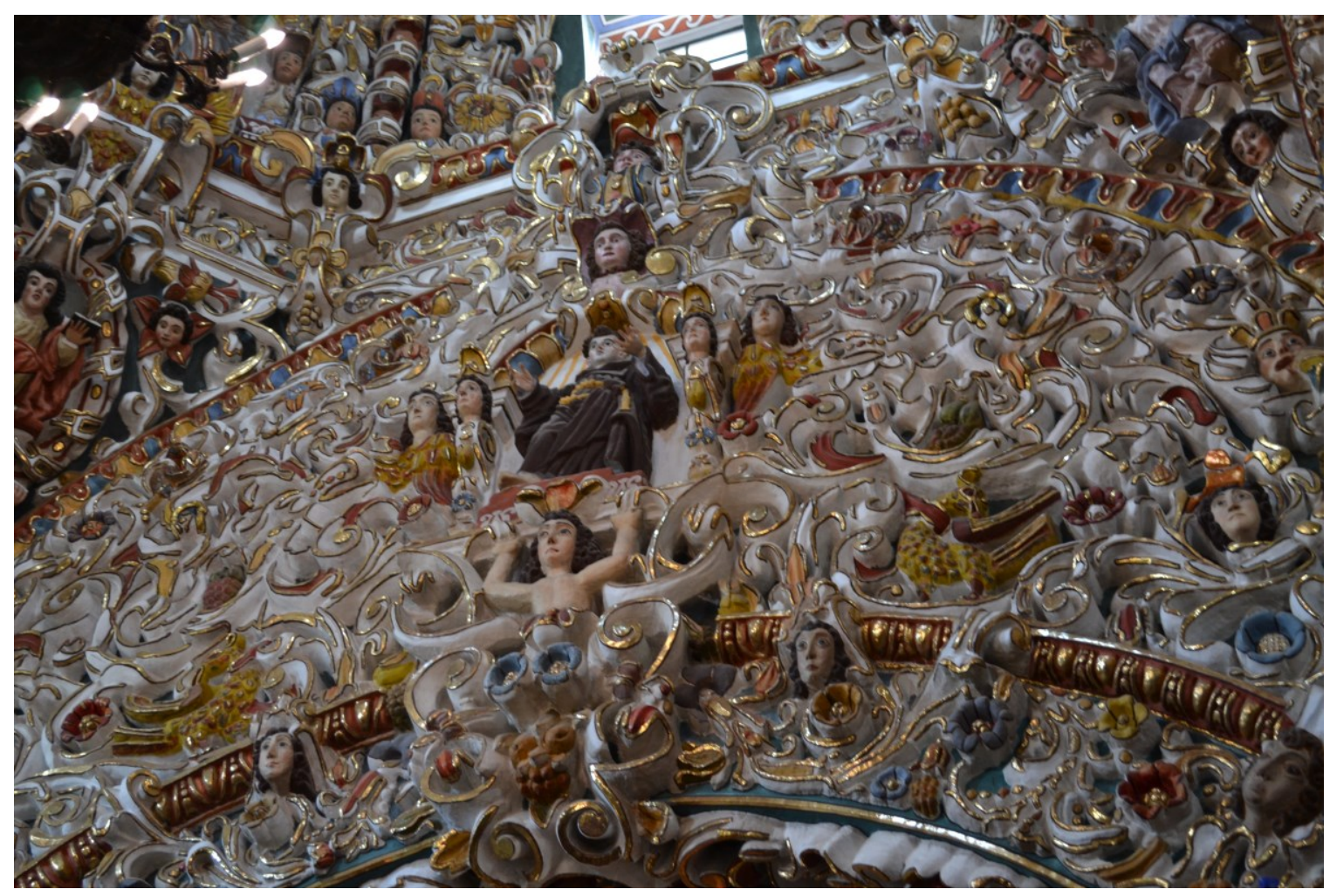

[Fig. 2.12 Detail of the interior of Santa María Tonantzintla, Puebla, Mexico] 


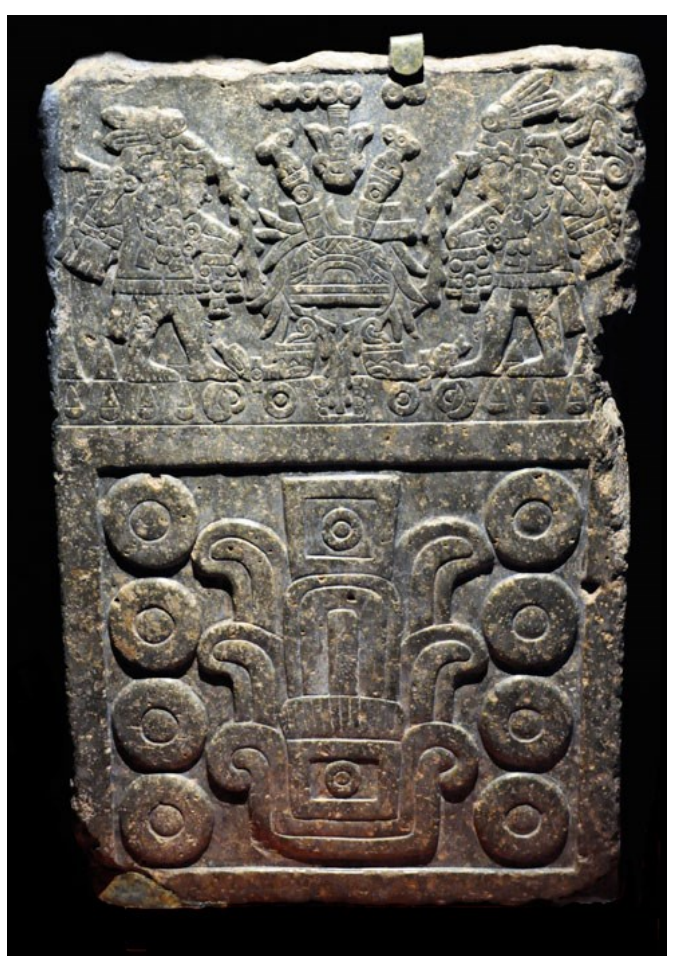

[Fig. 2.13 Aztec stone carving]

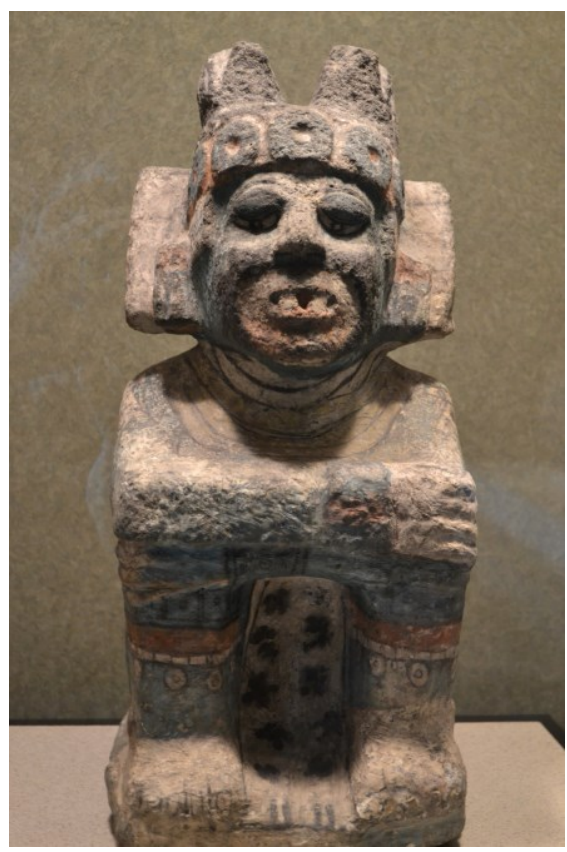

[Fig. 2.14 Aztec stone polychrome sculpture] 


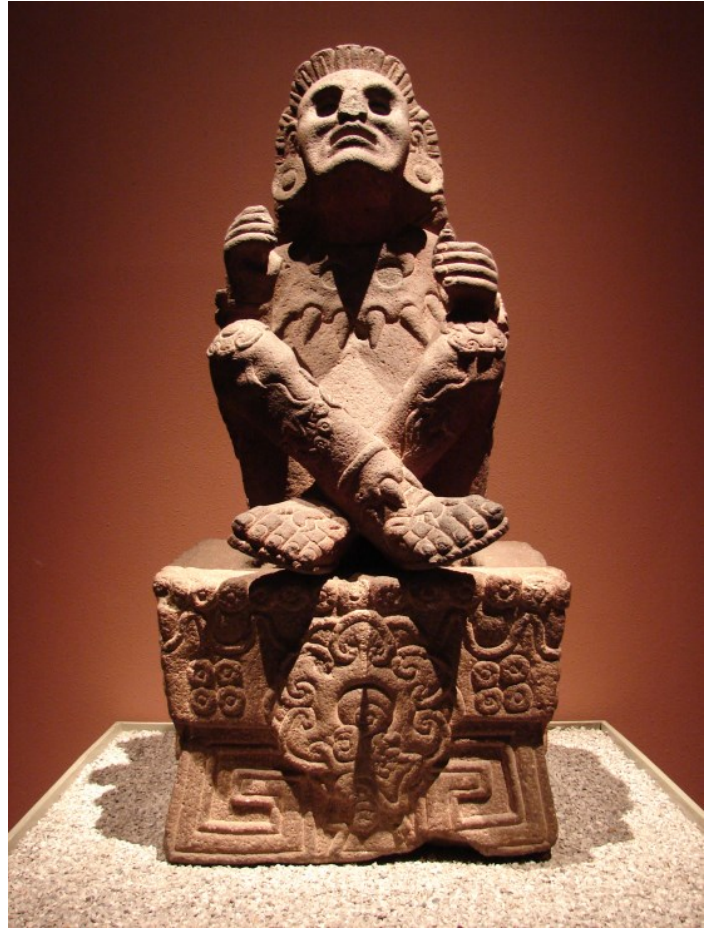

[Fig. 2.15 Aztec stone sculpture of God Xochipilli]

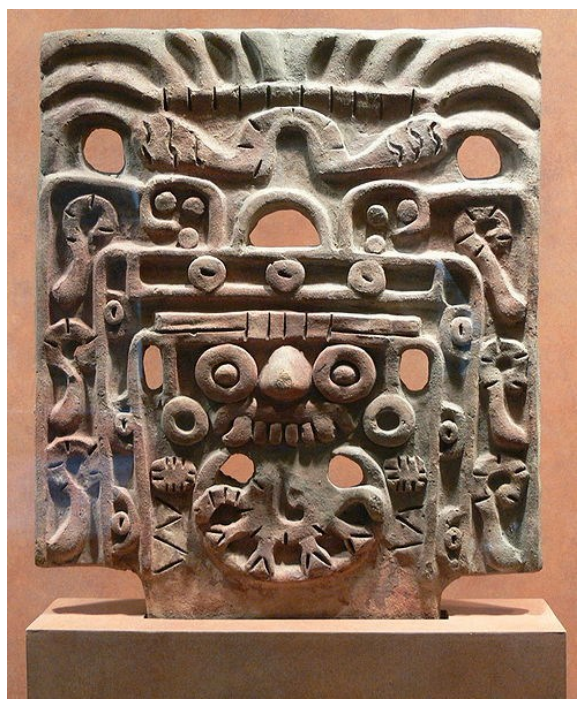

[Fig. 2.16 Aztec stone sculpture of God Tláloc] 


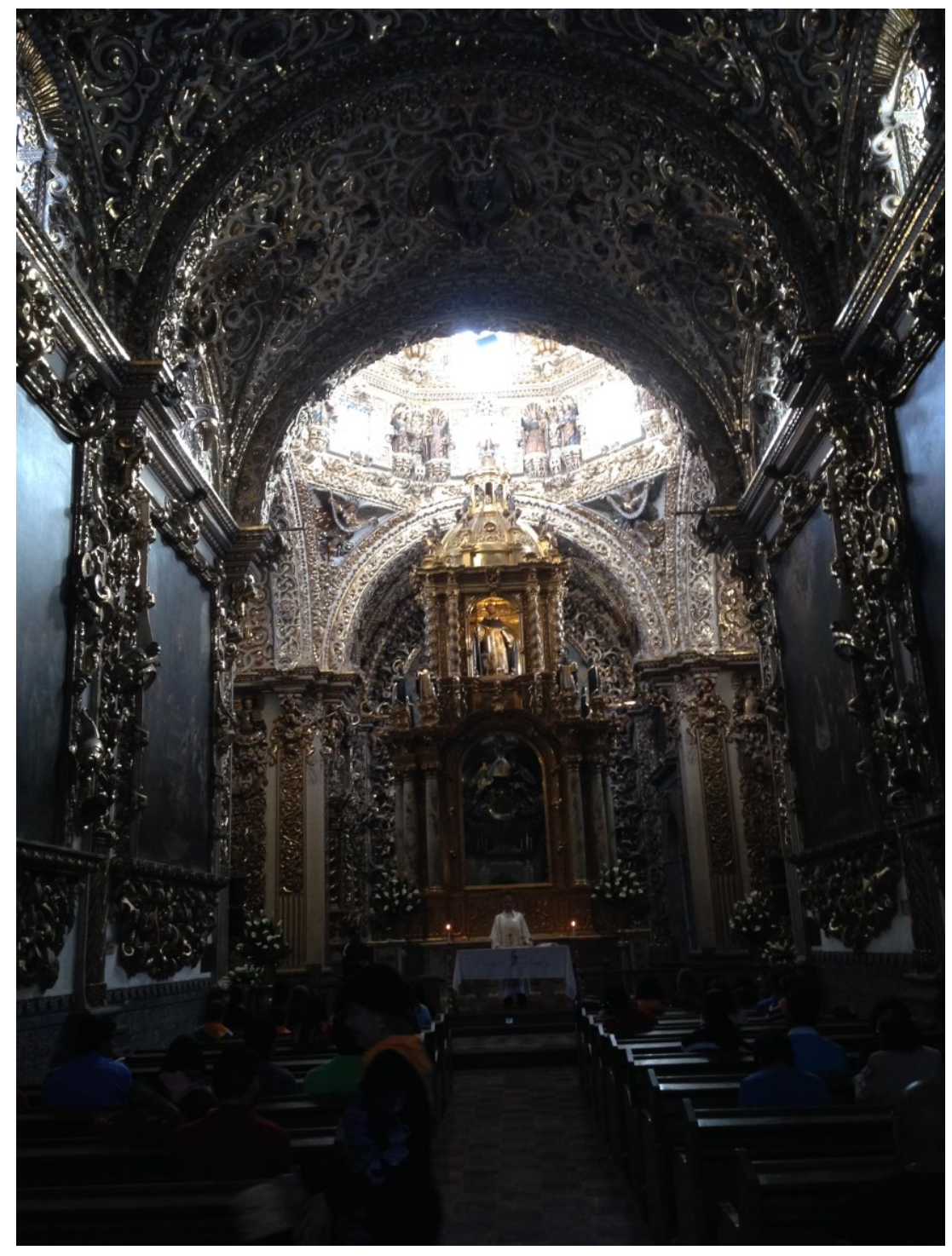

[Fig. 2.17 Interior of

Capilla del Rosario, Puebla] 


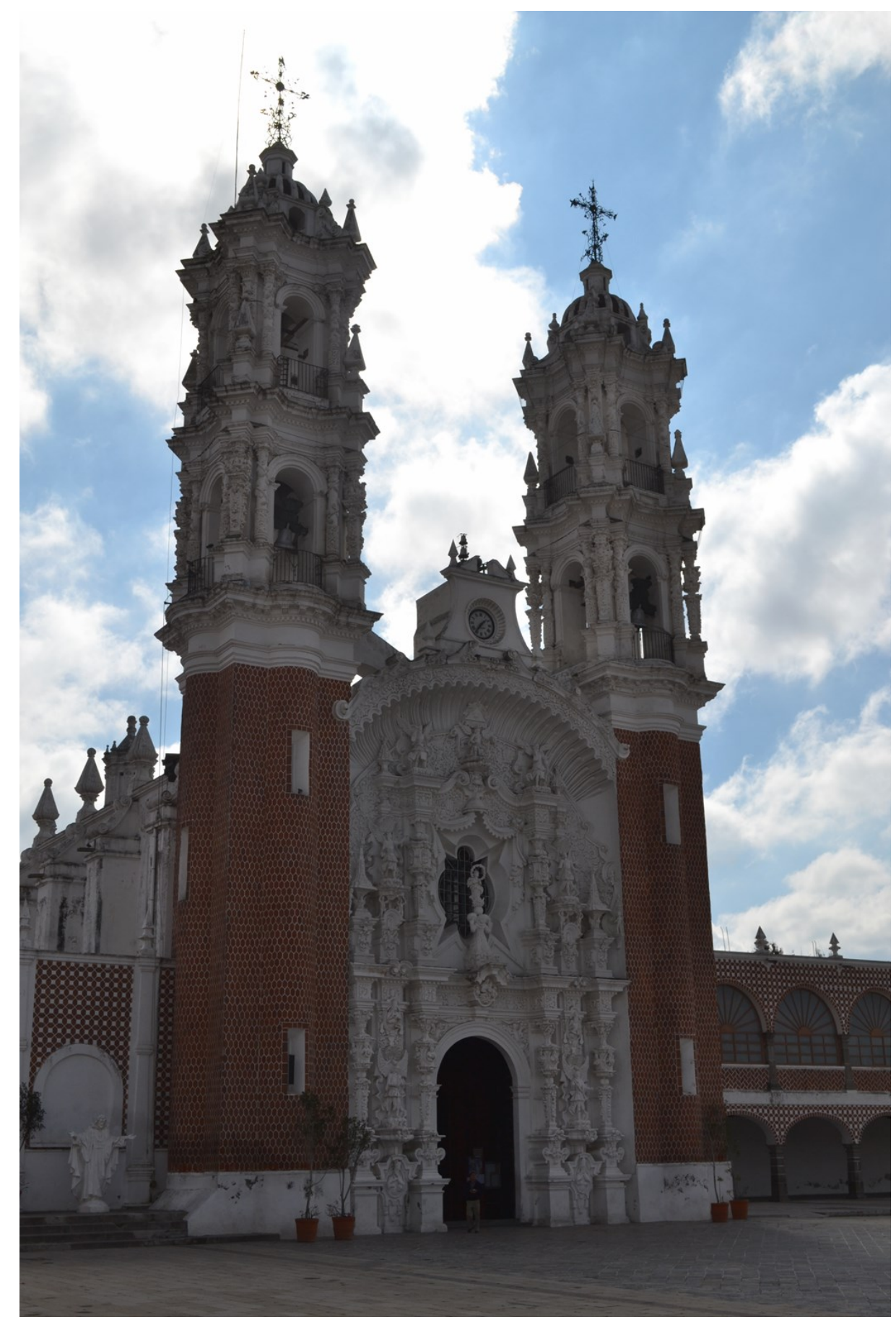

[Fig. 2.18 Façade of Santuario de Ocotlán, Tlaxcala] 


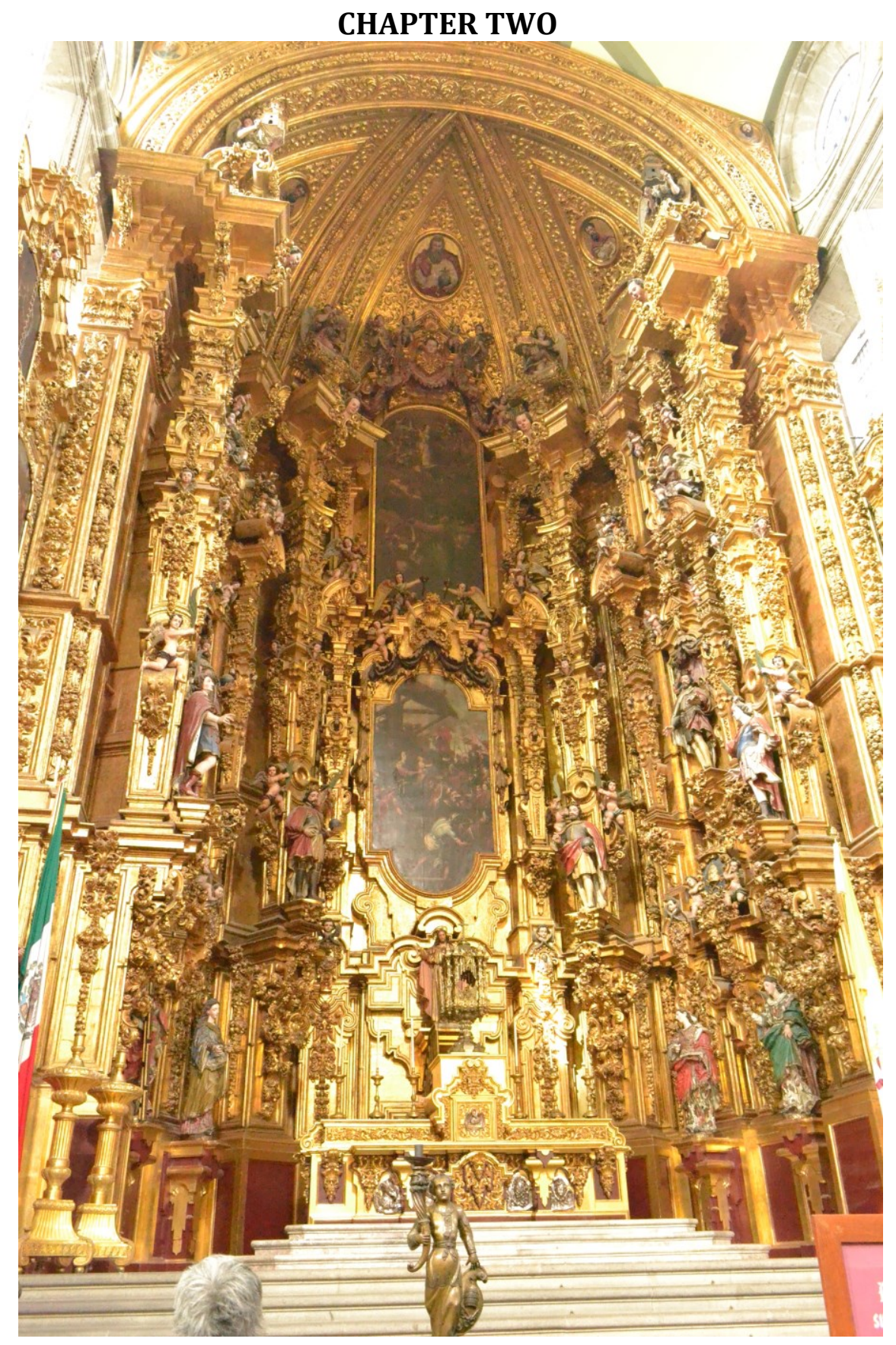

[Fig. 3.1 Jerónimo de Balbás, Retablo de los Reyes, 18th Century] 


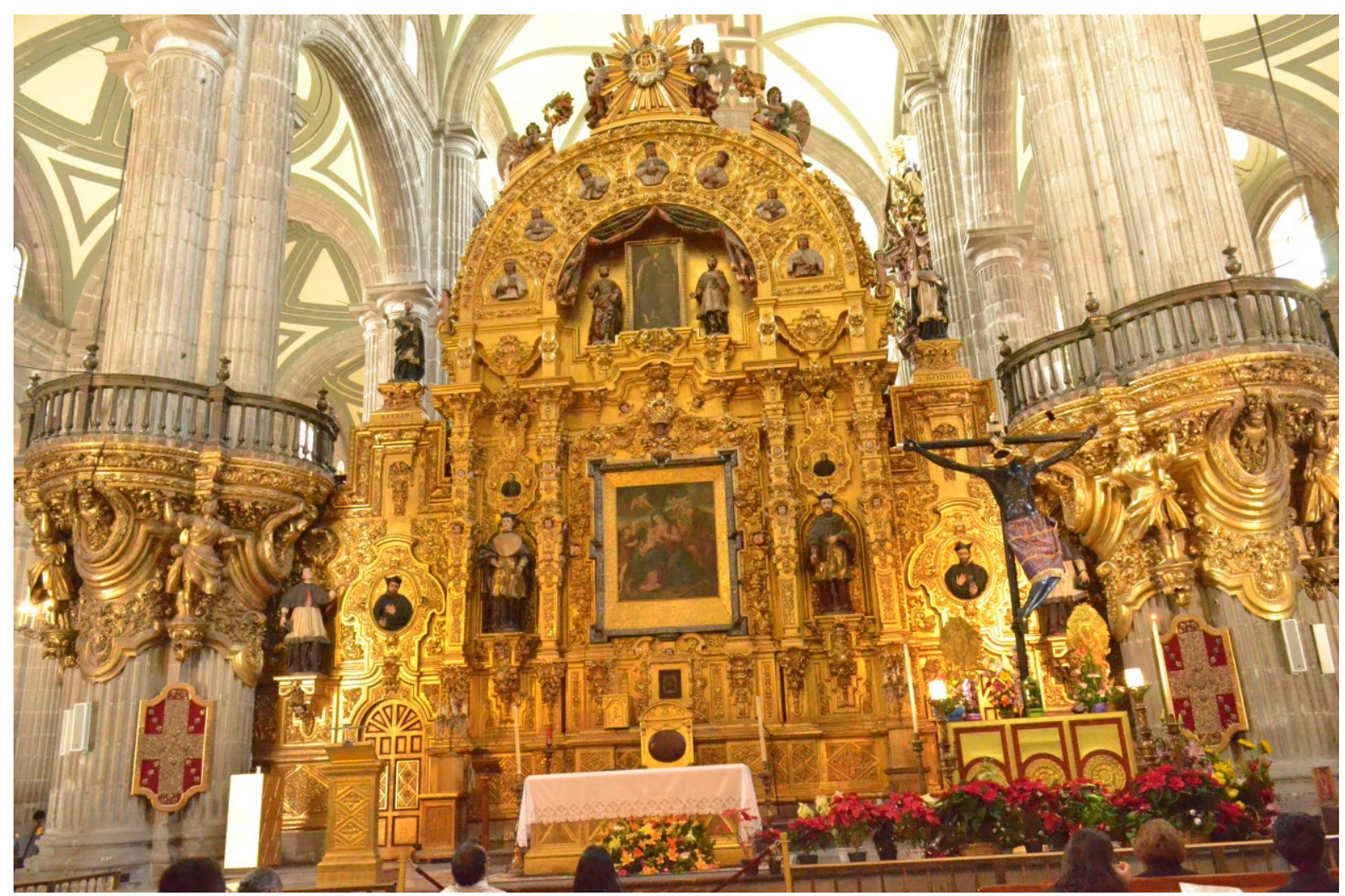

[Fig. 3.2 Jerónimo de Balbás, Retablo del Perdón, 18th Century] 


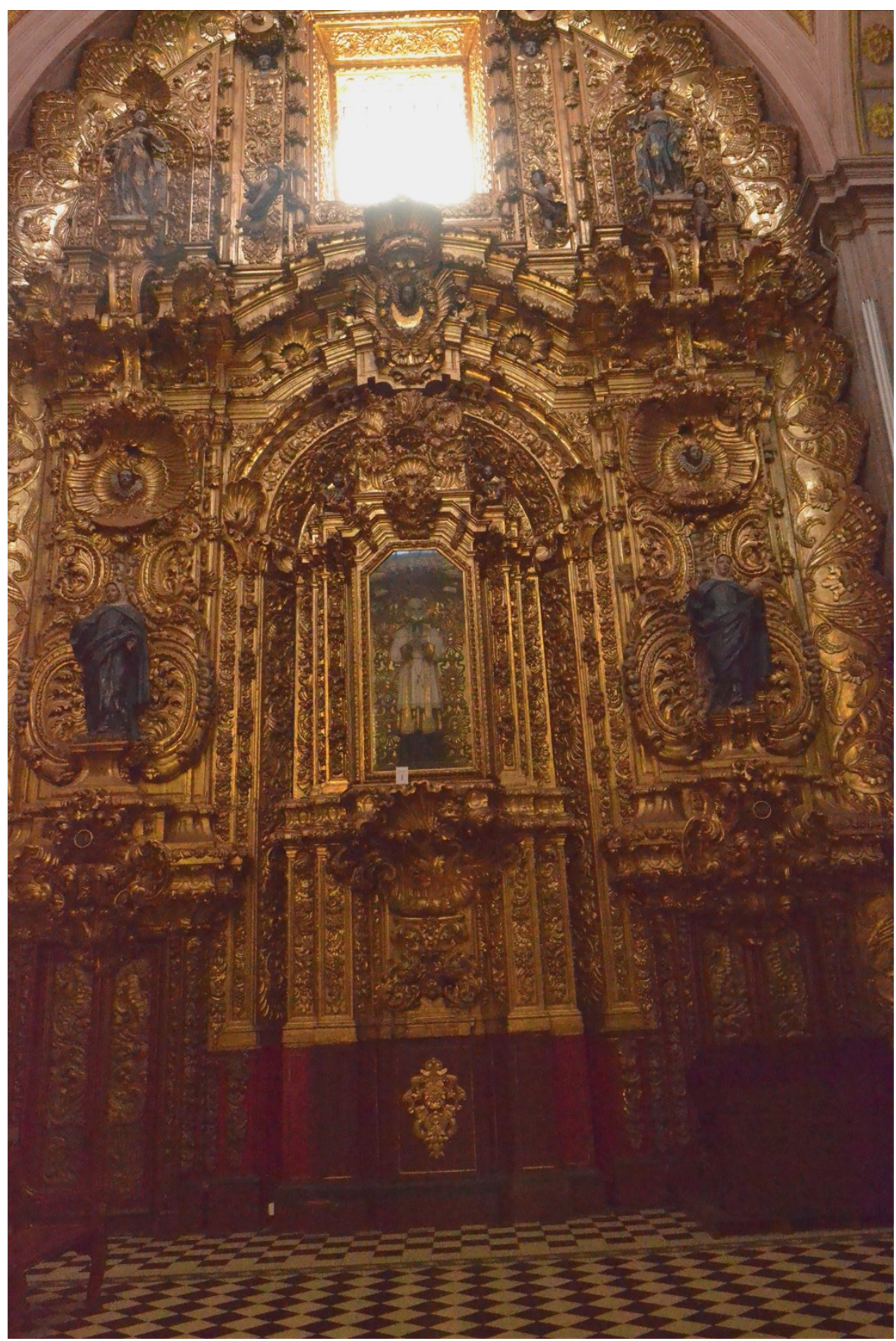

[Fig. 3.3 Interior of the Church of Santa Clara, Querétaro, Mexico] 


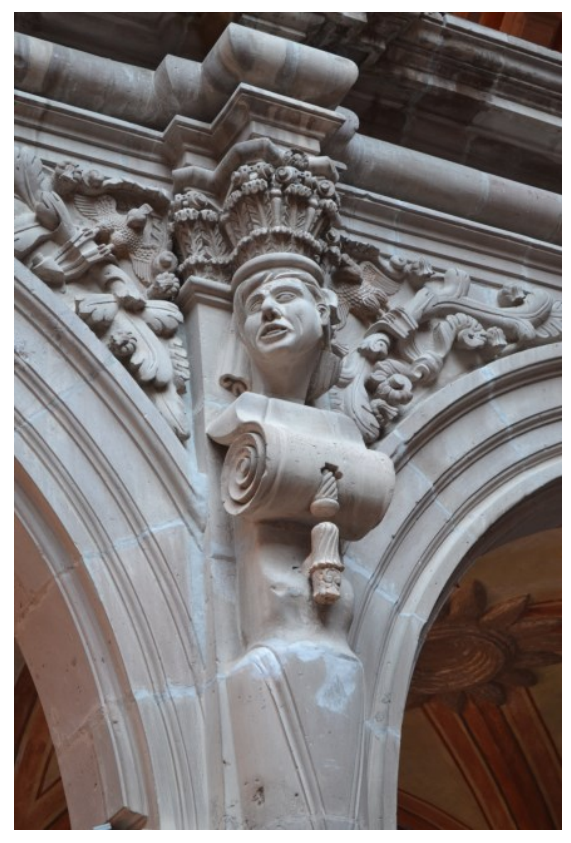

[Fig. 3.4 Detail of the Courtyard at Convent of San Agustín, Querétaro, Mexico]

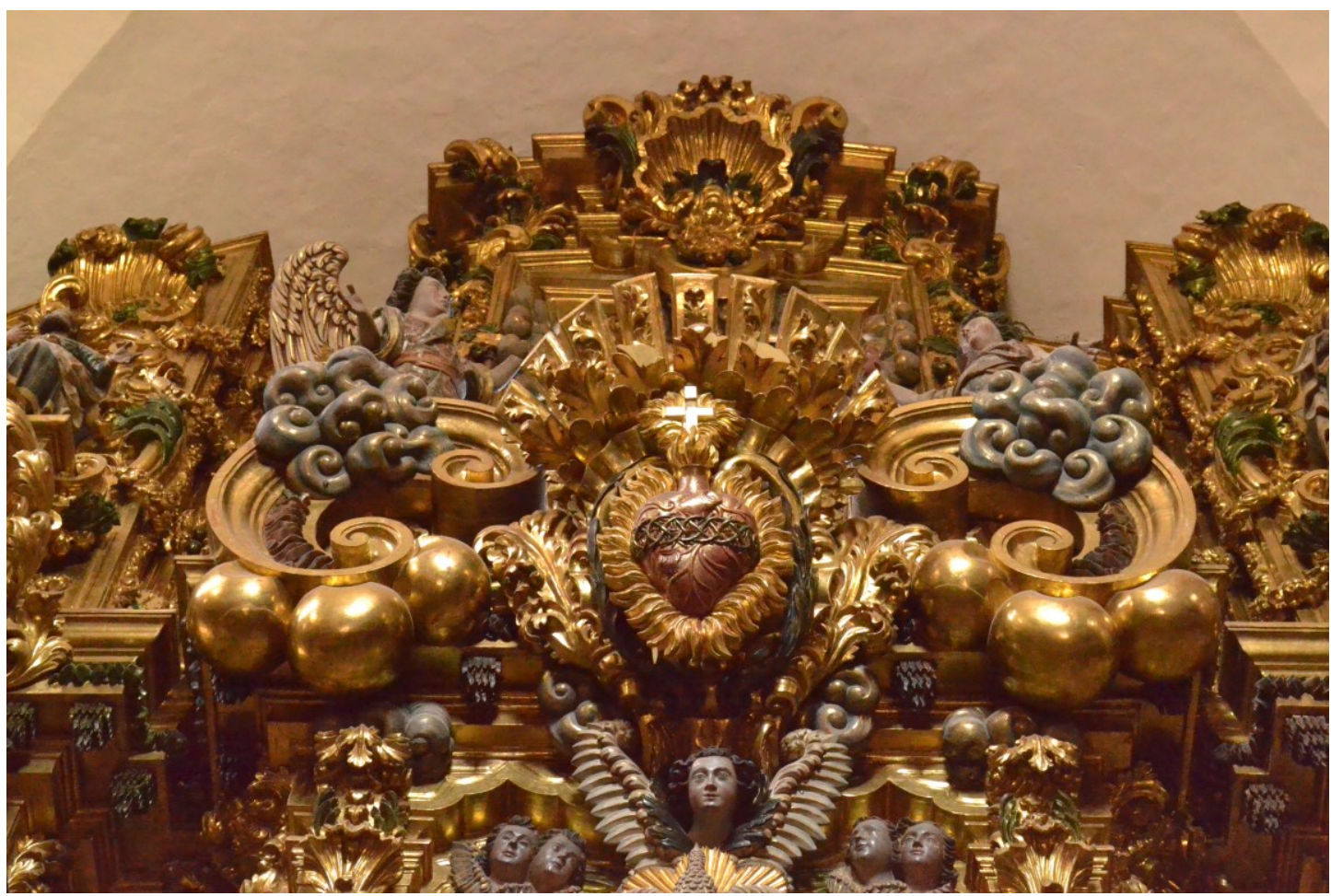

[Fig. 3.5 Detail of a retablo inside the Church of Santa Clara, Querétaro, Mexico] 


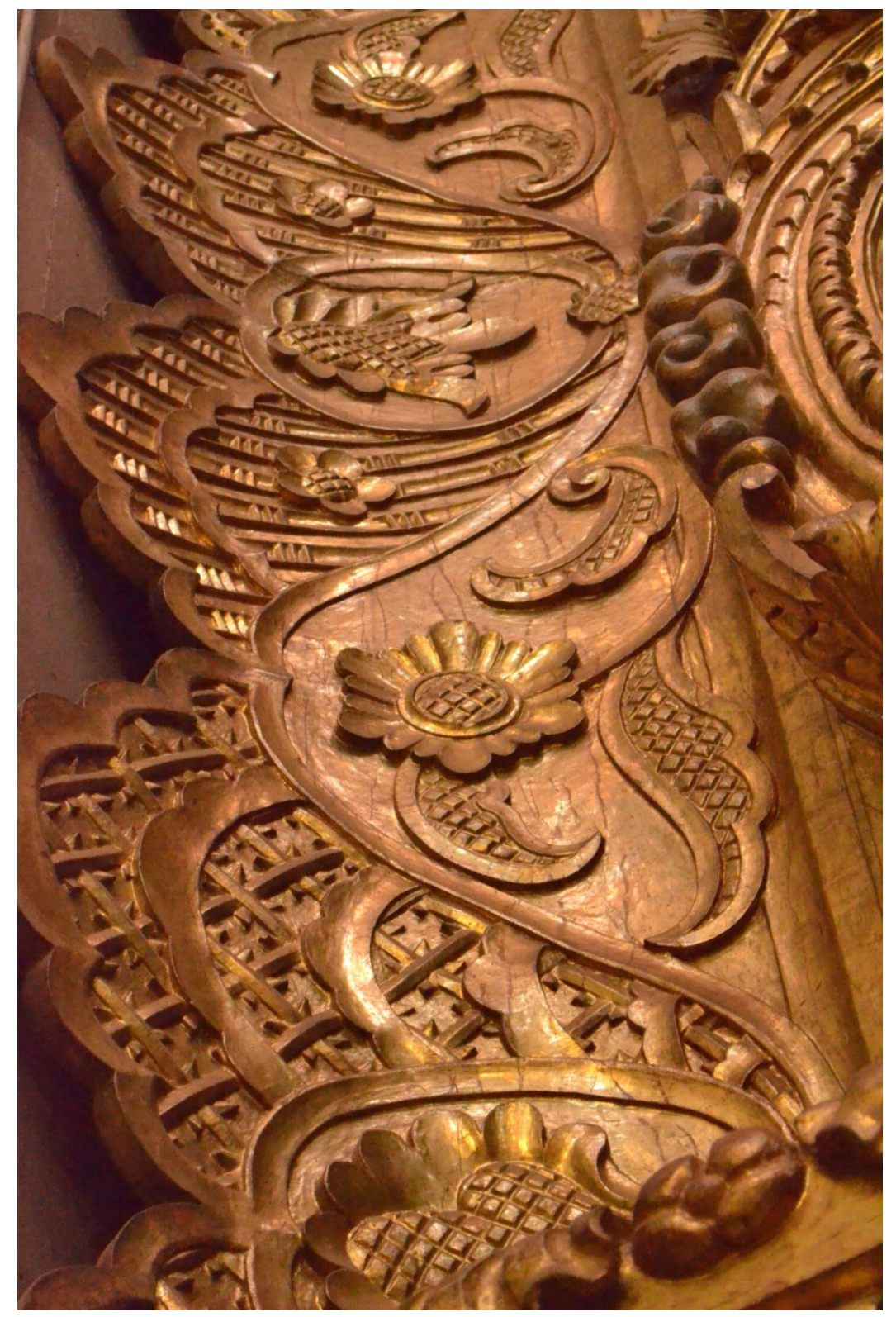

[Fig. 3.6 Detail of a retablo inside the Church of Santa Clara, Querétaro, Mexico] 


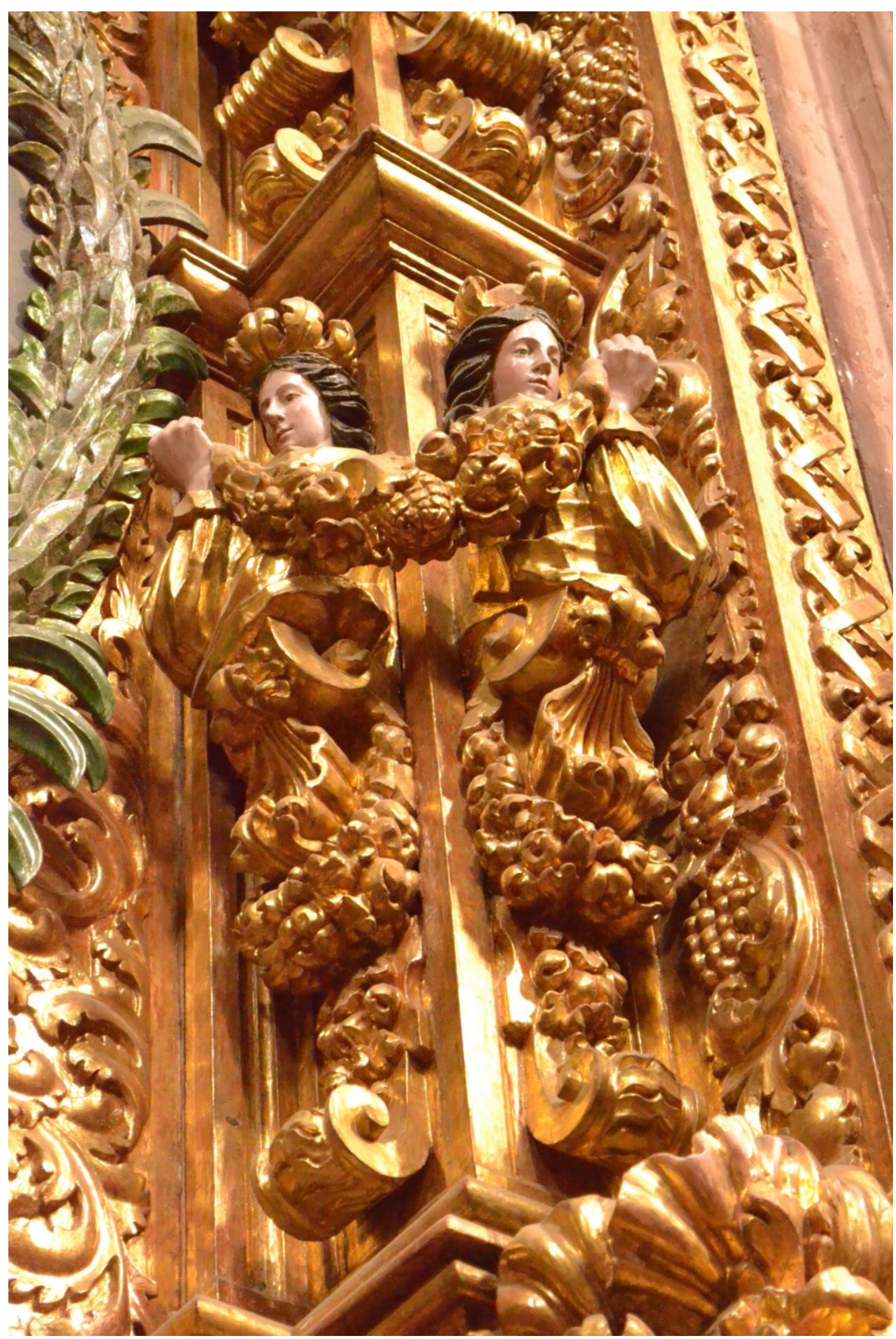

[Fig. 3.7 Detail of a retablo inside the Church of Santa Rosa, Querétaro, Mexico] 


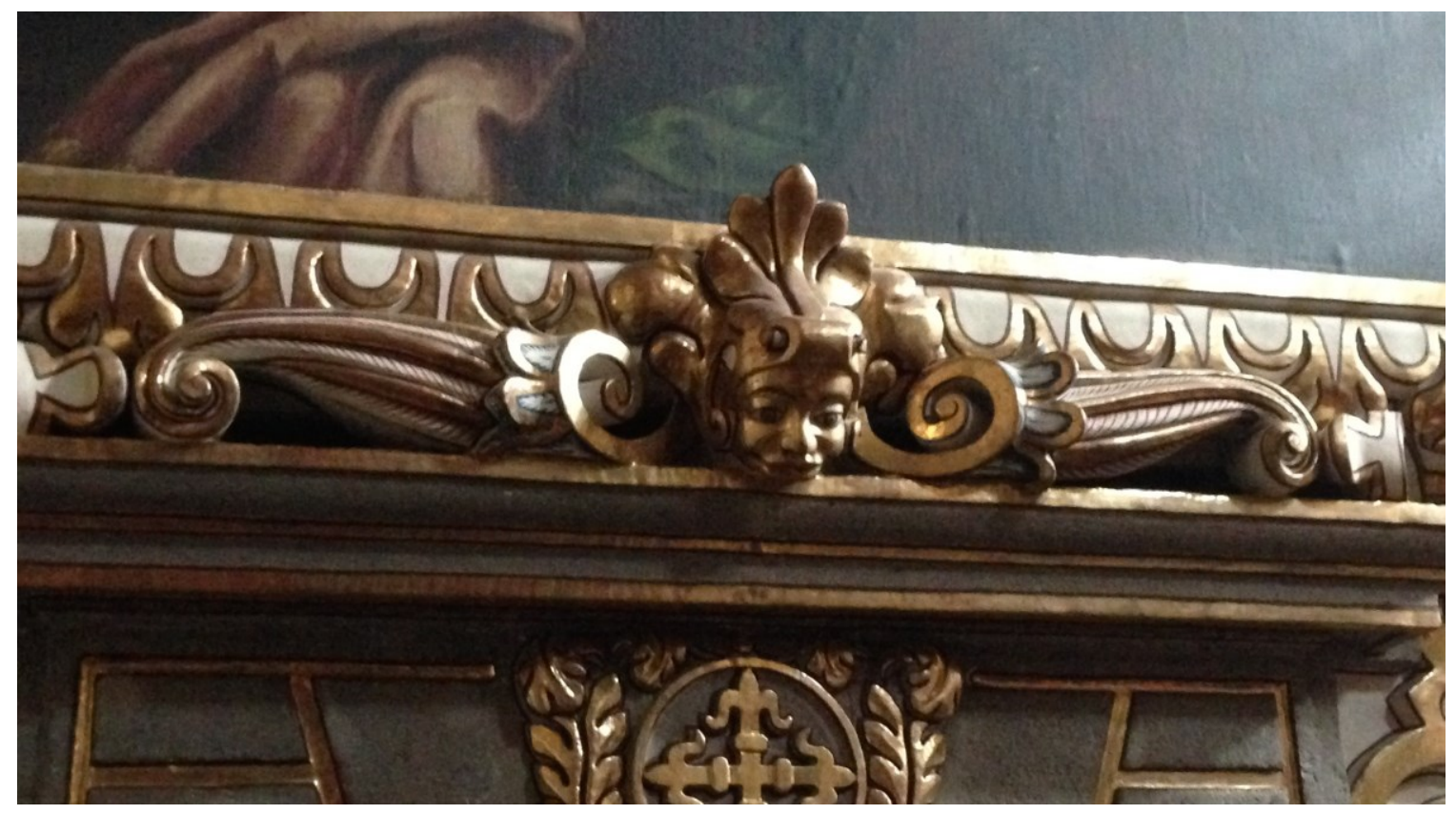

[Fig. 3.8 Detail of the inside of Capilla del Rosario, Puebla, Mexico]

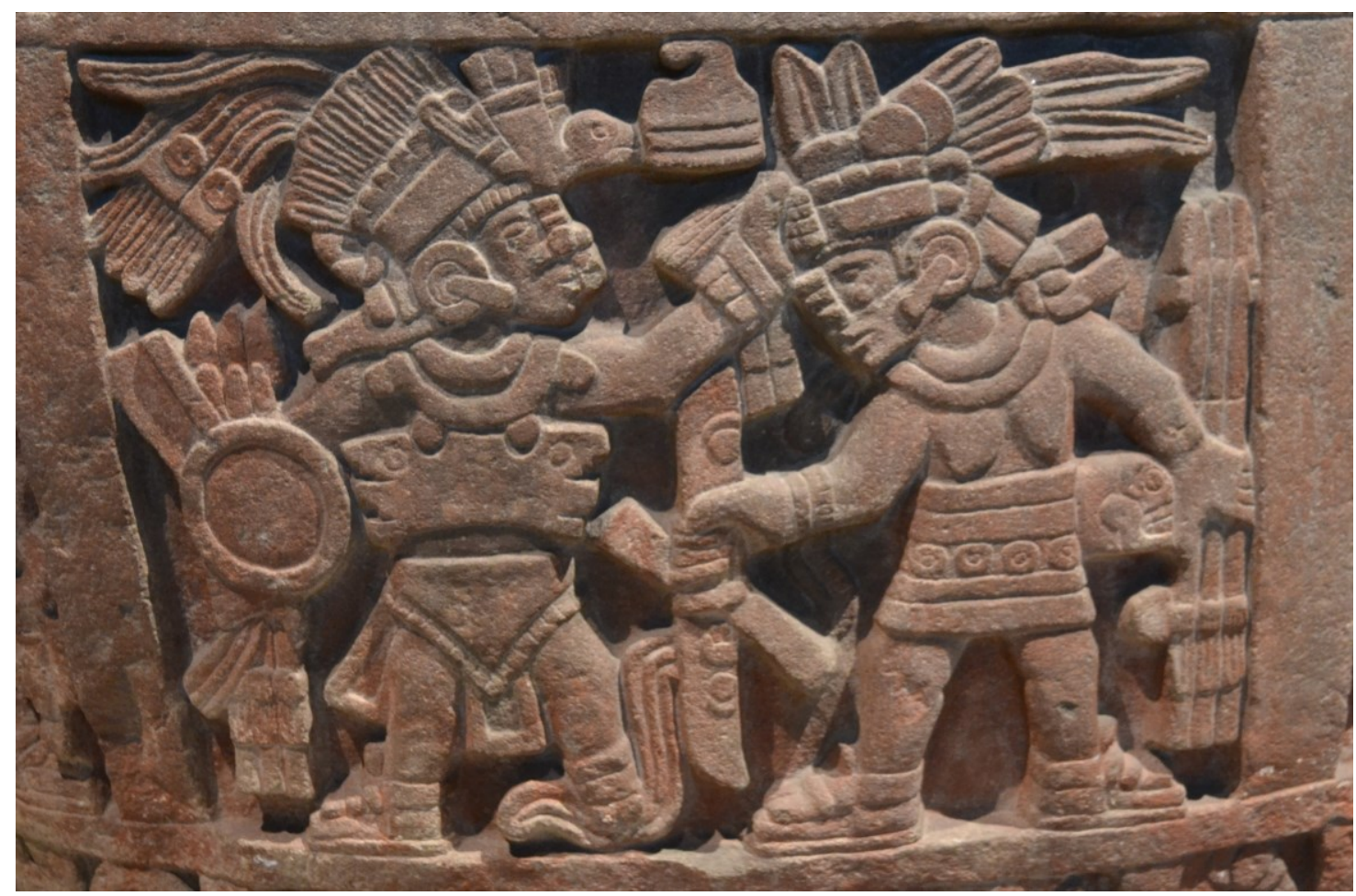

[Fig. 3.9 Detail of the Stone of Moctezuma I in the National Anthropology Museum of Mexico City] 


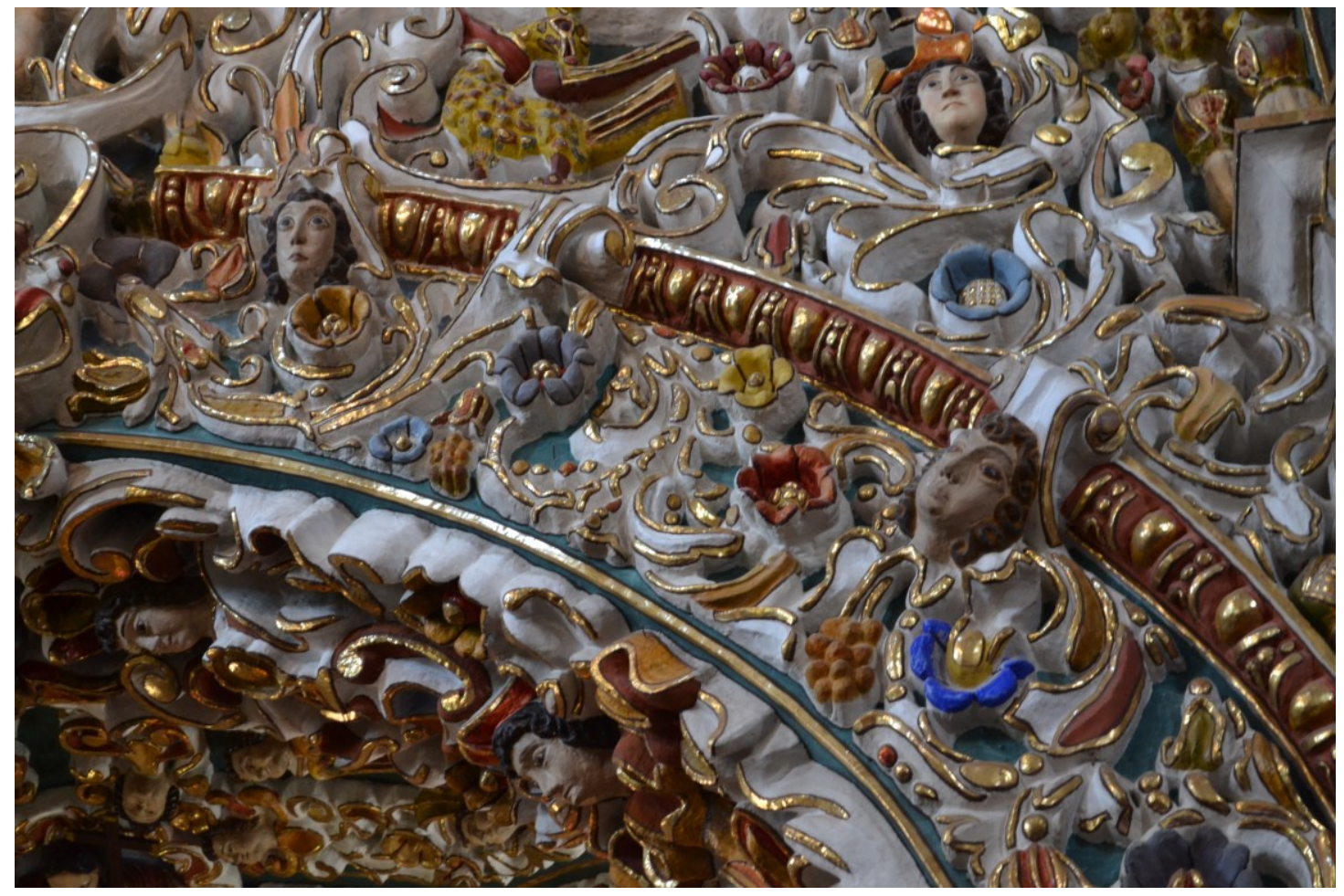

[Fig. 3.10 Detail of the inside of Santa María Tonantzintla, Puebla, Mexico] 


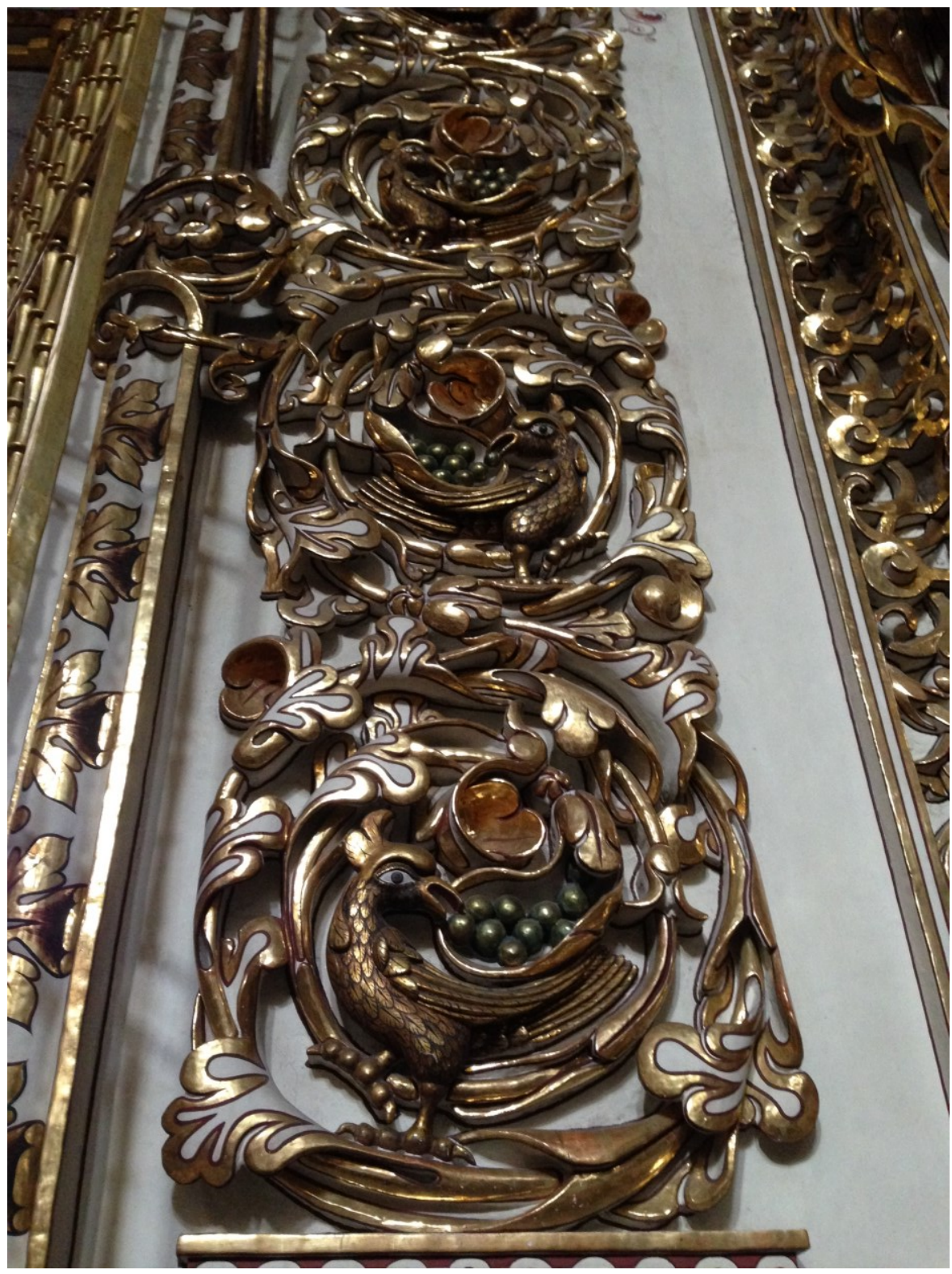


[Fig. 3.11 Detail of the inside of Capilla del Rosario, Puebla, Mexico]

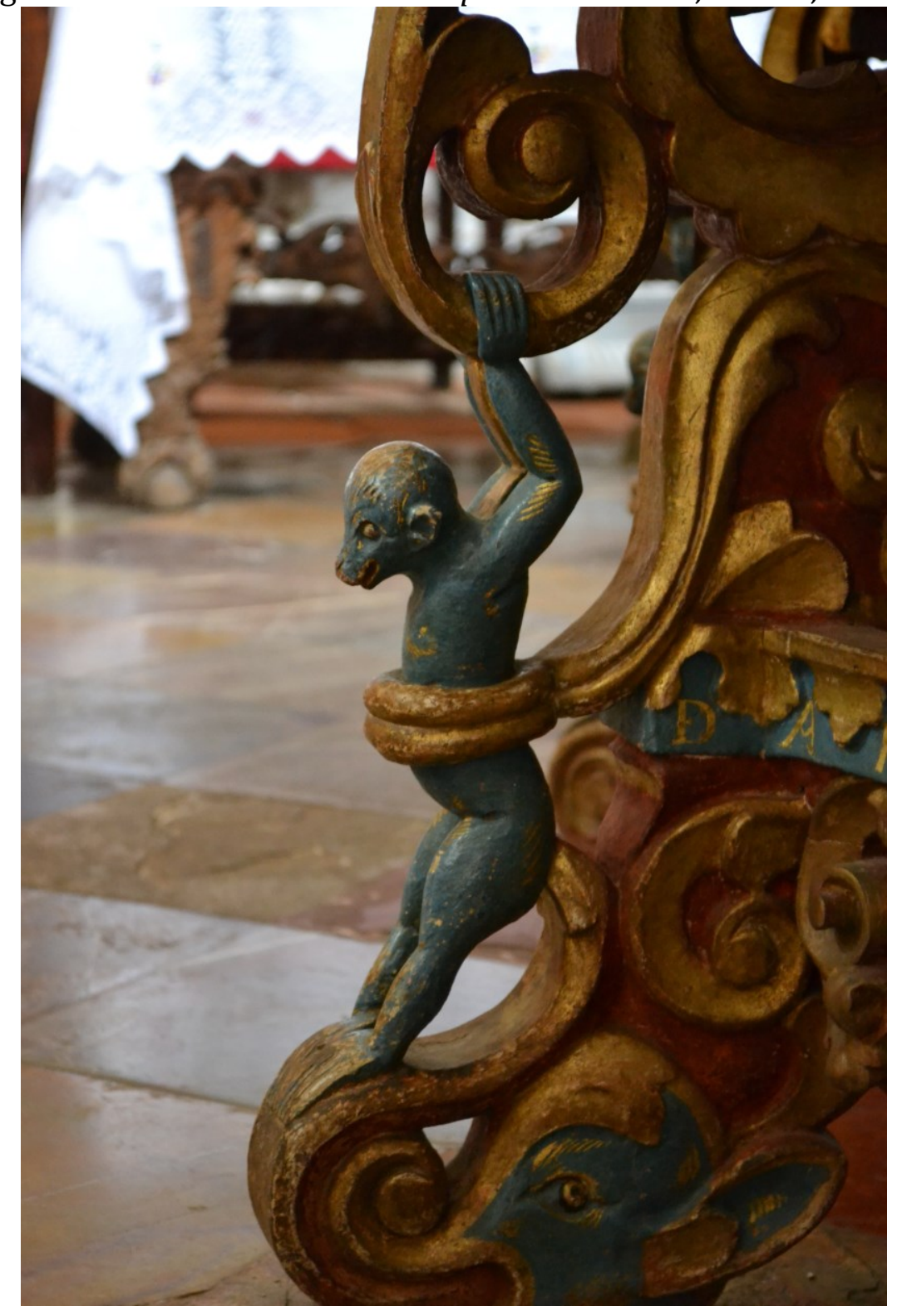

[Fig. 3.12 Detail of table inside the Camarín at Santuario de Ocotlán, Tlaxcala, Mexico] 


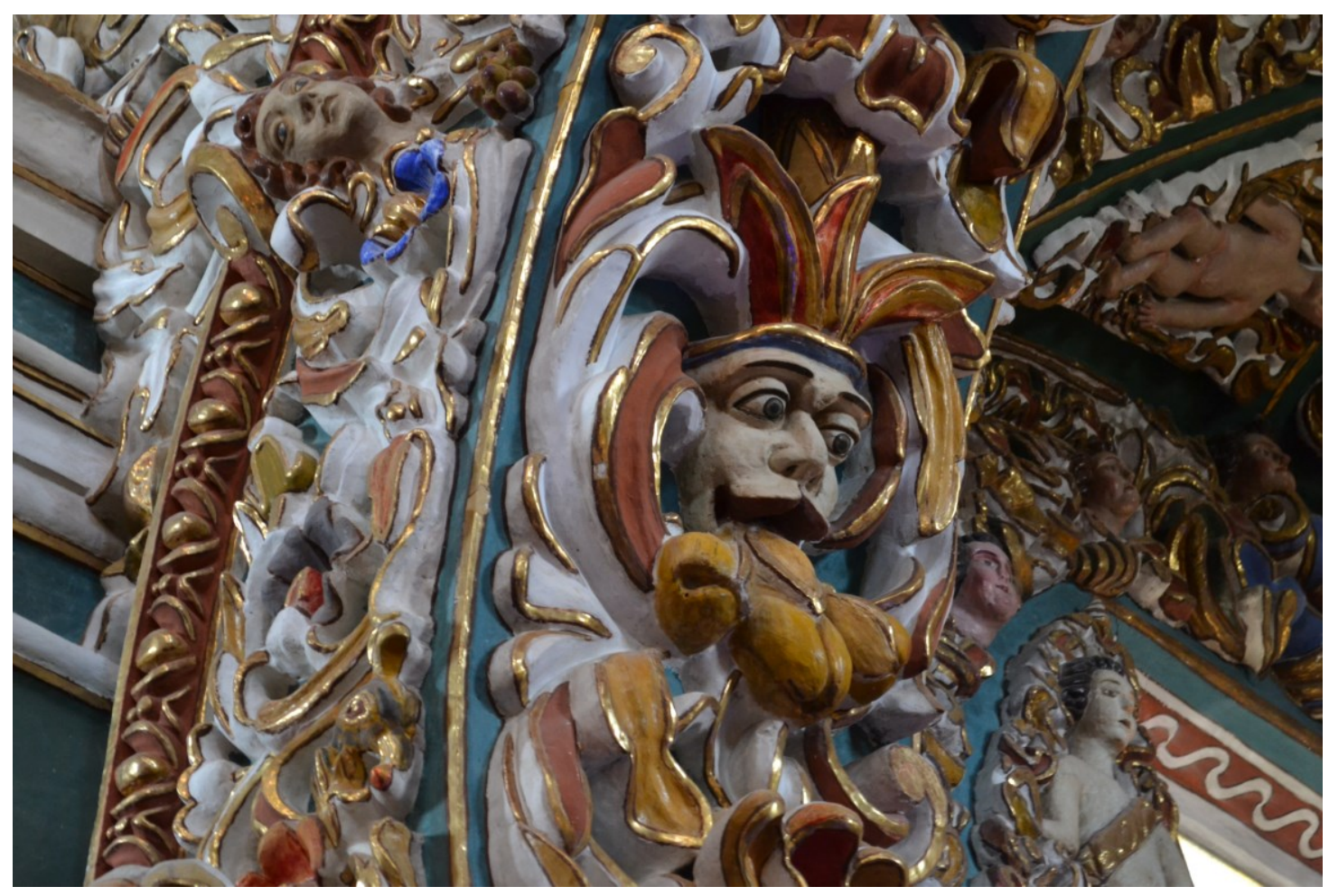

[Fig. 3.13 Detail of the inside of Santa María Tonantzintla, Puebla, Mexico] 


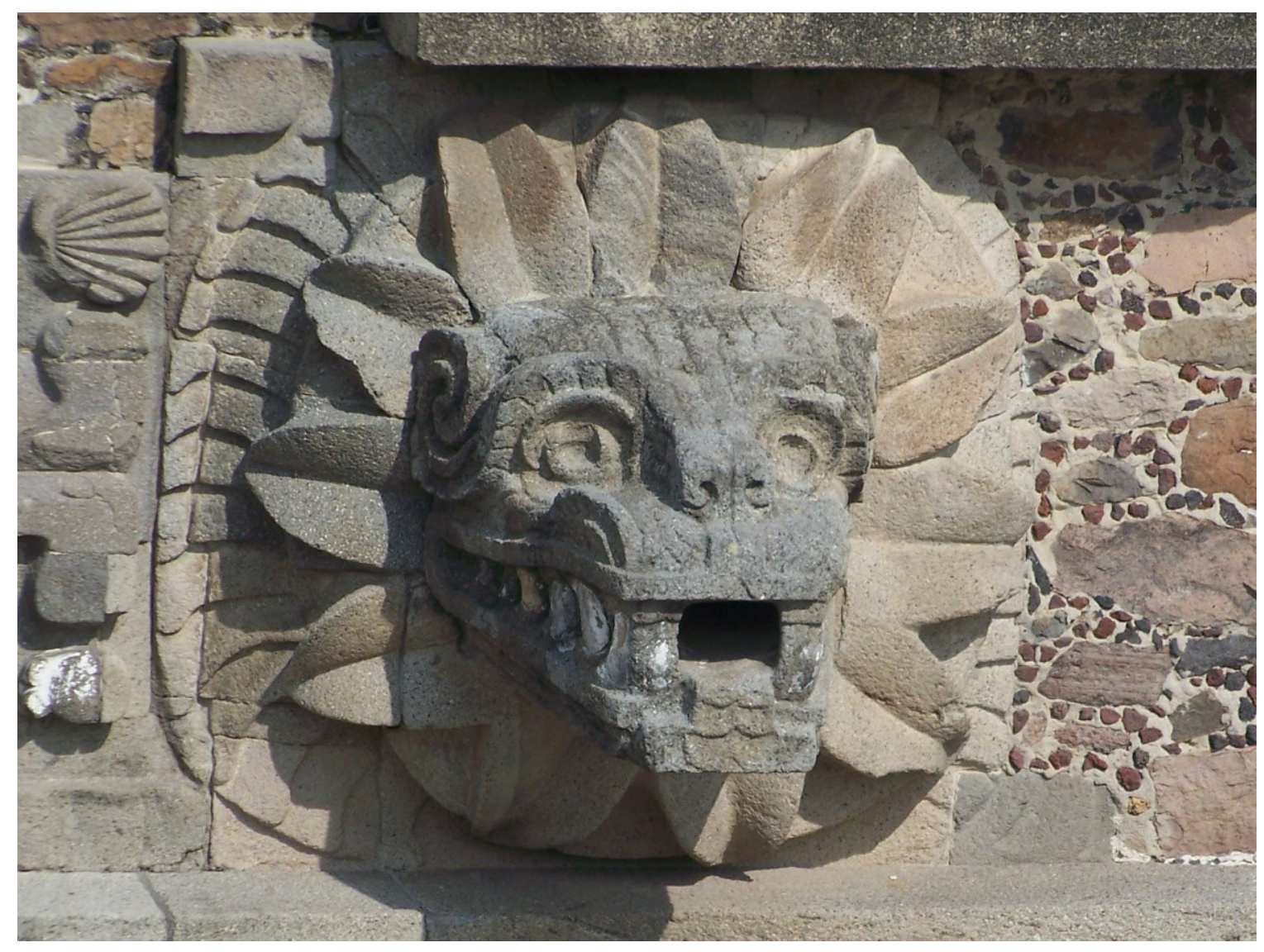

[Fig. 3.14 Stone sculpture from the Archeological Site of Teotihuacán, Mexico]

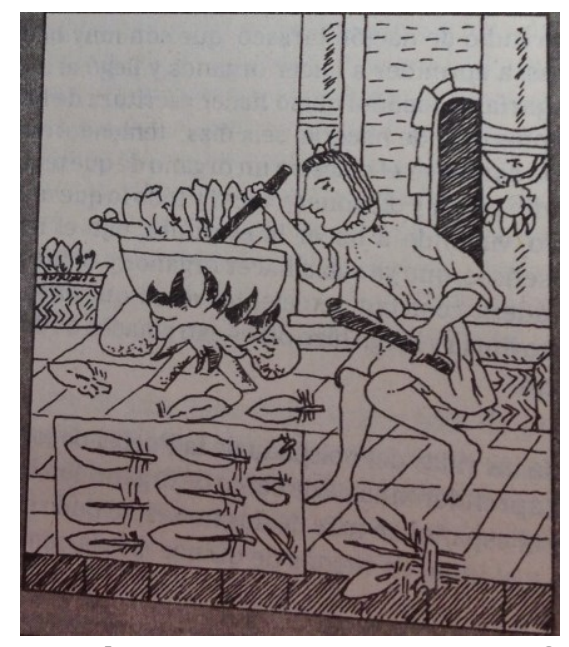

[Fig. 3.15 Image of an Indigenous man preparing feathers to decorate] 


\section{CHAPTER THREE}

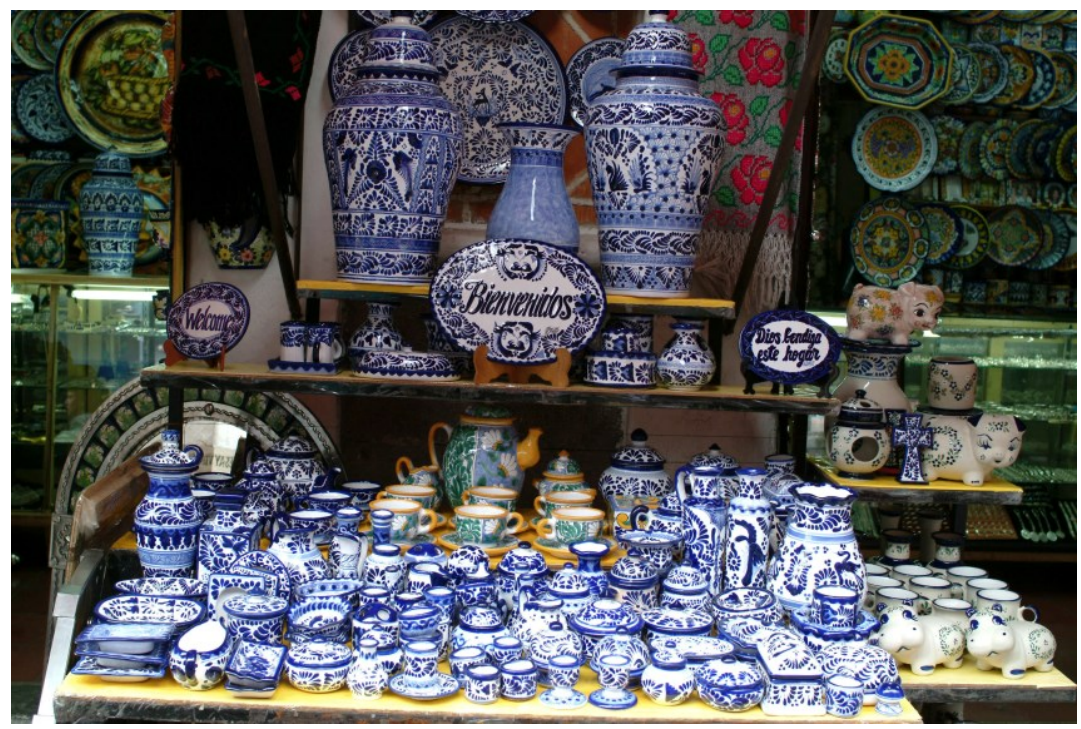

[Fig. 4.1 Pueblan Ceramic]

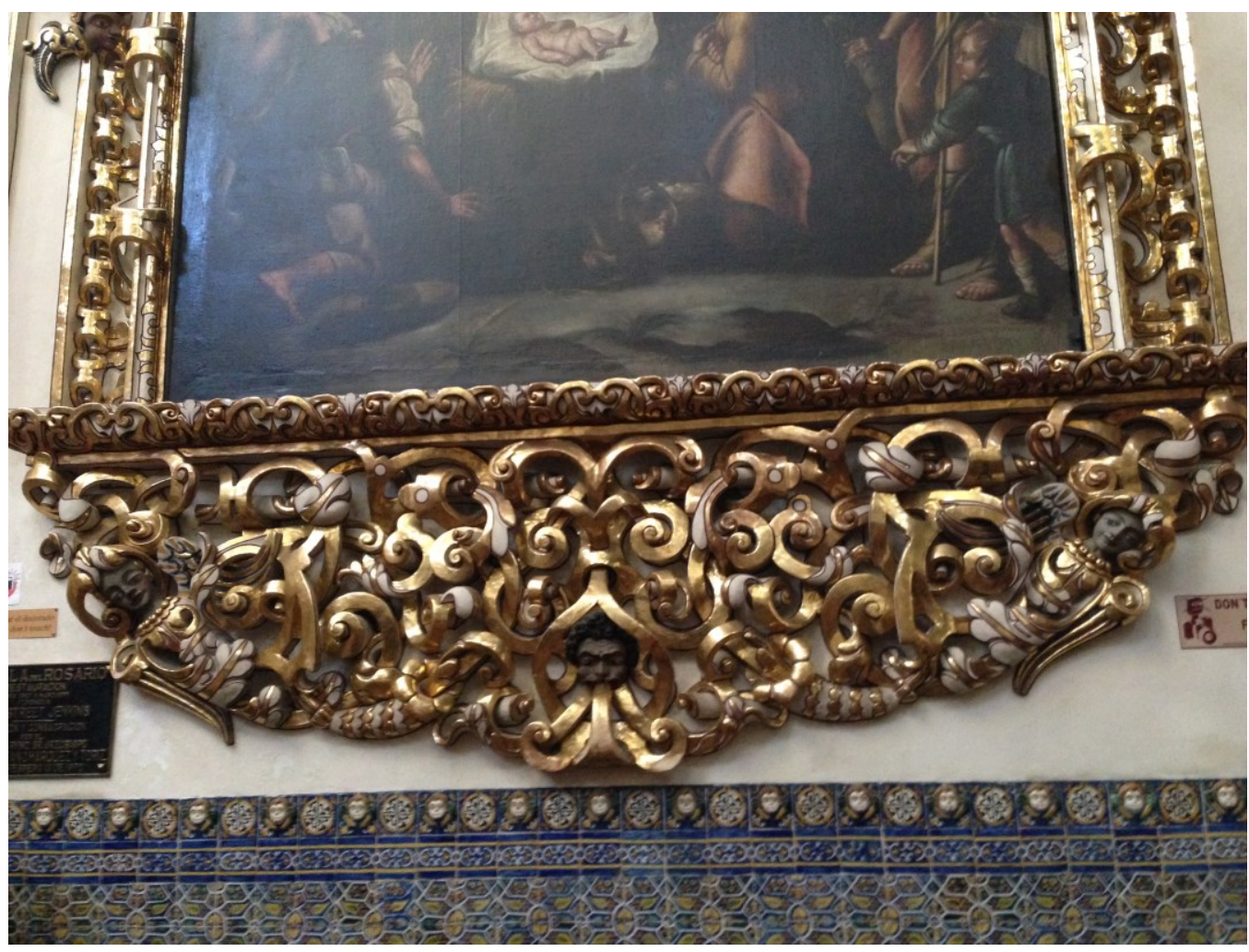

[Fig. 4.2 Detail of the inside of Capilla del Rosario, Puebla, Mexico] 


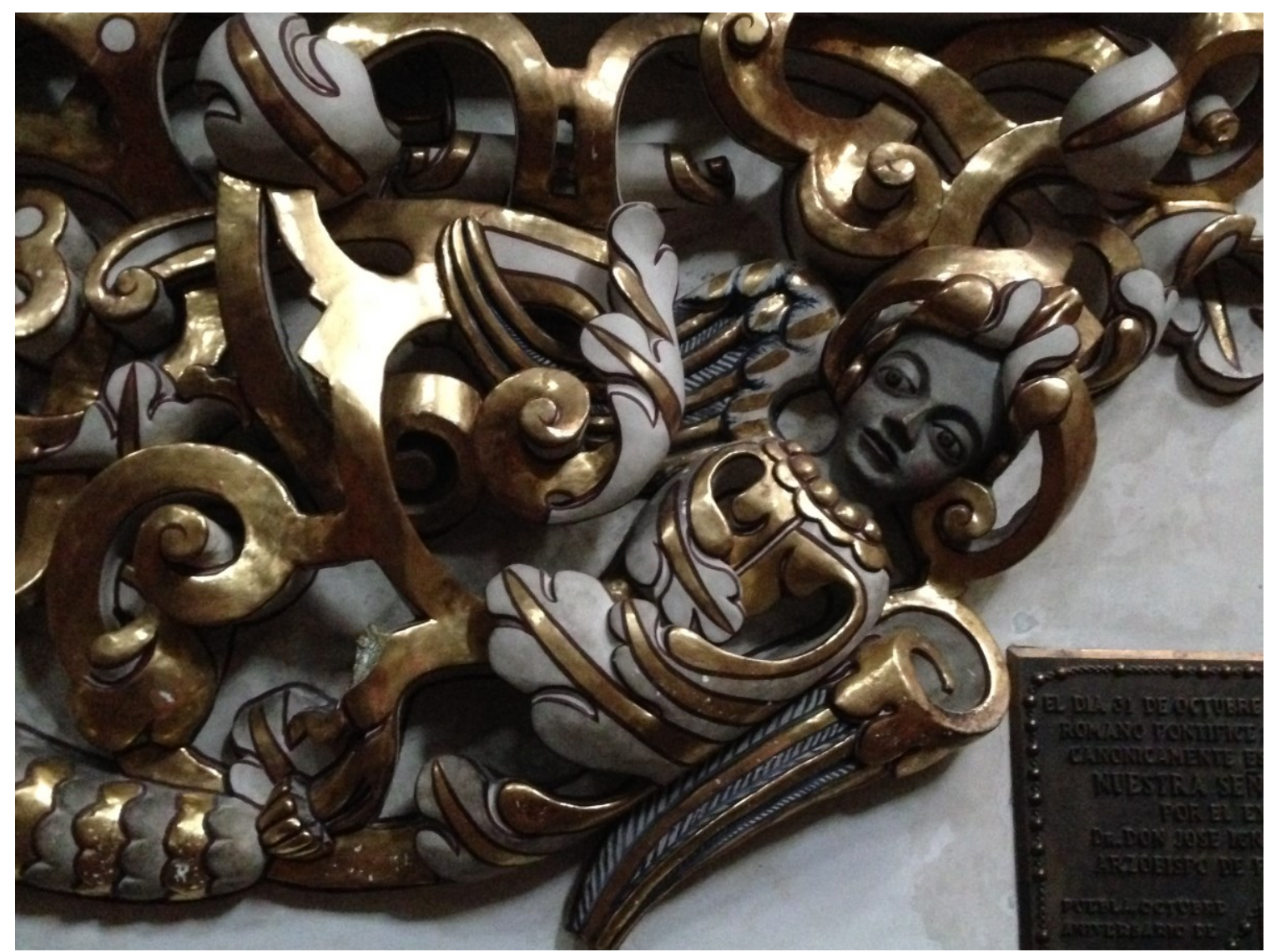

[Fig. 4.3 Detail of the inside of Capilla del Rosario, Puebla, Mexico] 


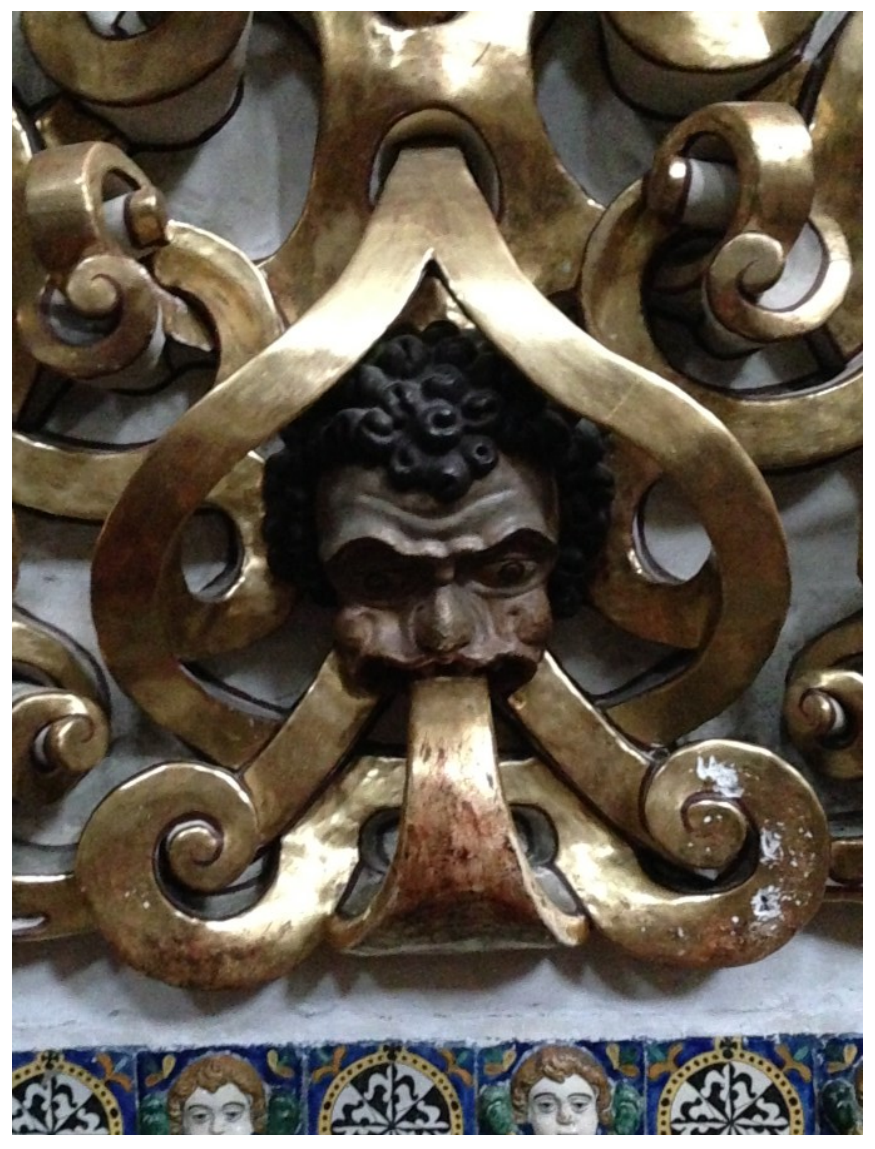

[Fig. 4.4 Detail of the inside of Capilla del Rosario, Puebla, Mexico] 


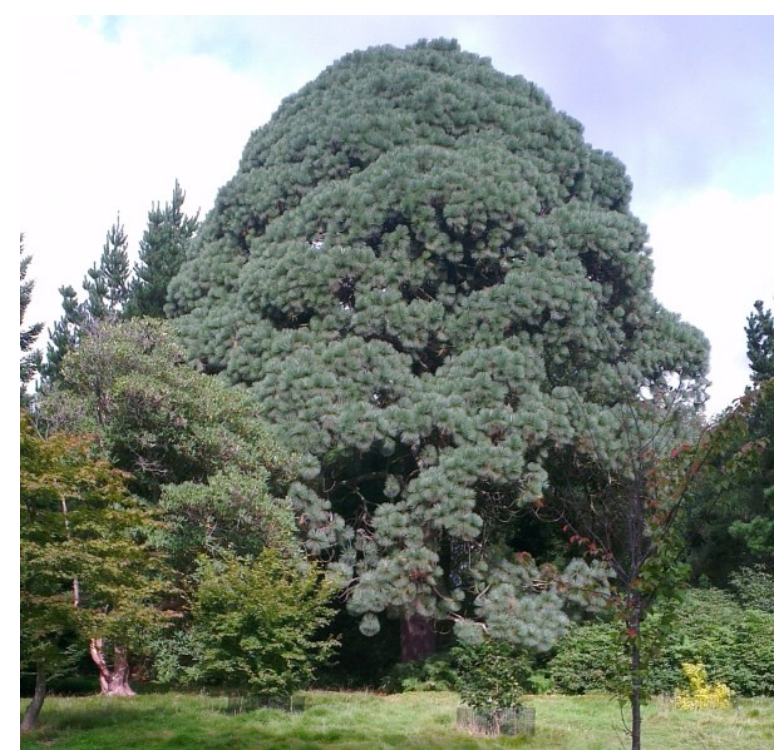

[Fig. 4.5 Ocote tree]

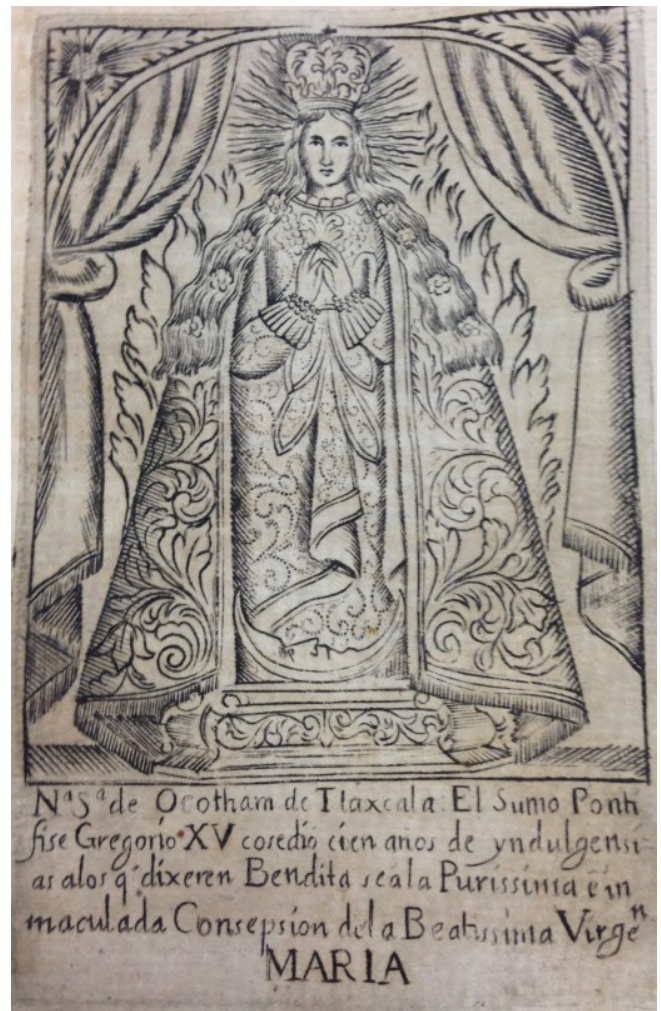

[Fig. 4.6 Image of the Virgin of Ocotlán] 


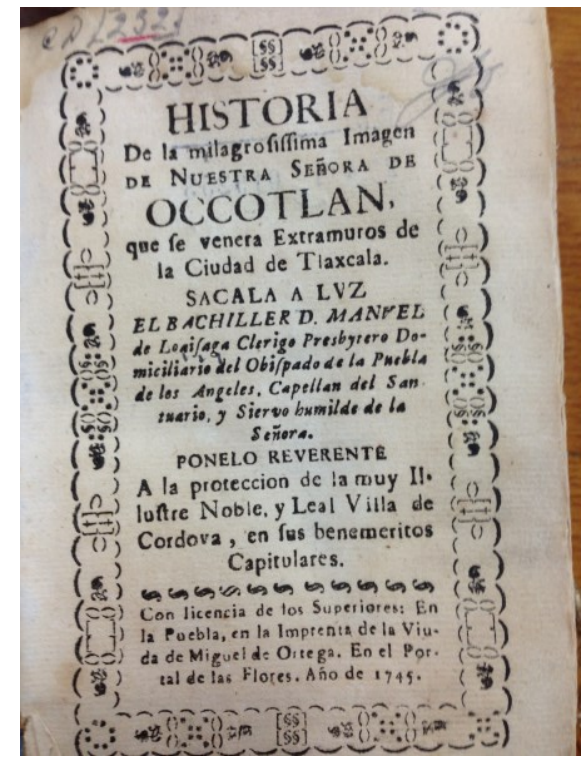

[Fig. 4.7 Title page of Manuel de Loayzaga's book] 


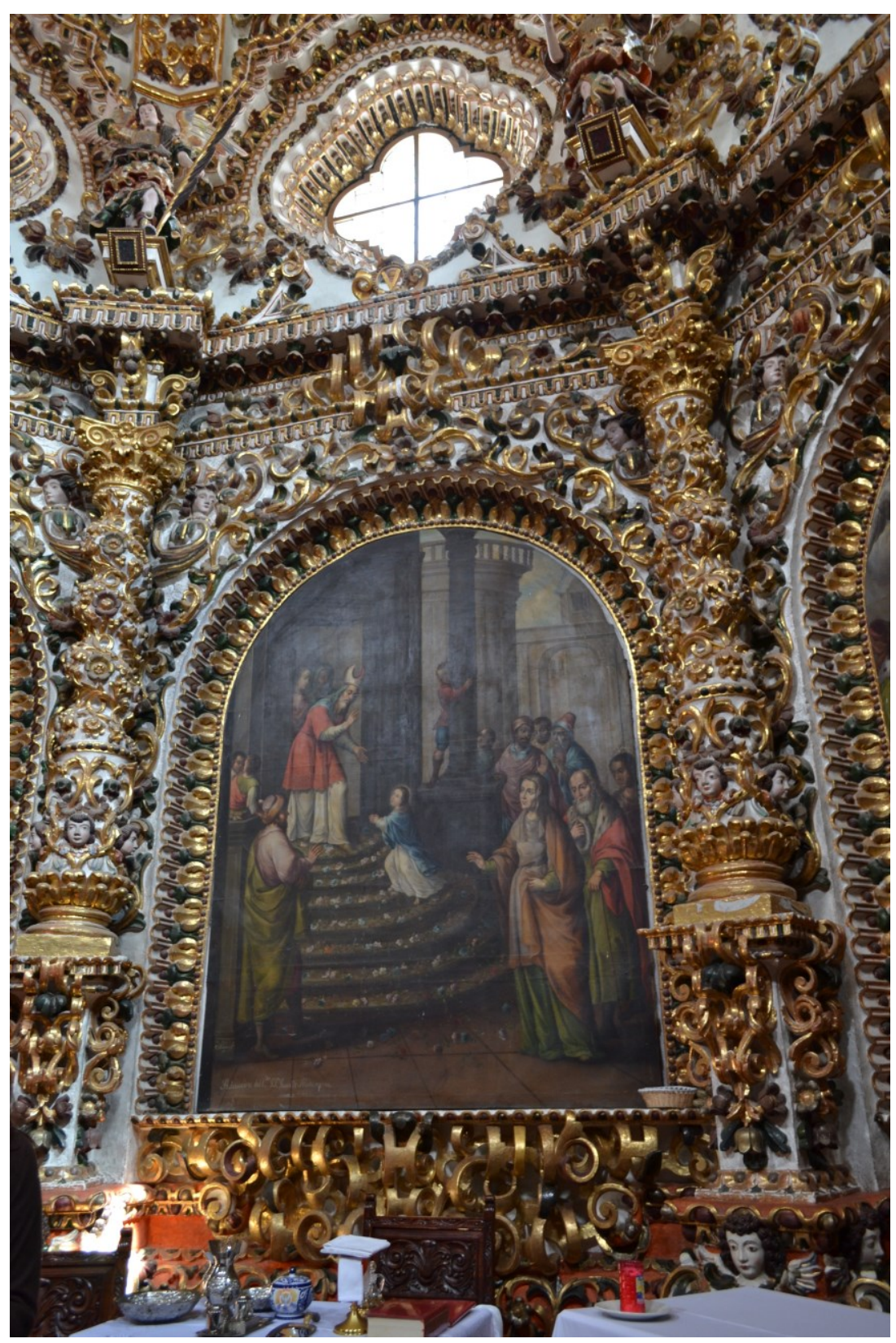

[Fig. 4.8 Francisco Miguel Tlayoltehuanitzi, Detail of the Camarín inside the Santuario de Ocotlán, Tlaxcala, Mexico] 


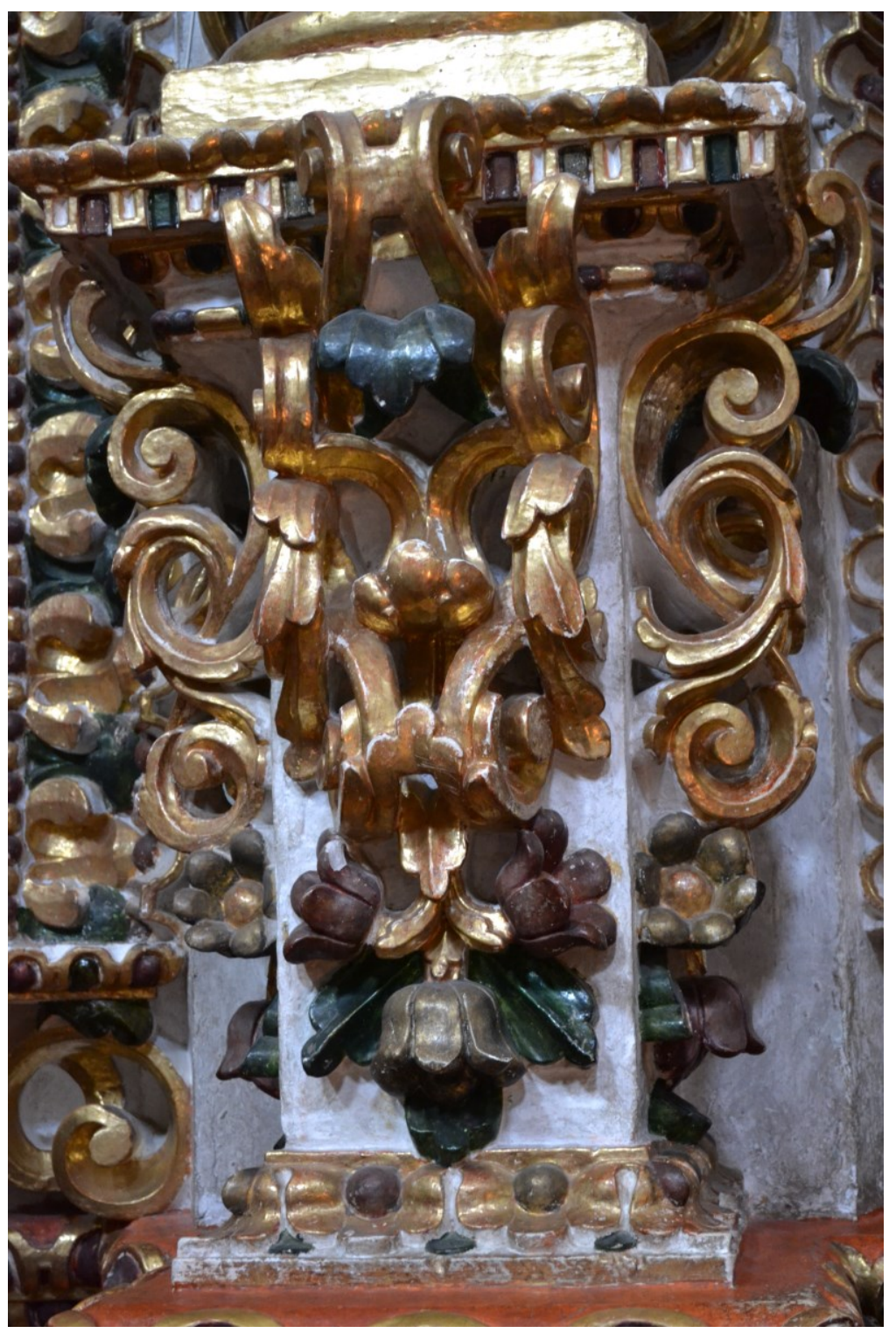

[Fig. 4.9 Francisco Miguel Tlayoltehuanitzi, Detail of the Camarín inside the Santuario de Ocotlán, Tlaxcala, Mexico] 


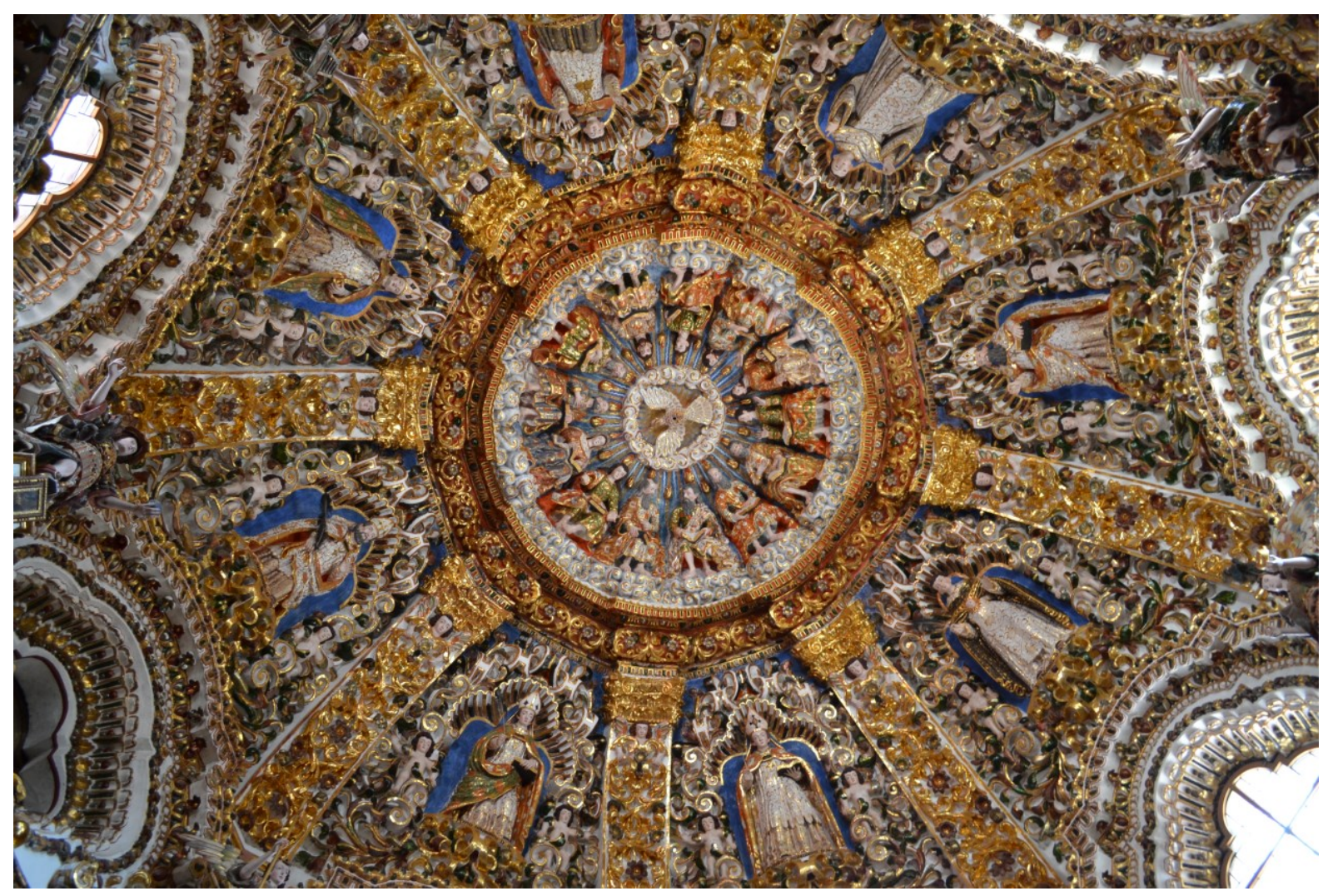

[Fig. 4.10 Francisco Miguel Tlayoltehuanitzi, Detail of the Dome in the Camarín] 


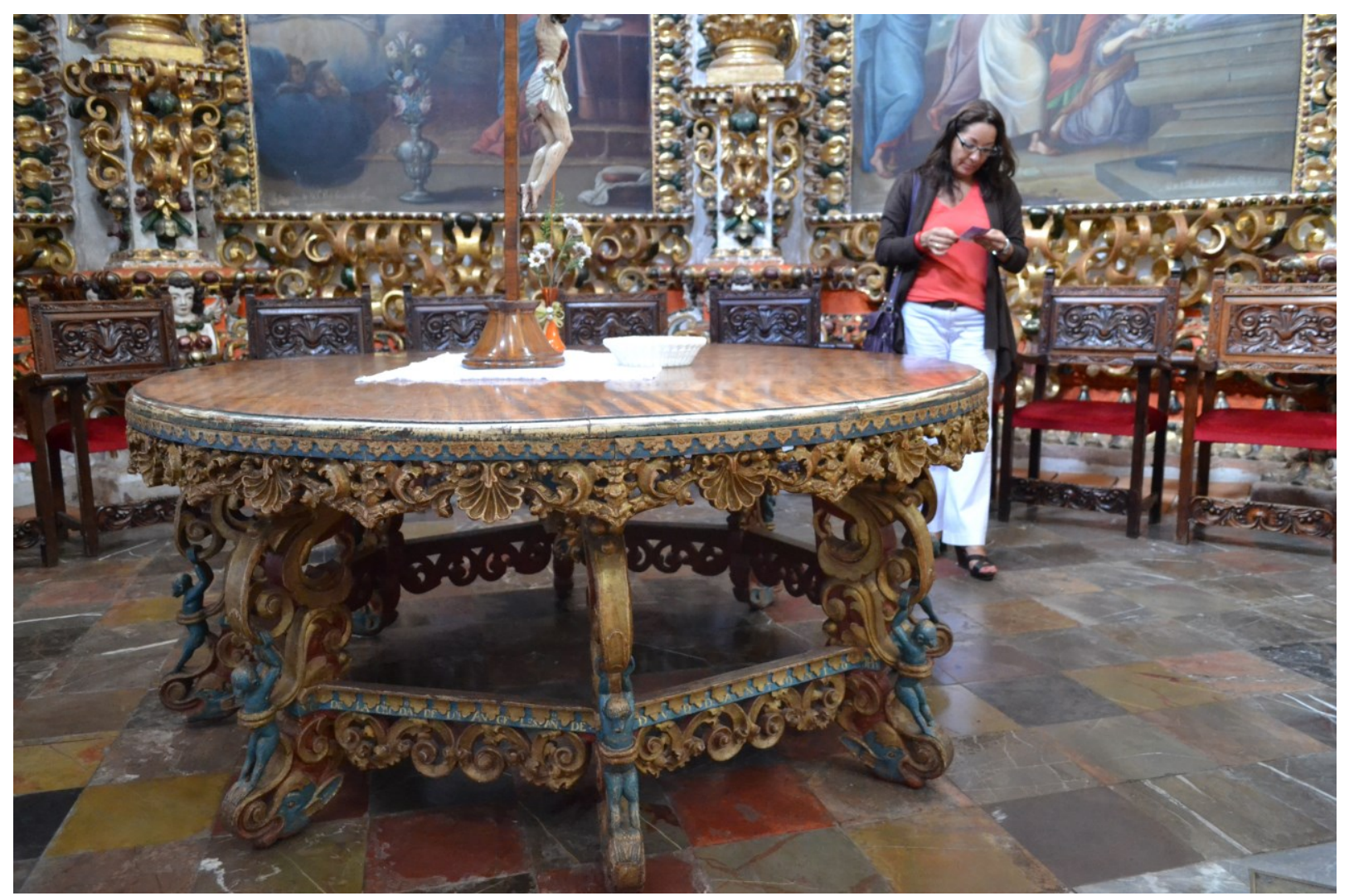

[Fig. 4.11 Francisco Miguel Tlayoltehuanitzi, Wooden table inside the Camarín] 


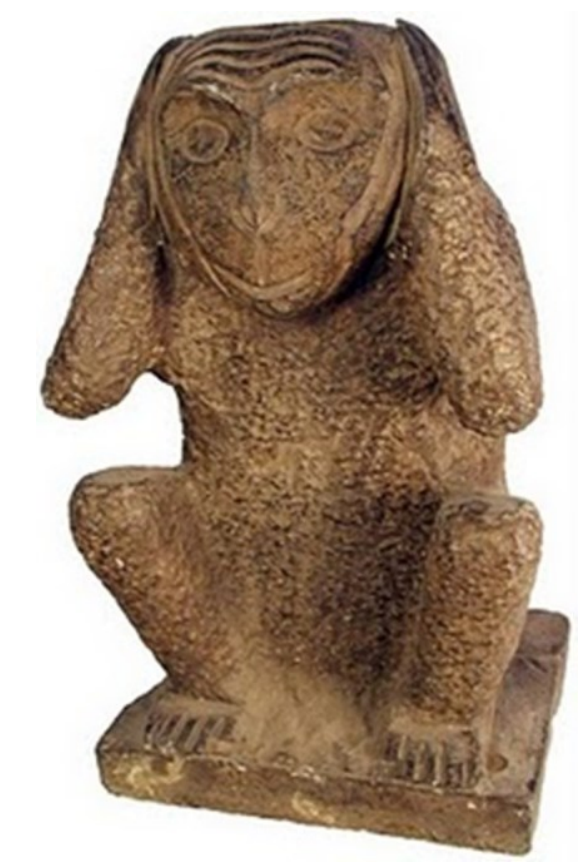

[Fig. 4.12 Aztec stone sculpture of a monkey]

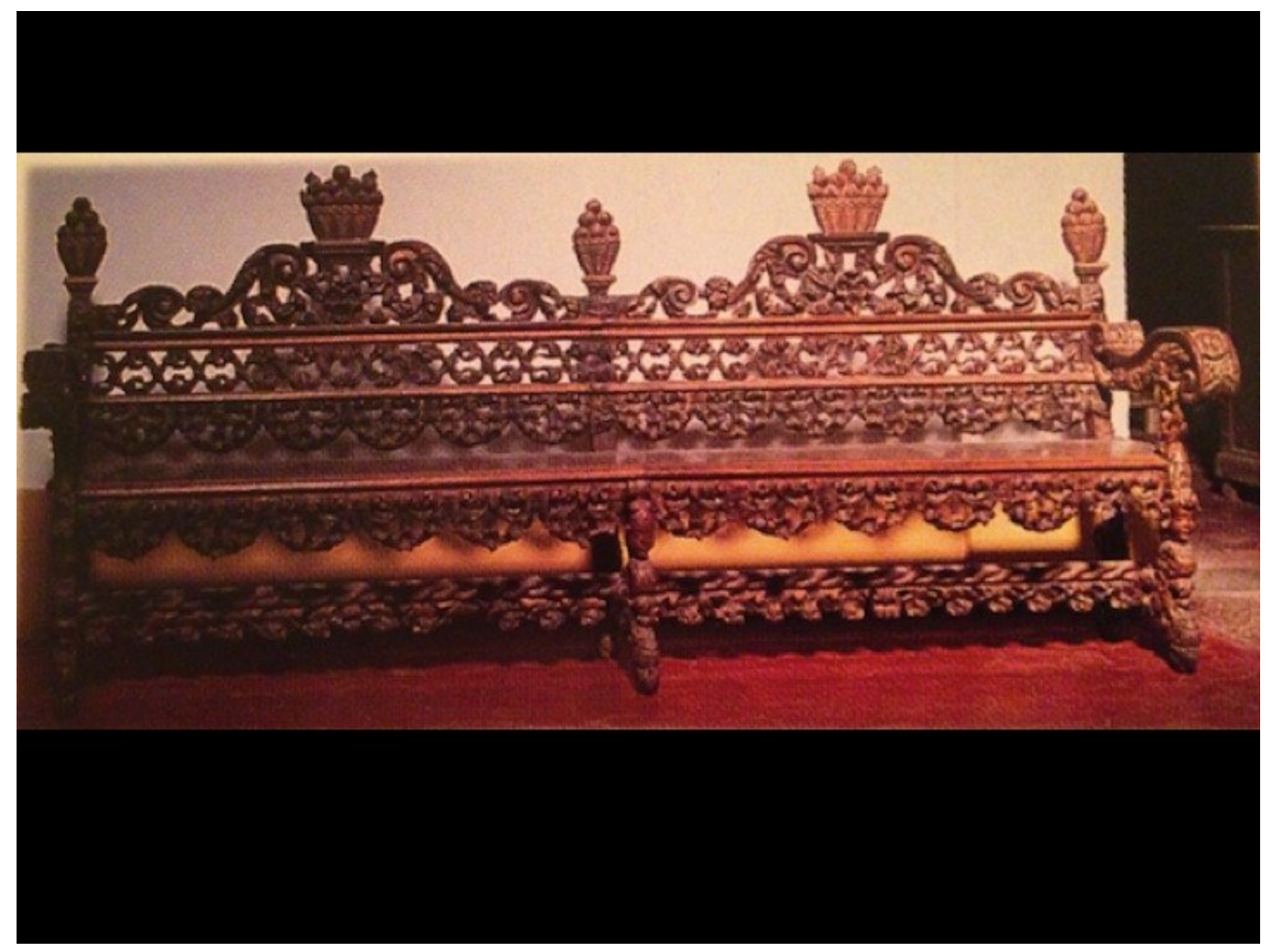

[Fig. 4.13 Reproduction of one wooden bench outside the Camarín] 


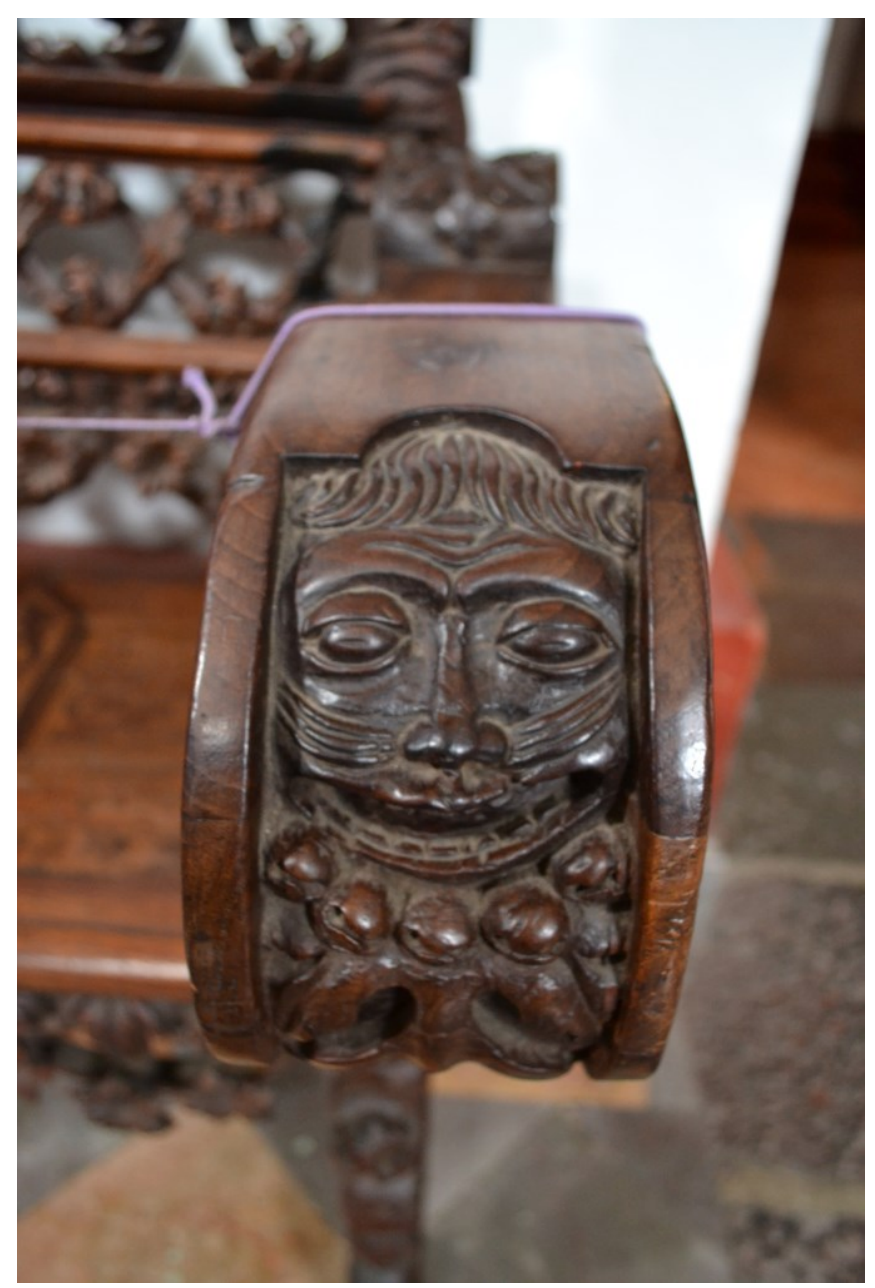

[Fig. 4.14 Francisco Miguel Tlayoltehuanitzi, Detail of wooden bench] 


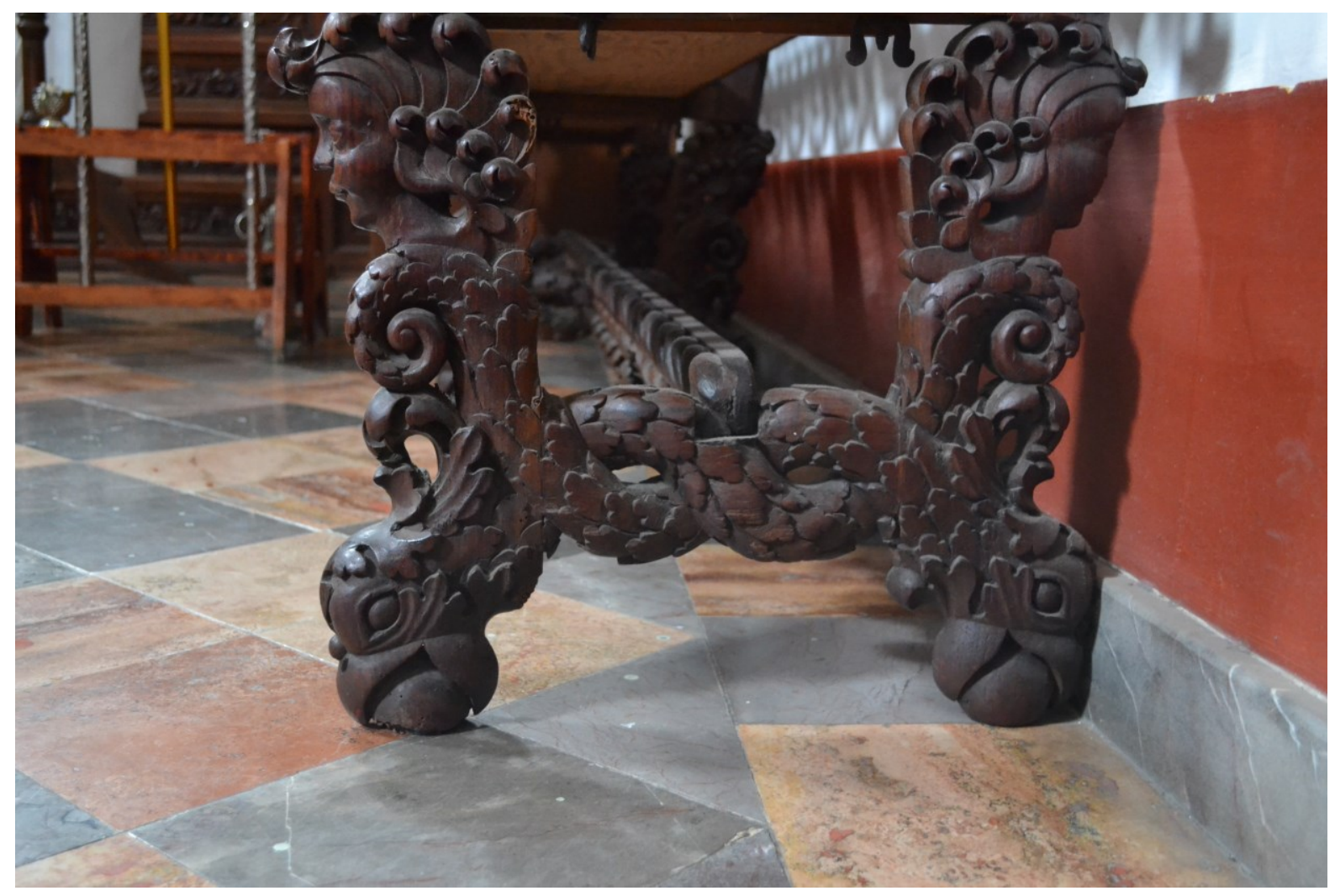

[Fig. 4.15 Francisco Miguel Tlayoltehuanitzi, Detail of wooden bench] 


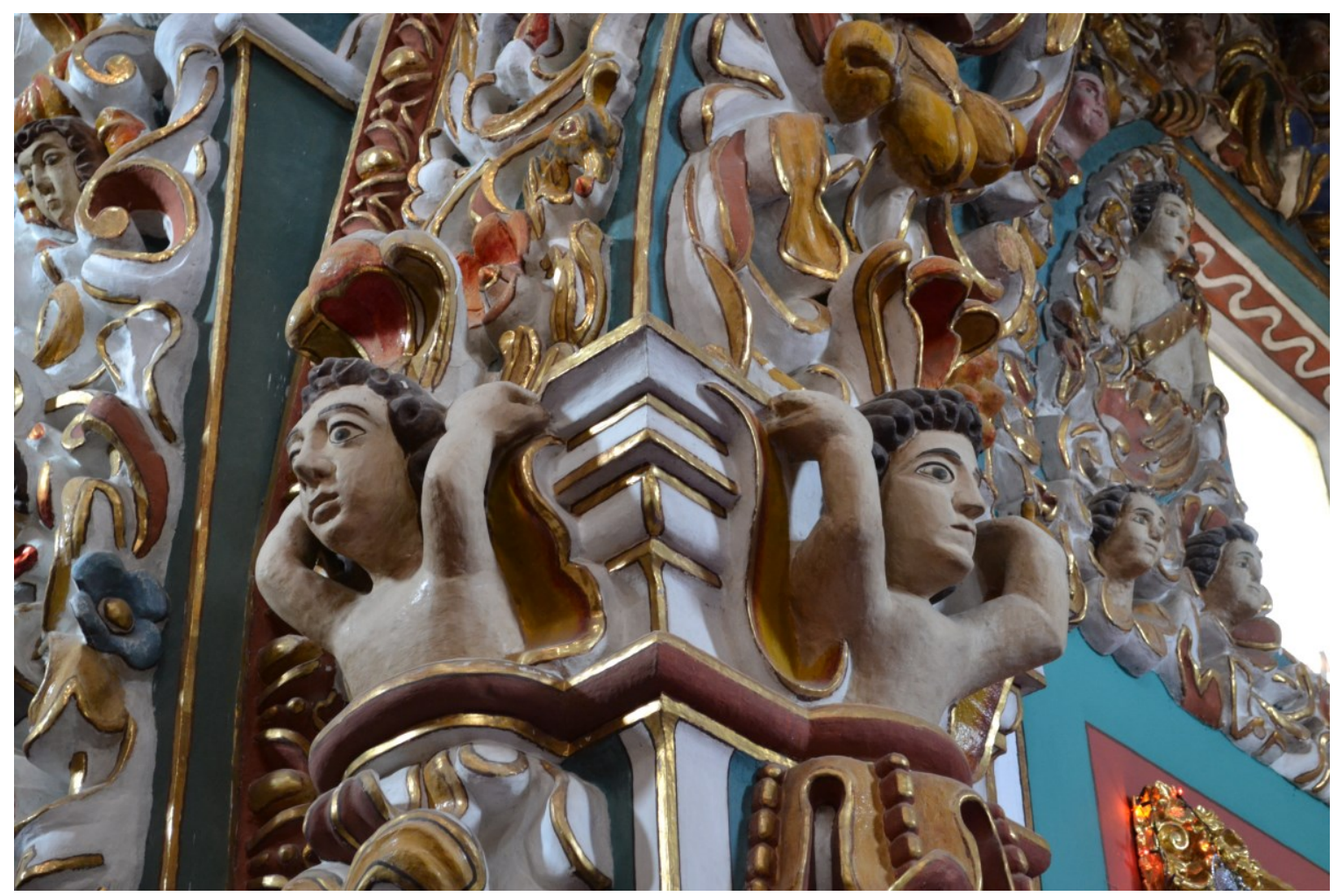

[Fig. 4.16 Detail of the inside of Santa María Tonantzintla, Puebla, Mexico] 


\section{Appendix 2 | Translations}

\section{CHAPTER ONE}

7. "Para Guillermo Tovar se entiende por barroco: "un conjunto de actitudes y manifestaciones artísticas que Occidente crea en la época inmediata a la Reforma Católica...""

29. "Tonantzin, en tanto diosa del maíz, era venerada por los aztecas como la madre protectora quien manifestaba su prodigalidad en flores y frutos que Tláloc, dios de la lluvia hacía crecer y prosperar. Posteriormente es la imagen de la Inmaculada Concepción y bajo el mismo nombre, Tonantzin, quien es reconocida como la madre salvadora aunque sus funciones salvíficas cubren aspectos menos prácticos que los de la alimentación y del sustento. El templo que se le dedica y donde se narra en signos visuales el relato de la coronación está plenamente decorado con flores y frutos cuyo simbolismo alude tanto al cielo (como paraíso), donde la Virgen es coronada, como al Tlalocan, cielo de Tláloc."

55. "el arte tequitui es una interpretación propia y original de los modelos europeos que se copiaban, en las que los indígenas dejan huella de su propia sensibilidad."

56. "Las tradiciones indígenas, aunque no se podían olvidar del todo, fueron también perdiendo fuerza y mezclándose con las tradiciones cristianas para formar un hibridismo religioso todavía practicado en nuestros días por un núcleo importante de la población."

\section{CHAPTER TWO}

71. "El arte barroco que floreció en la Nueva España, como todo el barroco hispanoamericano, constituye una expresión diferenciada del barroco español, del cual deriva."

76. "...de piedra labrada de una efigie de un espantable mounstro la cara muy fea a manera de serpiente con unos colmillos muy grandes, muy encendida y colorada a manera de un encendido fuego en lo qual denotavan el fuego de los rayos y relámpagos que del cielo hechara cuando enbiaba las tempestades y relámpagos".

77. "El templo en que estava este ídolo era alto y hermosamete edificado, tenía para subir a él ochenta gradas al cabo de las quales havía un remanso de doce o catorce pies de ancho y junto a él un aposento ancho y largo de tamaño de una 
sala, la puerta ancha y baja al usso de los edificios de los yndios esta sala estava toda entapicada de mantas galanas labradas a su modo de diversos colores y labores todas llenas de plumas ques lo que conque esta nación adornan sus aderecos y atavíos."

\section{CHAPTER THREE}

93. "...con que este conocimiento y el que tengo de la piedad de Vuestra Majestad, y cuán grato servicio le haremos sus ministros y prelados en darle motivos a hacer las leyes más eficaces en su ejecución, siendo en su decisión santísimas, me ha obligado a tomar la pluma y ofreceré a Vuestra Majestad, lo más sucintamente que he podido, los motivos que están solicitando a la clemancia de Vuestra Majestad y santo celo de sus ministros, a que animen estas leyes y las vivifiquen con su misma observancia, usando de aquellos medios que más se proporcionen con la materia y el intento, pues no serán dificultosos de hallar."

95. "La comprensión y facilidad para entender cualquier cosa, por dificultosa que sea, es rarísima y en esto yo no dudo que aventajen a todas las naciones y en hacer ellos cosas que los demás no las hacen, ni saben hacer con tal brevedad y sutileza."

96. "Y cuanto a lo práctico y artes mecánicas son habilísimos, como en los oficios de pintores, doradores, carpinteros, albañiles y otros de cantería y arquitectura y no sólo buenos oficiales, sino maestros."

97. "En Atlixco, una de las villas del obispado de la Puebla de los Angeles, llegaron un español y un indio a aprender música de canto de órgano con el maestro de capilla de aquella parroquia y el español en más de dos meses no pudo cantar la música de un papel ni entenderla, y el indio en menos de quince días la cantaba diestramente."

99. "También en la descripción inicial del libro, escrita por el provincial de entonces, fray Diego de Gozorpe, se dice que la Capilla es "una primavera fecunda de flores que brotan rosarios y tarjas frondosas que expresan misteriosos símbolos de sus misterios."

115. "Las flores, y ramos tan bien sacados como nacidos: y todo, por ultimo, tan perfecto, en esta grande Obra del Camarin: que nada le falta, y nada le sobra..." 


\section{CONCLUSION}

126. "El Camarín, que ha muchos años, que se acabó, sin que ayan acabadeo hasta aora, ni los mayores Maestros de admirarle; ni los Oficiales de mas rumbo de confundirle, atonitos, y con razón: porque si las Estatuas mas famosas de Napoles se pusieran en frente del menos pulido rostro, de las muchas, que hazen cata en el Camarín, se taparan las suyas de verguenza." 


\section{Bibliography}

Aguilar Moreno, José Manuel. "Tequitqui Art of the 16th-Century Mexico: An Expression of Transculturation." PhD Dissertation, University of Texas, 1999.

Anaya Larios, José Rodolfo. Francisco Martínez Gudiño: Un Maestro del Barroco Querétaro. Querétaro: Universidad Autónoma de Querétaro, 2003.

Bailey, Gauvin Alexander. The Andean Hybrid Baroque: Convergent Cultures in the Churches of Colonial Peru. Indiana: University of Notre Dame Press, 2010.

Brescia, Michael Manuel. "The Cultural Politics of Episcopal Power: Juan de Palafox y Mendoza and Tridentine Catholicism in Seventeenth-Century Puebla de los Angeles, Mexico." PhD thesis, University of Arizona, 2002.

Cortés Rocha, Xavier. El Clasicismo en la Arquitectura Mexicana. México: Miguel Ángel Porrúa, 2007.

Curiel, Gustavo. "Nuevas Noticias Sobre un Taller de la Nobleza Indígena." Anales del Instituto de Investigaciones Estéticas de la Universidad Nacional Autónoma de México 15, no. 59 (1998):129-150.

Dacosta Kauffman, Thomas. "La Geografía Artística en América: El Legado de Kubler y sus Límites." Anales del Instituto de Investigaciones Estéticas de la Universidad Nacional Autónoma de México 21, no. $74-75$ (1999):11-27.

De la Maza, Francisco. "La Decoración Simbólica de la Capilla del Rosario de Puebla." Anales del Instituto de Investigaciones Estéticas de la Universidad Nacional Autónoma de México 14, no. 55 (1986):5-29.

Donahue-Wallace. "Picturing Prints in Early Modern New Spain." The Americas 64, no.3 (Jan 2008): 325-349, http://www.jstor.org/stable/30139132.

Durán, Fray Diego. Historia de las Indias de Nueva España y Islas de Tierra Firme. Vol.1. México: Impresoras Ignacio Escalante, 1880.

Fernández, María. Cosmopolitanism in Mexican Visual Culture. Austin: University of Texas Press, 2014. 
Fernández, Martha. "El Albañil, El Arquitecto y el Alarife en la Nueva España," Anales del Instituto de Investigaciones Estéticas de la Universidad Nacional Autónoma de México 14, no. 55 (1986):49-68.

Fernández, Martha. Estudios Sobre el Simbolimo en la Arquitectura Novohispana. Mexico City: UNAM, 2011.

Galí Boadella, Montserrat. "Juan de Palafox y el Arte: Pintores, Arquitectos y Otros Artífices al Servicio de Juan de Palafox." In Palafox: Iglesia, Cultura y Estado en el Siglo XVII, Congreso Internacional, IV Centenario del Nacimiento de Don Juan Palafox y Mendoza, edited by Congreso Internacional Palafox, 367-381. Pamplona, Spain: Universidad de Navarra, 2001.

García, Viridiana Vera. Inventario del Archivo Parroquial de Nuestra Señora de Ocotlán, Tlaxcala. México: Apoyo al Desrrollo de Archivos y Bibliotecas de México, A.C., 2008.

Guido, Ángel. "America's Relation to Europe in the Arts." In Baroque New Worlds: Representation, Transculturation, Counterconquest, edited by Lois Parkinson Zamora and Monika Kaup, 183-197. Durham, NC: Duke University Press, 2010.

Herníquez Ureña, Pedro. "Baroque in America." In Baroque New Worlds: Representation, Transculturation, Counterconquest, edited by Lois Parkinson Zamora and Monika Kaup, 200-208. Durham, NC: Duke University Press, 2010.

Kalpan E, Marina. "Ocotlán y la Estética del Barroco." Anales del Instituto de Investigaciones Estéticas de la Universidad Nacional Autónoma de México 14, no. 56 (1986):53-76.

Kraidy, Marwan M. Hybridity, or the Cultural Logic of Globalization. Philadelphia: Temple University Press, 2005.

Kubler, George. "Indianism, Mestizaje, and Indigenismo as Classical, Medieval, and Modern Traditions in Latin America." In Studies in Ancient American and European Art: The Collected Essays of George Kubler, edited by Thomas F. Reese, 75-80. Massachussetts: Yale University Press, 1985. 
Loayzaga, Manuel de. Milagrosissima Imágen de Nuestra Señora de Occotlán. Puebla: Imprenta de la Viuda de Miguel de Ortega, en el Portal de las Flores, 1745.

MacGregor, Luis. El Plateresco en México. México: Editorial Porrúa, 1954.

Manrique, Jorge Alberto. "La Estampa Como Fuente de Arte en la Nueva España." Anales del Instituto de Investigaciones Estéticas de la Universidad Nacional Autónoma de México 13-1, no. 50 (1982):55-60.

Neumeyer, Alfred. "The Indian Contribution to Architectural Decoration in Spanish Colonial America." The Art Bulletin 30, no. 2 (1948):104-121.

Nussbaum, Felicity. A. The Global Eighteenth Century. Baltimore: The Johns Hopkins University Press, 2003.

Palafox y Mendoza, Juan. De la Naturaleza y Virtudes del Indio. 2nd Ed. Puebla: Gobierno del Estado de Puebla; Secretaría de Cultura, 1989.

Papastergiadis, Nikos. "Tracing Hybridity in Theory." In Debating Cultural Hybridity: Multi-Cultural Identities and the Politics of Anti-Racism, edited by Tariq Modood et al., 257-281. London; New Jersey: Zed Books, 1997.

Pasztory, Esther. "Aesthetics and Pre-Columbian Art." RES no. 29/30 (1996): 319325.

Pérez Morera, Jesús. "Formas y Expresiones de la Platería Barroca Poblana: Repertorio Decorativo, Técnicas y Topologías." Anales del Instituto de Investigaciones Estéticas de la Universidad Nacional Autónoma de México 34, no. 100 (2012):25-38.

Prampolini, Ida Rodríguez. "El Arte Indígena y los Cronistas de la Nueva España." Anales del Instituto de Investigaciones Estéticas de la Universidad Nacional Autónoma de México 5, no. 17 (1949):5-16.

Pratt, Mary Louise. Imperial Eyes: Travel Writing and Transculturation. 2nd ed. London; New York: Routledge, 2008.

Reyes-Valerio, Constantino. Arte Indiocristiano: Escultura en el Siglo XVI en México. México: Instituto Nacional de Antropología e Historia, 1978. 
Reyes-Valerio, Constantino. "El Arte Indocristiano o Tequitqui." In Historia del Arte Mexicano, edited by Jorge Alberto Manrique, 707-725. Querétaro, Méx: Salvat Mexicana de Ediciones, 1982.

Romero de Terreros, Manuel. Grabados y Grabadores en la Nueva España. México

D.F.: Talleres Gráficos de la Compañía Editora y Librera ARS, S.A., 1948.

Ruiz Moreno, Luisa. "Relatos Míticos en Torno a Tonantzintla." In Mirando al Paraíso, edited by Julio Glockner, 89-102. Puebla: Benemérita Universidad Autónoma de Puebla, 1995.

Salcedo Izu, Joaquín. "Palafox, Defensor de los Indios." In Palafox: Iglesia, Cultura y Estado en el Siglo XVII, Congreso Internacional, IV Centenario del Nacimiento de Don Juan Palafox y Mendoza, edited by Congreso Internacional Palafox, 273-282. Pamplona, Spain: Universidad de Navarra, 2001.

Santamaría, Angel T. Nuestra Señora de Ocotlán, Tlaxcala. 3rd ed. Mexico D.F.: Grupo Infagon S.A. de C.V., 2002.

Scott, Michael Richard. "Palafox y Mendoza's Virtudes del Indio as a Deliberative Oration." MA thesis, University of North Carolina at Chapel Hill, 2011.

Toussaint, Manuel. Colonial Art in Mexico. Austin: University of Texas Press, 1967.

Vargaslugo, Elisa. "Juan de Palafox y Mendoza y el Arte Barroco en Puebla." In Palafox: Iglesia, Cultura y Estado en el Siglo XVII, Congreso Internacional, IV Centenario del Nacimiento de Don Juan Palafox y Mendoza, edited by Congreso Internacional Palafox, 353-367. Pamplona, Spain: Universidad de Navarra, 2001.

Vargaslugo, Elisa. México Barroco. Querétaro: Gráficas Monte Albán, S.A. de C.V., 1992.

Weisbach, Werner. Spanish Baroque Art: Three Lectures Delivered at the University of London. Cambridge: University Press, 1941. 